\title{
ELIZABETH MARTOS
}

\section{O CONTEÚDO JURÍDICO DO PRINCÍPIO DA EFICIÊNCIA NO DIREITO FINANCEIRO}

\author{
DisSERTAÇão DE MeSTRAdo \\ Professor Orientador: DOUTOR Estevão Horvath
}

\section{UNIVERSIDADE DE SÃO PAULO}

FACULDADE DE DIREITO

São Paulo

2013 


\title{
ELIZABETH MARTOS
}

\section{O CONTEÚDO JURÍDICO DO PRINCÍPIO DA EFICIÊNCIA NO DIREITO FINANCEIRO}

\author{
Dissertação apresentada ao Departamento de \\ Direito Econômico e Financeiro da Faculdade de \\ Direito da Universidade de São Paulo para \\ obtenção do título de mestre
}

Orientador: Professor Dr. Estevão Horvath

\section{UNIVERSIDADE DE SÃO PAULO}

\section{FACULDADE DE DIREITO}

\author{
São Paulo
}

2013 


\author{
UNIVERSIDADE DE SÃO PAULO \\ FACULDADE DE DIREITO \\ DEPARTAMENTO DE PÓS-GRADUAÇão \\ MESTRADO EM DIREITO
}

FOLHA DE AVALIAÇÃO - BANCA EXAMINADORA 


\section{RESUMO}

A lei das financeiras deve se preocupar com o estudo de eficiência no desempenho da atividade financeira do Estado, considerando a dimensão humana no uso de recursos financeiros como instrumento corretor de diferenças sócio-econômicas para reduzir a desigualdade e promover o valor da dignidade humana. Neste contexto, estudamos o conteúdo jurídico do princípio da eficiência de direito público no âmbito do direito financeiro, após a aprovação da Emenda Constitucional n ${ }^{\circ} 19$ de 1998, que alterou o caput do artigo 37 da Constituição Federal do Brasil de 1988, estudando o impacto desse princípio na atividade financeira do Estado uma vez que o significado da eficiência no setor público é a prestação de serviços públicos de melhor qualidade e com melhor custo financeiro. 


\section{RÉSUMÉ}

La loi des finances publiques devrait être concerné par l'étude de l'efficacité dans l'exercice de l'activité financière de l'État, compte tenu de la dimension humaine, l'utilisation des ressources financières tant que courtier d'instrument différences socio-économiques pour réduire les inégalités, promouvoir la valeur de la dignité humain. Dans ce contexte, nous avons étudié le contenu juridique du principe de l'efficacité de droit public en vertu de la loi de finances, après l'adoption de l'amendement constitutionnel n ${ }^{\circ} 19$ de 1998 , qui a modifié le texte introductif de l'article 37 de la Constitution fédérale du Brésil en 1988 étudier l'impact de ce principe sur l'activité financière de l'Etat depuis la signification de l'efficience dans le secteur public est la fourniture de services publics de meilleure qualité et un meilleur rapport coût financier. 


\section{SUMÁRIO}

INTRODUÇÃO.

1. PRINCÍPIO DA EFICIÊNCIA - MATRIZ JURÍDICO-FILOSÓFICA E SUA CONSTRUÇÃO NO DIREITO FINANCEIRO10

1.1. A escola interpretativa da jurisprudência de valores e as premissas contidas na obra Uma Teoria da Justiça de J. Rawls, na biopolítica de Michael de Foucault e sua influência na construção do conteúdo jurídico do princípio da eficiência no direito financeiro

1.2. Fundamento histórico, legal e conteúdo jurídico do princípio da eficiência no direito financeiro.

2. O PRINCÍPIO DA EFICIÊNCIA E A HARMONIA INTERNA DOS VALORES QUE COMPÕEM A EFICIÊNCIA E A HARMONIA EXTERNA COM OS PRINCÍPIOS GERAIS DE DIREITO E DE DIREITO FINANCEIRO............................. 35

2.1. O princípio da eficiência e os direitos fundamentais ................................................... 36

2.2. O princípio da eficiência e a segurança jurídica ................................................................... 41

2.3. O princípio da eficiência e o princípio da legalidade....................................................... 43

2.4. O princípio da eficiência e o princípio da proporcionalidade ………………………...... 53

2.5. A atividade de interpretação e a promoção do princípio da eficiência .............................. 56

2.6. O princípio da eficiência e a discricionariedade administrativa ........................................ 66

3. REFLEXOS DO PRINCÍPIO DA EFICIÊNCIA NA OBTENÇÃO DE RECEITA E NA DESPESA PÚBLICA

3.1. O dever de o Estado planejar a atividade financeira e o princípio da eficiência como parâmetro de qualidade da atividade do Estado obter receita tributária e efetivar despesa pública 69 
5. O PRINCÍPIO DA EFICIÊNCIA NO AMBIENTE NORMATIVO DA ATIVIDADE FINANCEIRA NA ATIVIDADE FINANCEIRA DA DESPESA PÚBLICA................... 87

5.1. O custo dos direitos a capacidade receptiva, a reserva do possível, o mínimo existencial e o principio da eficiência. 94

5.2. A igualdade democrática e o principio da diferença .96

5.3. Intersecção entre os pontos cruciais da teoria da justiça de John Rawls e o gasto público. 97 5.4. O princípio da diferença e a parcela distributiva aos desiguais, proposta para uma análise da capacidade receptiva de recursos públicos

6. O PRINCÍPIO DA EFICIÊNCIA E A TRANSPARÊNCIA FISCAL NO EXERCÍCIO DA ATIVIDADE FINANCEIRA DO ESTADO..................................... 103

7. A QUESTÃO dA AFERIÇÃO CONCRETA DO RESPEITO AO PRINCÍPIO DE EFICIÊNCIA NA ATIVIDADE FINANCEIRA DO ESTADO .................................... 107 


\section{INTRODUÇÃO}

O Direito Financeiro deve se preocupar com o estudo da eficiência no exercício da atividade financeira considerando a dimensão humana de sua prática (finalidade), que se concretiza por meio de captação de recursos (atividade tributária) e pela efetivação da despesa como instrumento corretor das diferenças socioeconômicas objetivando a redução de desigualdade (art. $3^{\circ}$, inciso II, CF) promoção do valor dignidade da Pessoa Humana (artigo $1^{\text {a }}$ inciso II, CF).

A atividade financeira é precedida pela definição das necessidades públicas. Conhecendo-as passam a existir três momentos distintos: a) obtenção de recursos; b) a gestão desses recursos (intermediado pelo orçamento: aplicação, exploração dos bens do Estado) c) o seu do gasto, com o qual se cumpre a previsão orçamentária e se satisfazem as necessidades públicas previstas.

Aproximação ao tema resta cristalizado na brilhante frase de Souto Maior Borges que afirma: "O ordenamento normativo traça os fins; o direito financeiro busca os meios para dar condições a que sejam eles satisfeitos. Busca as receitas, administra-as e gasta os recursos, para cumprir os fins do Estado"1.

Assim o Direito Financeiro também adquire um caráter prescritivo instrumental, cuja uma de suas finalidades precípuas é garantir que os recursos do Estado sejam aplicados eficientemente em ações governamentais e que eles privilegiem o cumprimento dos direitos fundamentais de primeira e segunda geração. Isto não exclui, evidentemente, a proteção e promoção dos demais direitos e garantias previstos Constituição Federal vigente.

A identificação do regime jurídico ao qual se submete o Direito Financeiro, por conseguinte, necessita da identificação dos princípios que regem esse arcabouço normativo. Neste sentido é esclarecedora a lição clássica do ilustre Prof. Geraldo de Camargo Vidigal, em sua obra Fundamentos do Direito Financeiro ${ }^{2}$, que afirma : "os princípios informativos do Direito Financeiro são de natureza lógica: mas há, no princípio chamado 'final', elementos de claro sentido ético". O Poder Público gerencia os recursos que obtém como explorador de seu próprio patrimônio e do patrimônio que consegue angariar junto à coletividade, por meio de sua atividade tributária.

Nesta perspectiva será examinado, nesse estudo, o conteúdo jurídico do princípio da eficiência no direito público, no contexto do Direito Financeiro, depois da aprovação da

\footnotetext{
${ }^{1}$ BORGES, José Souto Maior. Introdução ao direito financeiro. 2a . ed. São Paulo: Max Limonad, 1998. p.27

${ }^{2}$ VIDIGAL, Geraldo de Camargo.Fundamentos do direito financeiro. São Paulo : Revista dos Tribunais, 1973.
} 
Emenda Constitucional $\mathrm{n}^{\circ} 19$ de 1998, que alterou o caput do artigo 37 da Constituição Federal de 1988, ao mesmo tempo em que se procurará estabelecer a relação de coordenação desse princípio com os demais princípios que integram o ordenamento jurídico de direito financeiro. Essa perspectiva é a que, a nosso ver, permite um tratamento em que se atribuirá um viés diferente de aferição do que aquele atribuído usualmente no âmbito do direito administrativo.

Ao lado deste quadro conceitual, serão investigados os impactos de referida construção no contexto da atividade financeira do Estado já que a acepção de eficiência para o setor público possui maior relevância jurídica em razão das causas existenciais do Estado, lugar em que as questões econômicas são uma realidade.

A construção do conteúdo do princípio da eficiência no Direito Financeiro, nesse trabalho considera a matriz teórica filosófica da jurisprudência de valores e também da biopolítica proposta por Michel de Foucault e sob a premissa também dessa visão biopolítica, em que os recursos públicos presentes realizado no orçamento público deveriam ser um instrumento de “fazer viver" à disposição dos soberanos, é que serão avaliados os enunciados legais para elaboração do corpus da dissertação.

O princípio da eficiência possui um adensamento teórico dado o fato de que se concretiza pela obediência a questões valorativas em que se impõe a escolha pública que privilegie os direitos assegurados pela Constituição Federal. As escolhas públicas, por sua vez, são balizadas desde a obtenção da receita , atividade do Estado que encontra limitações ao poder de tributar, e dessas limitações decorrem evidente efeito prático, que se expressa com a regra contida dentro do arcabouço do conteúdo desse princípio, que é a economicidade, viés que apresenta ao debate a finitude dos recursos públicos para o atendimento das necessidades publicas previstas no Ordenamento Jurídico vigente.

O princípio da eficiência pressupõe a escolha racional da percepção de receita e de seu gasto, e, embora esteja dentro do âmbito da decisão política, jamais poderá estar em descompasso com as prioridades definidas pela Constituição Federal, leis esparsas e as consolidações nas leis orçamentárias.

Assim, buscamos estudar a função do comando do princípio eficiência trazido pela Emenda Constitucional nº 19 de 1998 e quais são as consequência dessa positivação já que 
modifica a forma como seus efeitos recobrem o Ordenamento Jurídico Brasileiro, dada a natureza axiológica conferida aos princípios na seara jurídica, visto que princípio da eficiência passou a ser axioma para a interpretação de todas as normas de direito vigentes e vetor para a criação de novos enunciados legais de Direito Financeiro. 


\section{PRINCÍPIO DA EFICIÊNCIA - MATRIZ JURÍDICO-FILOSÓFICA E SUA CONSTRUÇÃO NO DIREITO FINANCEIRO}

1.1. A escola interpretativa da jurisprudência de valores e as premissas contidas na obra Uma Teoria da Justiça de J. Rawls, na biopolítica de Michael de Foucault e sua influência na construção do conteúdo jurídico do princípio da eficiência no direito financeiro

A obra Uma teoria da justiça fora elaborada no contexto histórico da jurisprudência de valores (a partir do inicio do século XX), em que se verificou a existência do Estado de Risco $^{3}$ que na era globalizada se mostrou incapaz de garantir todas as prestações de serviços idealizadas na idealização do Estado Social.

No Estado de Risco a atuação estatal só se justifica em atividades que não podiam ser desempenhadas pela sociedade e nas quais o próprio indivíduo não possa atuar, originariamente, o Estado não possui dinheiro, retirando-o parcimoniosamente dos cidadãos, de acordo com uma regra de justiça, a fim de figurar como intermediário entre cidadãocontribuinte e o cidadão-beneficiário.

Nesse momento histórico, ocorre a chamada "virada kantiana", com resgate do valor justiça, uma reação ao modelo de Kelsen de negação dos valores em duas vertentes: (i) na linha de Ronald Dworkin e Robert Alexy, que busca recuperar a força normativa dos princípios de direito, com todo seu potencial valorativo (distinção entre princípio e regras) e segundo (ii) Chaim Perelman, fundador da retórica moderna, que defende a utilização de recurso aos raciocínios dialéticos e retóricos na aplicação do Direito. Perelman desenvolveu seu trabalho de pesquisa com intuito de verificar se existiria ou não uma racionalidade jurídica nas decisões judiciais. "Justiça", em sua acepção meramente formal, era sinônimo de "igualdade" , ponto de vista adotado por John Rawls.

A jurisprudência dos valores rompe com o positivismo das correntes anteriores, tanto o positivismo normativista quando o positivismo sociológico, e inicia uma reaproximação

\footnotetext{
${ }^{3}$ Para Ricardo Lobo Torres, "o relacionamento entre Estado e Sociedade na fase do liberalismo social permite que se fale em uma sociedade de riscos, característica do Estado Subsidiário ou do Estado Democrático e Social de Direito", que se contrapõe "à sociedade industrial, que dava sustentação ao Estado de Bem-estar Social ou Estado-Providência". Prossegue ao caracterizar a sociedade de riscos com algumas notas relevantes: "a ambivalência, a insegurança e o redesenho do relacionamento entre as atribuições das instituições do Estado e da própria sociedade". (TORRES, Ricardo Lobo. Legalidade tributária e riscos sociais. Revista Dialética de Direito Tributário, São Paulo, n. 59, p. 100-101, ago.2000).

4 " $\mathrm{O}$ ato justo é a correção, rejeição da desigualdade. A regra justa é razão, rejeição de arbitrariedade. O homem justo é consciência, rejeição da desumanidade". (PERELMAN, C. Ética e Direito. Maria Ermantina Galvão (Trad). São Paulo: Martins Fontes, 1996. p.92).
} 
entre o direito e a moral. Entre o direito e a ética, o resgate do ideal de justiça, da teoria dos direitos fundamentais.

A referida corrente de pensamento propõe também a superação da autonomia dos ramos do direito e preconiza a teoria da ordem jurídica, em que afirma a existência de uma ordem racional, baseada em critérios de justiça e que constitua uma unidade, de forma sintética é nesse ambiente que nasce a obra uma teoria da justiça.

Afirma que as instituições são justas quando não fazem distinções arbitrárias entre as pessoas na atribuição dos direitos fundamentais, e quando as leis definem um equilíbrio apropriado entre as reivindicações das vantagens da vida social que sejam conflitantes entre si. A similaridade e diferenças entre as pessoas são importantes na atribuição dos direitos e deveres, e especifica qual é a divisão de vantagens apropriadas;

Segundo o autor, o papel característico das concepções de justiça, conjunto de princípios correlacionados que objetiva identificar as considerações relevantes que determinam esse equilíbrio, em que o equilíbrio é o conceito de justiça, é especificar os direitos e os deveres fundamentais e definir as parcelas distributivas apropriadas.

O modo como determinada concepção de justiça faz a especificação de direitos e deveres fundamentais e define as parcelas distributivas fatalmente influi nos problemas da eficiência, da coordenação e da estabilidade social, indiscutível, portanto, a influência dessas decisões na alocação de recursos para realização das despesas públicas.

Afirma ainda que não podemos, em geral, avaliar a concepção de justiça unicamente por seu papel distributivo, por mais útil que seja esse papel na identificação do conceito de justiça. Assim precisamos levar em conta certa prioridade por ser a mais importante virtude das instituições, ainda assim é verdade que, permanecendo constantes as demais condições, uma concepção de justiça é preferível a outra quando suas consequências mais amplas são mais desejáveis.

O objeto principal da justiça é a estrutura básica da sociedade, ou, mais precisamente, o modo como as principais instituições sociais distribuem os direitos e os deveres fundamentais e determinam a divisão das vantagens decorrentes da cooperação social. As instituições mais importantes, segundo J. Rawls, são: a constituição política; o arranjo social; o arranjo econômico, que conferem a proteção jurídica à liberdade de pensamento,liberdade de consciência, mercados competitivos, propriedade privada dos meios de produção. 
As pessoas são condicionadas em suas perspectivas, esperanças pelo meio socialpolítico-econômico em que nascem (ponto de partida). Assim as instituições sociais favorecem certos pontos de partida mais que outros. Essas desigualdades são muito profundas.

Além de universais, atingem as oportunidades iniciais de vida; contudo, não podem ser justificadas recorrendo-se a ideia de mérito. E a essas desigualdades, supostamente inevitáveis na estrutura básica de qualquer sociedade, que se devem aplicar em primeiro lugar os princípios da justiça social. Esses princípios então regem a escolha de uma constituição política e os elementos principais do sistema econômico social.

A justiça de um arranjo social depende, em essência, de como se atribuem os direitos e os deveres fundamentais e também as oportunidades econômicas e das condições sociais dos diversos setores da sociedade. A concepção de justiça social oferece, em primeiro lugar, um padrão por meio do qual se devem avaliar os aspectos distributivos da estrutura.

O objetivo da teoria é apresentar uma concepção de justiça que generalize e eleve a um nível mais alto de abstração a teoria do contrato social conforme encontrada nas obras de Locke, Rousseau e Kant.

O contrato social originalmente pensado por $J$. Rawls não tem a finalidade de inaugurar determinada sociedade ou de estabelecer uma forma específica de governo e sim a finalidade de assegurar que os princípios de justiça para a estrutura básica da sociedade constituam o objeto do acordo original, de modo a abranger certos princípios morais.

Segundo o autor, houve uma sequência de acordos hipotéticos de sistema geral de normas (escolha de determinada concepção de justiça) que a define. Se as instituições sociais atendem a esses princípios, seus participantes podem afirmar que estão cooperando em condições com as quais concordariam se fossem pessoas livres e iguais cujas relações mútuas fossem equitativas. Todos considerariam seus arranjos sociais como satisfazendo as estipulações que aceitariam em uma situação inicial contendo restrições razoáveis e amplamente aceitas à escolha de princípios.

O reconhecimento geral desse fato seria o fundamento da aceitação pública dos princípios correspondentes da justiça (mas não literal, cada indivíduo ao nascer, se encontra, em determinada situação em alguma sociedade específica). Contudo, uma sociedade que satisfaça os princípios da justiça como equidade aproxima-se tanto quanto possível de ser um sistema voluntário, pois obedece aos princípios com os quais pessoas livres e iguais 
concordariam em circunstâncias equitativas. Nesse sentido, seus membros são autônomos e as obrigações que reconhecem são autoassumidas.

O início da obra Uma Teoria da Justiça é marcado pela exploração dos aspectos intuitivos sobre o conteúdo da teoria da justiça, em que J.Rawls explora o papel da justiça e como os indivíduos devem transportar o valor justiça às instituições, organizações e leis que regem a vida comum, estabelece ainda objeto de sua obra: a justiça social, em que estabelece intuitivamente, ainda, que a injustiça só é tolerável quando necessária para evitar uma injustiça ainda maior.

O autor constrói um núcleo duro do conceito de justiça, que assevera que cada pessoa possui uma inviolabilidade fundada na justiça que nem o bem-estar de toda a sociedade pode desconsiderar. Os direitos e liberdades da cidadania igual são considerados irrevogáveis e devem ser garantidos pela justiça não estão sujeitos a negociações políticas.

A sociedade, na forma exposta pelo autor, com objetivo de validar sua teoria detém características determinadas conforme a seguir, a sociedade é: a associação de pessoas; com certo grau de autossuficiência; com relações mútuas regidas por normas de condutas obrigatórias; comportamento de obediência às normas homogêneas a maior parte do tempo; essas normas também especificam um sistema de cooperação cujo fim e promover o bem dos integrantes; marcada por conflito versus identidade de interesse.

A identidade de interesses se revela na cooperação social e torna possível uma vida melhor para todos do que qualquer um teria se dependesse apenas dos próprios esforços.

O conflito de interesses advém do fato de que ninguém é indiferente no que se refere a como são distribuídos os benefícios maiores produzidos por sua colaboração, pois para atingir seus fins, cada um prefere uma parcela maior a uma parcela menor desses benefícios.

Considerando a existência desse potencial conflito estabelece a função dos princípios da Justiça que devem nortear a escolha entre os diversos modos de organização social que definem essa divisão de vantagens e para selar um acordo acerca das parcelas distributivas apropriadas.

Em apertada síntese, os princípios da justiça social são um modo de atribuir direitos e deveres nas instituições básicas da sociedade e definem a distribuição apropriada dos benefícios e dos encargos da cooperação social. 
A escolha dos princípios de justiça se dá em determinadas condições: a situação inicial contém pressupostos de aceitação geral, igualdade, razoabilidade, equidade, generalidade (os princípios não se aplicam à casuística), desconhecimento de contingenciais (véu de ignorância) que geram discórdias (homem rico versus tributação), inexistência de preconceitos; igualdade na deliberação, liberdade para propor, apresentar razões para aceitação.

A finalidade das condições é representar a igualdade entre os seres humanos como pessoas morais como criaturas que têm a concepção do próprio bem e estão capacitadas a ter senso de justiça.

Junto com o véu de ignorância, que nada mais é que o desconhecimento de determinadas informações que possam interferir no modo de decidir o conteúdo desses princípios que se busca conceituar, essas condições definem os princípios da justiça com aqueles que pessoas racionais interessadas em promover seus interesses aceitariam em condições de igualdade, quando não há ninguém que esteja em vantagem ou desvantagem em razão de contingências naturais ou sociais (posição original).

A posição original é um recurso expositivo que resume o significado dessas condições e nos ajuda a deduzir as consequências. Por outro lado, essa concepção é também uma ideia intuitiva que indica sua própria elaboração, de forma que, conduzidos por ela, somos levados a definir com mais clareza o ponto de vista do qual podemos interpretar melhor as relações morais.

A construção hipotética do autor pressupõe: (i) uma sociedade é bem ordenada; (ii) existência de uma concepção pública de justiça reguladora; ou seja (i.a) todos aceitam e sabem que os outros aceitam os mesmos princípios da justiça; (i.b) as instituições sociais fundamentais atendem, e em geral se sabe que atendem a esses princípios (possibilidade de julgamento em caso de divergência o poder judiciário é quem decide como associação segura).

$\mathrm{O}$ autor reconhece que sociedade bem-ordenada é rara, que o justo e o injusto sempre estão em discussão e há discordância sobre os princípios que definem as condições fundamentais de associação.

Ainda ressalta que existe uma concepção pessoal de justiça e isso resulta na construção de que o conceito de justiça é distinto das diversas concepções de justiça. 
Entendemos que a teoria da justiça na obra de J. Rawls é concebida sob condições artificiais, principalmente as condições nas quais são decididos os princípios da justiça, os aspectos da personalidade dos indivíduos que elegem os princípios que serão vigentes e a forma que se organiza a sociedade que será regida por esses princípios. Esses fatores criam uma distância abissal entre a sociedade real e sua complexidade e a sociedade e ambiente teorizado pelo autor.

Mas acordamos quando o autor afirma que as instituições são justas quando não fazem distinções arbitrárias entre as pessoas na atribuição dos direitos fundamentais, e quando as leis definem um equilíbrio apropriado entre as reivindicações das vantagens da vida social que sejam conflitantes entre si. A similaridade e diferenças entre as pessoas são importantes na atribuição dos direitos e deveres, e especifica qual é a divisão de vantagens apropriadas;

Segundo o autor, o papel característico das concepções de justiça, conjunto de princípios correlacionados que objetiva identificar as considerações relevantes que determinam esse equilíbrio, em que o equilíbrio é o conceito de justiça, é especificar os direitos e os deveres fundamentais, e definir as parcelas distributivas apropriadas.

O modo como determinada concepção de justiça faz a especificação de direitos e deveres fundamentais e define as parcelas distributivas fatalmente influi nos problemas da eficiência, da coordenação e da estabilidade social, indiscutível, portanto, a influência dessas decisões na captação e na alocação de recursos financeiros para realização das despesas públicas.

Afirma ainda que não podemos, em geral, avaliar a concepção de justiça unicamente por seu papel distributivo, por mais útil que seja esse papel na identificação do conceito de justiça. Precisamos levar em conta certa prioridade por ser a mais importante virtude das instituições, ainda assim é verdade que, permanecendo constantes as demais condições, uma concepção de justiça é preferível a outra quando suas consequências mais amplas são mais desejáveis.

Esses princípios então regem a escolha de uma constituição política e os elementos principais do sistema econômico social. A justiça de um arranjo social depende, em essência, de como se atribuem os direitos e os deveres fundamentais e também as oportunidades econômicas e das condições sociais dos diversos setores da sociedade.

A concepção de justiça social oferece em primeiro lugar um padrão por meio do qual se deve avaliar os aspectos distributivos da estrutura. 
O objetivo da teoria é apresentar uma concepção de justiça que generalize e eleve a um nível mais alto de abstração a teoria do contrato social conforme encontrada em Locke, Rousseau e Kant.

O contrato social original, na visão de J. Rawls, não tem a finalidade de inaugurar determinada sociedade ou de estabelecer uma forma específica de governo e sim de que os princípios de justiça para a estrutura básica da sociedade constituem o objeto do acordo original. Mas sim ter em seu teor certos princípios morais.

Segundo o autor, houve sequência de acordos hipotéticos de sistema geral de normas (escolha de determinada concepção de justiça) que a define. Se as instituições sociais atendem a esses princípios, seus participantes podem afirmar que estão cooperando em condições com as quais concordariam se fossem pessoas livres e iguais e iguais cujas relações mútuas fossem equitativas. Todos considerariam seus arranjos sociais como satisfazendo as estipulações que aceitariam em uma situação inicial contendo restrições razoáveis e amplamente aceitas à escolha de princípios.

O reconhecimento geral desse fato seria o fundamento da aceitação pública dos princípios correspondentes da justiça (mas não literal, cada individuo ao nascer, se encontra, em determinada situação em alguma sociedade específica). Contudo, uma sociedade que satisfaça os princípios da justiça como equidade se aproxima tanto quanto possível de ser um sistema voluntário, pois obedece aos princípios com os quais pessoas livres e iguais concordariam em circunstâncias equitativas. Nesse sentido, seus membros são autônomos e as obrigações que reconhecem são autoassumidas.

A posição original concebe a justiça como equidade (natureza contratualista - que impõe na formação a situação original hipotética, uma visão contratualista afirma que certos princípios seriam aceitos em uma situação inicial bem definida). Em primeiro lugar, requer igualdade na atribuição de direitos e dos deveres fundamentais. Em segundo lugar, afirma que as desigualdades sociais e econômicas somente serão justas se resultarem em vantagens recompensadoras para todos e, em especial, para os membros menos favorecidos da sociedade. Ambas as afirmações funcionam como neutralizadores aos acidentes da dotação natural e das contingências das circunstancias sociais.

O uso do termo contratualista expressa à ideia de que os princípios da justiça podem ser concebidos como princípios que seriam escolhidos por pessoas racionais e que, assim, é possível explicar e justificar as concepções de justiça. 
Uma concepção de justiça pode ser mais razoável e justificável que outra, se as pessoas racionais na situação inicial escolheram os princípios para o papel da justiça.

Ao encontro da valorização do indivíduo em que as principais instituições sociais distribuem os direitos e os deveres fundamentais e determinam a divisão das vantagens decorrentes da cooperação social, temos o surgimento da ideia de biopolítica promovida por Michael de Foucault.

O termo biopolítica fora citado de forma inédita, e com o sentido que adotamos, em palestra proferida por Michael de Foucault no Rio de Janeiro, intitulada O Nascimento da Medicina Social, e devidamente desenvolvido nas obras: A Vontade de Saber (1976) e, depois, com os cursos ministrados no Collège de France, intitulados Em Defesa da Sociedade (1975-1976), Segurança, Território e População (1977-1978) e Nascimento da Biopolítica (1978-1979), em que o autor concede relevo e amplitude ao termo.

Após toda a obra científica produzida a respeito da teoria sobre o poder, de forma sintética para Foucault, a partir do século XVIII, o Ocidente admitiu uma profunda transformação nos mecanismos de poder, isso porque o poder de soberania, o direito de causar a morte ou de deixar viver, fora substituído por "um poder que gera a vida e a faz se ordenar em função de seus reclamos", , e para Foucault, o século XVIII, marca o processo de entrada da proteção da vida como protagonista na história, o que quer significar a entrada dos fenômenos próprios à vida humana na pauta do saber e nos cálculos do poder. Desse modo, os processos relacionados à vida humana começam a ser levados em consideração por mecanismos de poder e de saber que tentam controlá-los e modificá-los. Afirma Foucault:

\footnotetext{
O homem ocidental aprende pouco a pouco o que é ser uma espécie viva num mundo vivo, ter um corpo, condições de existência, probabilidade de vida, saúde individual e coletiva, forças que se podem modificar, e um espaço em que se pode reparti-las de modo ótimo. Pela primeira vez na história, sem dúvida, o biológico reflete-se no político; o fato de viver não é mais esse sustentáculo inacessível que só emerge de tempos em tempos, no acaso da morte e de sua fatalidade: cai, em parte, no campo de controle do saber e de intervenção do poder ${ }^{6}$.
}

A vida passa a ser o ponto central do controle do saber e da intervenção do poder, mais do que a ameaça da morte, tenho em vista que o poder pode apropriar-se dos processos

\footnotetext{
${ }_{6}^{5}$ FOUCAULT, Michel. História da Sexualidade I: A Vontade de Saber. Rio de Janeiro: Graal, 1988. p.128.

${ }^{6}$ Idem, ibidem. p.134.
} 
biológicos para controlá-los e eventualmente modificá-los. Assim para Foucault, a descrição dessa novel visão pode ser observada abaixo:

\begin{abstract}
Se pudéssemos chamar de 'bio-história' as pressões por meio das quais os movimentos da vida e os processos da história interferem entre si, deveríamos falar de 'biopolítica' para designar o que faz com que a vida e seus mecanismos entrem no domínio dos cálculos explícitos, e faz do poder-saber um agente de transformação da vida humana ${ }^{7}$. (grifos do autor)
\end{abstract}

O termo apropriado encontrado pelo autor para esse fenômeno foi a expressão biopolítica, isso porque são desenvolvidos novos instrumentos de saber , que funcionam "a serviço" do poder. Esses, em sua essência, destinam-se ao controle da própria espécie; e a população adquire um novo conceito que se constrói para dar conta de uma dimensão coletiva é esse "novo corpo: corpo múltiplo, corpo com inúmeras cabeças, se "não infinito pelo menos necessariamente numerável",8

A biopolítica se ocupa também dos processos biológicos relacionados ao homemespécie, estabelecendo sobre os mesmos uma espécie de regulamentação. E, para compreender e conhecer melhor esse corpo, é preciso ultrapassar o campo da constatação (descrição e quantificação - por exemplo, em termos de nascimento e de mortes, de fecundidade, de morbidade, de longevidade, de migração, de criminalidade, etc.), mas essencialmente transformar essas informações em conhecimento, ao analisar tais descrições e quantidades, combinando-as, comparando-as e, sempre que possível, prevendo seu futuro por meio do passado.

A produção de múltiplos saberes como a Estatística, a Demografia e a Medicina Sanitária, são exemplos da evolução na forma de tratar dados de mera constatação para transformá-los em conhecimento. Para Foucault, o "limiar de modernidade biológica" de uma sociedade acontece exatamente no momento em que a espécie humana se torna player no jogo de estratégias políticas de um Estado. "O homem", diz ele, "durante muito tempo, permaneceu o que era para Aristóteles: um animal vivo e, além disso, capaz de existência política; o homem moderno é um animal, em cuja política, sua vida de ser vivo está em questão"9.

\footnotetext{
${ }^{7}$ FOUCAULT, Michel. História da Sexualidade I: A Vontade de Saber. Rio de Janeiro: Graal, 1988

${ }^{8}$ FOUCAULT, Michel. Em Defesa da Sociedade. São Paulo: Martins Fontes, 1999. p. 279.
}

${ }^{9}$ FOUCAULT, Michel. História da Sexualidade 1: A Vontade de Saber. Rio de Janeiro: Graal, 1988. p.134. 
Uma das consequências práticas do poder cujo objetivo é promover a vida é a necessidade de criação de mecanismos contínuos, reguladores e corretivos. O mecanismo é a norma. É por isso que, como afirma Foucault, "uma sociedade normalizadora é o efeito histórico de uma tecnologia de poder centrada na vida"10.

Em resumo, a biopolítica (sec. XVIII), se afigura como um método de racionalizar os problemas postos à prática governamental pelos fenômenos próprios de um conjunto de vivos que constituem uma população. Avançando em sua teoria com a publicação de Nascimento da Biopolítica (1978-1979), Foucault busca analisar as novas formas de controle biopolítico, segundo as posições das economias de mercado, que naquele momento histórico fora influenciado pelo neoliberalismo econômico da Escola de Chicago Foucault chega a conclusão, que sob a influência do neo-liberalismo econômico do pós-guerra, que o homem foi compreendido em termos de homo oeconomicus, isto é, como um ser agente que, estimulado pelas diversas exigências do mercado, busca responder a essas exigências.

O interesse de Foucault, então, dirige-se às diversas formas de controle dos indivíduos e das populações, tal como elas se dão nas modernas economias de mercado. "É preciso", diz Foucault, "governar para o mercado, em vez de governar por causa do mercado"11, e para Foucault, foi essa sociedade de normalização que conseguiu cobrir toda essa superfície que vai do orgânico ao biológico, do corpo à população, mediante a instauração de duas tecnologias, a disciplinar e a regulamentadora ${ }^{12}$.

As ideias expostas na obra de M. Foucault não seguem no sentido de apontar que o poder emana simplesmente do sistema jurídico, ou de qualquer instituição social estatal especifica, mas perpassa pela interação das instituições sociais e das relações sociais individuais, essa relações de interação necessitam da existência de um mecanismo comum, regulador disciplinador, esse mecanismo artificial é a norma, cujo a finalidade principal é privilegiar o "fazer viver".

Nesta perspectiva, temos que em termos de adequação de marco filosófico coadunam a ideia da biopolítica com as vertentes ideológicas da jurisprudência de valores fundada na igualdade, liberdade e justiça social.

\footnotetext{
${ }^{10}$ FOUCAULT, Michel. História da Sexualidade 1: A Vontade de Saber. Rio de Janeiro: Graal, 1988. p.135.

${ }^{11}$ FOUCAULT, Michel. Nascimento da Biopolítica. Curso no Collège de France (1978-1979). São Paulo: Martins Fontes, 2008. p. 64.

${ }^{12}$ FOUCAULT, Michel. Em Defesa da Sociedade. Curso no Collège de France (1975-1976). São Paulo: Martins Fontes, 1999. p. 302.
} 
O homem e a valorização de sua vida, a necessária normatização de suas relações se adequam a premissa adotada, nesse trabalho, pela exposição acima realizada e em tudo sintetizada por Enrique Alonso Garcia, em sua obra que analisa a interpretação constitucional e, nesse ponto, a jurisprudência de valores, suas características e problemas, em que afirma:

Hoy en día, aunque el núcleo de la jurisprudência de los valores sigue afectando a los derechos fundamentales, todo precepto constitucional se ve afectado por esta optica. La garantia institucional afecta a la autonomia local, la maximización de la explotación de la riqueza nacional o el princípio del control parlamentário del gasto público, por ejemplo, son valores que hay que conjugar com otros ${ }^{13}$.

A aproximação desse conjunto de ideias explicitadas, ao tema da atividade financeira do Estado ocorre na medida em que na estrutura demonstrada é possível pensar na concordância do cidadão na repartição da responsabilidade pelo custo dos serviços públicos de modo que se concorda com o modelo tributário adotado pelo Estado (fonte de receitas públicas), respeitada as limitações ao poder de tributar, bem como com a aprovação social do modelo de gasto dessas receitas (despesa pública), desde que implique na manutenção da vida com a promoção do valor igualdade, liberdade e justiça, sendo certo que o princípio da eficiência é um dos fatores que legitima tanto o modelo de tributação como o modelo de gasto público, como restará analisado em capítulos a seguir.

1.2. Fundamento histórico, legal e conteúdo jurídico do princípio da eficiência no direito financeiro

O ordenamento jurídico moderno tem prestigiado a eficiência, e sob o ponto de vista normativo a questão da eficiência administrativa, que, por exemplo, fora tratada pela Constituição Espanhola de 1978, que inseriu esse o conceito já configurado na forma de princípio em seu artigo 103 inciso $\mathrm{I}^{14}$.

\footnotetext{
${ }^{13}$ GARCIA, Enrique Alonso. La Interpretacion de La Constitucion Madrid: Centro de Estudios Constitucionales, 1984. p. 279.

14 Articulo 103 1. La Administración Pública sirve con objetividad los intereses generales y actúa de acuerdo con los princípios de eficacia, jerarquía, descentralización, desconcentración y coordinación, con sometimiento pleno a la ley y al Derecho.
} 
Em contrapartida, o ambiente normativo pátrio tratou desse tema desde 1967, conforme Decreto Lei 200 de $25.05 .1967^{15}$, que estabeleceu diretrizes para a reforma administrativa no governo do presidente Castelo Branco. O referido diploma atribuía a cada Ministro de Estado, integrante da administração Federal, o encargo de assegurar a eficiência administrativa no âmbito de sua respectiva gestão, buscando o aumento da produtividade do servidor administrativo e possibilitando a demissão por desídia e ineficiência.

A Constituição Federal de 1988 já fazia menção à eficiência em seu artigo $84^{16}$, também diplomas infraconstitucionais legais posteriores, exemplificativamente da Lei Federal $\mathrm{n}^{\mathrm{o}} 8.112$ de 11.12.1990, que institui o regime jurídico dos servidores públicos civis da União, das autarquias e das fundações públicas federais, que nos permite identificar a imposição ao servidor público do dever de exercício do cargo com dedicação, prestação e economicidade no uso de insumos e conservação do patrimônio público. Nesse mesmo contexto podemos mencionar a Lei Federal no $8.987 / 95$ e Decreto Federal no $1.171 / 94$.

A Constituição Federal de 1988 já permitia extrair de seu conteúdo o princípio da eficiência, antes mesmo da Emenda Constitucional no 19 de 1998 torná-lo explícito no rol do caput do artigo 37. Isso porque o artigo 70, caput, e 74 ,II, nos permitia já inferir que a Administração Pública direta e indireta está sujeita a controles externo (a ser realizado pelo Poder Legislativo e pelo Tribunal de Contas) e interno (no âmbito de cada poder). Essas duas modalidades de controle se destinam a apurar a legalidade, a eficiência e a eficácia da Administração, avaliando os resultados da gestão orçamentária e a economicidade desta.

A Emenda Constitucional no 19 de 1998 não inovou ao tratar da eficiência como atributo do agir da administração, dado que esse é o esperado ${ }^{17}$, mas ao incluir o princípio da

\footnotetext{
${ }^{15}$ Art. 26. No que se refere à Administração Indireta, a supervisão ministerial visará a assegurar, essencialmente: I - A realização dos objetivos fixados nos atos de constituição da entidade. II - A harmonia com a política e a programação do Governo no setor de atuação da entidade. III - A eficiência administrativa.

16 Art. 74. Os Poderes Legislativo, Executivo e Judiciário manterão, de forma integrada, sistema de controle interno com a finalidade de: I - avaliar o cumprimento das metas previstas no plano plurianual, a execução dos programas de governo e dos orçamentos da União; II - comprovar a legalidade e avaliar os resultados, quanto à eficácia e eficiência, da gestão orçamentária, financeira e patrimonial nos órgãos e entidades da administração federal, bem como da aplicação de recursos públicos por entidades de direito privado; III - exercer o controle das operações de crédito, avais e garantias, bem como dos direitos e haveres da União; IV - apoiar o controle externo no exercício de sua missão institucional. $\S 1^{\circ}$ Os responsáveis pelo controle interno, ao tomarem conhecimento de qualquer irregularidade ou ilegalidade, dela darão ciência ao Tribunal de Contas da União, sob pena de responsabilidade solidária. $\$ 2^{\circ}$ Qualquer cidadão, partido político, associação ou sindicato é parte legítima para, na forma da lei, denunciar irregularidades ou ilegalidades perante o Tribunal de Contas da União.

17 "É de se perquirir o que muda com a inclusão do princípio da eficiência, pois, ao que se infere, com segurança, à Administração Pública sempre coube agir com eficiência administrativa para seus consentimentos". (FIGUEIREDO, Lucia Valle. Curso de direito administrativo. $4^{\text {a }}$ ed. São Paulo: Malheiros, 2000. p.60).
} 
eficiência no caput do artigo 37 da Constituição Federal de $1998^{18}$, conferiu diferença importante ao positivar o referido princípio da forma que o fez, já que modifica a forma como seus efeitos recobrem o Ordenamento Jurídico Brasileiro, dada a natureza axiológica conferida aos princípios na seara jurídica. Vejamos as lições de Paulo Bonavides ${ }^{19}$ :

\begin{abstract}
Postos no ponto mais alto da escala normativa, eles mesmos, sendo normas, se tornam, doravante, as normas supremas do ordenamento. Servindo de pautas ou critérios por excelência para avaliação de todos os conteúdos normativos, os princípios, desde sua constitucionalização, que é ao mesmo passo positivação no mais alto grau, recebem como instância valorativa máxima categoria constitucional, rodeada de prestígio e da hegemonia que se confere às normas inseridas na Lei das Leis. Com esta relevância adicional os princípios se convertem igualmente em norma normarum, ou seja , a norma das normas.
\end{abstract}

Diante dessa assertiva, temos que o princípio da eficiência passa a ser vetor de interpretação e de criação de enunciados legais, espraiando seus efeitos, inclusive, sobre as enunciados de Direito Financeiro, que tem como objeto de estudo as normas que regem a atividade financeira do Estado, e nas palavras de Alvaro Rodrigues Bereijo a atividade financeira do Estado consiste em:

(..) una actividad dirigida a la obtención de los médios económicos necessários para la satisfaccion de las necessidades colectivas. Esa acción del Estado de detraccion de ingresos de las economías privadas y su posterior empleo o inversión en forma de gasto público, se designa com actividad financiera ${ }^{20}$

O mesmo autor especifica em sua obra que a atividade financeira é apenas uma parte da atividade econômica, e reconhece o caráter multidimensional que a realidade fática lhe confere, dado que da escassez dos recursos financeiros público decorre a necessidade de realização de escolhas públicas, como decisões de autoridades públicas (políticos), cuja única proteção decorre do fato da manifestação da vontade do Estado deve ser feita por lei, suscetível a controle pelo regime jurídico vigente, o que vincula o Estado e seus órgãos a respeitar esse sistema normativo quando da gestão do patrimônio público, efetivação da despesa pública e quando da criação normas de ingressos de receitas. O autor sintetiza a importância do regime jurídico positivado com a assertiva:

\footnotetext{
${ }^{18}$ Artigo 37: A administração pública direta e indireta de qualquer dos Poderes da União, dos Estados, do Distrito Federal e dos Municípios obedecerá aos princípios de legalidade, impessoalidade, moralidade, publicidade e eficiência (...)

${ }^{19}$ BONAVIDES, Paulo. Curso de direito constitucional. $7^{\text {a }}$ ed. São Paulo: Malheiros, 1997. p.261.

${ }^{20}$ BEREIJO, Alvaro Rodrigues. Introduccion Al Estudio Del Derecho Financiero. Madrid: Instituto de Estudios Fiscales, 1976. p. 29.
} 
Cuando la soberania politica se concibe como uma emanacion del Pueblo soberano y la actividae financeira se concibe como uma manifestação del poder financeiro del Estado ( emanción de su soberania política, em la concepción actualmente al uso) se hace posible el sometimiento de los mecanismos de obtención de ingresos y realizacíon de gastos públicos al Derecho. El Derecho objetivo se convierte em la suprema garantia de los ciudadanos, y el fenômeno financeiro será objeto de regulaçión jurídica.Esto no será historicamente posible hasta la aparición de los modernos. Así,pues, la noción de supremacia financeira, esto és,órgano al que dentro del Estado correspem que la suprema facultad decisória em matéria de imposición de tributos y de autorización de gastos, es la que nos permite determinar quién es el sujeto dentro de los distintos órganos del Estado, de la actividad financiera $^{21}$

A atividade financeira do Estado, embora esteja inserida no ambiente normativo da Administração Pública, se distingue da atividade meramente administrativa por razões enumeradas por Pugliese ${ }^{22}$, que sinteticamente podemos elencar como sendo: (i) objeto peculiar das relações que constituem seu dado material, posto que o conteúdo dessas relações respeite a atividade impositiva - por uma obrigação de Direito Público do cidadão frente ao Estado de realizar uma obrigação pecuniária que obedece há um rito procedimental, cujo respeito, possui status de garantia ao cidadão; (ii) existência de institutos característicos e pressupostos: a dívida pública, a administração do tesouro; (iii) o corte especifico de objeto dos enunciados que regulam a obtenção, a gestão e o gasto público, que em muito diferem dos objetos contidos nos enunciados de direito público ou privado.

Alvaro Rodriguez Bereijo esclarece que o Direito Administrativo não se confunde com o Direito Financeiro, ainda que entre eles exista uma relação muito estreita, e ainda que este último esteja inserido no âmbito do primeiro existe evidente autonomia científica, mas em contrapartida entende como Jesus Leguina Villa que se tratam de ramos que admitem a aplicação e integração das normas comuns ${ }^{23}$.

O objeto do Direito Financeiro pátrio é o conjunto de normas que regulam o exercício da atividade financeira, fenômeno uno, expresso pela obtenção das (a) receitas públicas, a realização da (b) despesa pública, organização do (b) orçamento, (c) crédito público.

\footnotetext{
${ }^{21}$ BEREIJO, Alvaro Rodrigues. Introduccion Al Estudio Del Derecho Financiero. Madrid: Instituto de Estudios Fiscales, 1976. p.37 e 38.

${ }^{22}$ PUGLIESE, M. Istituioni di Diritto finanziario. Diritto tributário Cedam, Padova,1932. p.6-7. In BEREIJO, Alvaro Rodrigues. Introduccion Al Estudio Del Derecho Financiero. Madrid: Instituto de Estudios Fiscales, 1976. p. 47.

${ }^{23}$ BEREIJO, Alvaro Rodrigues. Introduccion Al Estudio Del Derecho Financiero. Madrid: Instituto de Estudios Fiscales, 1976. p. 60-61.
} 
As receitas públicas podem ser originárias da exploração do patrimônio público ou decorrente da atividade do Estado tributar (receitas derivadas da exploração do patrimônio particular).

A atividade de obtenção das receitas derivadas (tributárias) possui arcabouço normativo autossuficiente, que é o objeto do Direito Tributário, que esta inserido no âmbito do Direito Financeiro, submetido aos princípios gerais de Direito Público, Direito Administrativo, Direito Financeiro, e por possuir regime jurídico próprio capaz de lhe conferir suficiência.

A atividade financeira pressupõe, de forma geral, o dever de pagar tributo e cumprir as obrigações acessórias tributárias, respeitado os direitos do cidadão face a essa atividade Estatal, conforme bem sintetizado por Aliomar Balieiro nas limitações constitucionais ao poder de tributar.

$\mathrm{Na}$ mesma medida, temos que ao Estado cabe o dever de impor de forma eficiente esse ônus ao cidadão e atender as necessidades públicas, também de forma eficiente.

Com o intuito de alcançar esse objetivo o Estado precisa agir aplicando o princípio da eficiência na :

a) elaboração de política fiscal que pautara a atividade legislativa para a instituição dos tributos e obrigações acessórias tributárias, elaboração de políticas públicas que pautara a definição das necessidades públicas a serem atendidas bem como os fixará os meios (serviços, bens) para atendimento dessas necessidades;

b) criação de meios eficientes de execução desses comandos legais para efetivar a arrecadação da receita tributária e do gasto público;

c) atividade do gasto público deve utilizar eficientemente as prescrições normativas e os recursos financeiros disponíveis para o atendimento das necessidades públicas;

d) disponibilização pelo Estado de meios eficientes de discussão e revisão desse "modo de agir" complexo na atividade financeira de perceber receita pública e realizar o gasto público (legislar e executar as leis), constituindo a garantia do Estado de Democrático de Direito de acesso à eficiente revisão administrativa e judicial dos atos exarados pelos poderes Legistativo, Executivo e Judiciário. Cumpre mencionar que se trata de garantia constitucional, no entanto, a revisão administrativa pode se dar pela via do controle dos próprios atos, etapa anterior à litigância (administrativa ou judicial). Do ponto de vista do 
princípio da eficiência impende ressaltar que a revisão, seja ela administrativa ou judicial, decorre da ineficiência em qualquer fase das ações Estatais, sendo certo que em relação à revisão administrativa ou judicial resta afastada e ineficiência Estatal em qualquer das fases nos casos de evidente má-fe do administrado no manejo da via revisional para a discussão de seus direitos materiais ou formais.

Tecidas essas considerações, faremos algumas considerações sobre o tema dos princípios de direito.

O conceito de princípio encontra extensa produção científica no âmbito da dogmática jurídica, mas dentre eles optamos pela proposição de Humberto Ávila que o define " como norma-do-que-deve-ser", referindo a um "estado ideal de coisas" ${ }^{24}$ :

Os princípios são normas imediatamente finalísticas, primariamente prospectivas e com pretensão de complementaridade e de parcialidade, para cuja aplicação se demanda uma avaliação de correlação entre o estado de coisas a ser promovido e os efeitos decorrentes da conduta havida como necessária à sua promoção ${ }^{25}$.

O grau de abstração das normas de natureza principiológica é necessário para possibilitar o alcance maior de enunciados de modo que possibilite à atribuição de sentido às comandos normativos, de modo que o princípio exerça uma função integrativa no sistema ao qual pertence, estabeleça relações de coordenação e conferirá concretude e exequibilidade às normas-regras.

Segundo Robert Alexy, essa feição do princípio decorre do fato de que os princípios são mandamentos de otimização ${ }^{26}$, tomando como ponto de partida a teoria da diferenciação de princípios e regras formuladas por Ronald Dworkin, da qual discorda em partes, descreve a referida diferença: “O ponto decisivo na distinção entre regras e princípios é que princípios são normas que ordenam que algo seja realizado na maior medida possível dentro das possibilidades jurídicas e fáticas existentes"27.

A diferença decorre da qualidade valorativa do princípio em relação à regra, em oposição à diferença unicamente de grau, baseada na generalidade defendida pelos autores

\footnotetext{
${ }^{24}$ ÁVILA, Humberto. Teoria dos Princípios - da definição à aplicação dos princípios jurídicos. $5^{\mathrm{a}}$ ed. São Paulo: Malheiros, 2006. p.72.

${ }^{25}$ Idem, ibidem. p.78-79.

${ }^{26}$ Princípios são, por conseguinte, mandados de otimização, que são caracterizados por poderem ser satisfeitos em graus variados e pelo fato de que a medida devida de sua satisfação não depende somente das possibilidades fáticas, mas também das possibilidades jurídicas. O âmbito das possibilidades jurídicos é determinado pelos princípios e regras colidentes. (ALEXY, Robert. Teoria dos direitos fundamentais. São Paulo: Malheiros Editores, 2008. p.90).

${ }^{27}$ Idem, ibidem.
} 
clássicos, com os princípios se caracterizando como mandamentos de otimização. E afirma que as regras ou são satisfeitas ou não:

Se uma regra vale, então, deve se fazer exatamente aquilo que ela exige; nem mais, nem menos. Regras contêm, portanto, determinações no âmbito daquilo que é fática e juridicamente possível. Isso significa que a distinção entre regras e princípios é uma distinção qualitativa, e não uma distinção de $\operatorname{grau}^{28}$

Desse modo, as regras possuem caráter menos valorativo, menos abstrato e são destituídas do predicado de integrar, dada sua evidente natureza excludente, o autor ainda aponta que havendo conflito de regras, ou no enunciado de uma regra é introduzido um juízo de exceção ou uma das regras será invalidada, vejamos:

Não importa a forma como sejam fundamentados, não é possível que dois juízos concretos de dever-ser contraditórios entre si sejam válidos. Em um determinado caso, se se constata a aplicabilidade de duas regras com consequências jurídicas concretas contraditórias entre si, e essa contradição não pode ser eliminada por meio da introdução de uma cláusula de exceção, então pelo menos uma das regras deve ser declarada inválida ${ }^{29}$.

Cumpre mencionar a densidade normativa do princípio, embora o necessário grau de abstração jamais possa distanciá-lo de sua efetividade:

Os princípios remetem a valores, sendo que valores são mais ou menos prestigiados pelo intérprete segundo uma concepção subjetiva e devem ser avaliados não só segundo sua importância, mas também segundo as possibilidades de concretização ${ }^{30}$.

Robert Alexy, ao tratar da aplicabilidade dos princípios e os possíveis antinomias, aduz:

Se dois princípios colidem - o que ocorre, por exemplo, quando algo é proibido de acordo com um princípio e, de acordo com o outro, permitido -, um dos princípios terá de ceder. Isso não significa, contudo, nem que o princípio cedente deva ser declarado inválido, nem que nele deverá ser introduzida uma cláusula de exceção. $\mathrm{Na}$ verdade, o que ocorre é que um dos princípios tem precedência em face de outro sob determinadas condições. Sob outras condições a questão da precedência pode ser resolvida de forma oposta (...) conflito entre regras ocorrem na dimensão da

\footnotetext{
${ }^{28}$ Idem, ibidem p.91

${ }^{29}$ ALEXY, Robert. Teoria dos direitos fundamentais. São Paulo: Malheiros Editores, 2008. p. 92.

${ }^{30}$ LARENZ, Karl. Metodologia da Ciência do Direito. $3^{a}$ ed. Lisboa: Fundação Calouste Gulbekian, 1997. p. 316
} 
validade, enquanto as colisões entre princípios - visto que só princípios válidos podem colidir - ocorrem, para além dessa dimensão, na dimensão do peso ${ }^{31}$.

O solução da antinomia de princípios passa pelo juízo de ponderação, que na teoria de Alexy tem expressão na ideia de otimização, em que se aplica a máxima da proporcionalidade, com a qual segundo ele, a teoria dos princípios guarda forte relação de pertencialidade. Há assim uma conexão constitutiva pois a natureza dos princípios implica a máxima da proporcionalidade, e essa implica aquela ${ }^{32}$.

A máxima da proporcionalidade é a reunião dos juízos de adequação, da necessidade e da proporcionalidade em sentido estrito. E todos esses princípios expressam a ideia de otimização. Os direitos constitucionais como princípios expressam a idéia de otimização ${ }^{33}$.

Traçadas as premissas a respeito do conceito de princípios passamos a análise do princípio da eficiência, no âmbito do Direito Administrativo e sua expressão no Direito Financeiro.

A doutrina administrativista, ao longo de sua produção científica, construiu diversos conceitos de eficiência, há quem a defina como "a obrigação da Administração Pública de utilizar os recursos públicos do Estado com maior pertinência e adequação possível em prol da sociedade "34, há quem considere como sendo um modo de agir da Administração Pública que determina que aja "de modo rápido e preciso" "35, em contraposição “à lentidão, ao descaso, à negligencia, à omissão"36, Amparo Navarro Faure, doutrinadora espanhola, ao tratar do tema nos traz um panorama da dogmática, elaborada desde a Constituição Espanhola de 1978, considerando a eficiência como princípio constitucional afirma :

Em cuanto a los princípios de eficiencia y economia, la mayoría de los autores interpretan la eficiencia en el sentido de eficácia, es decir, que efetivamente se cumplan las necessidades públicas y la economia como critério que logra la mayor satisfacción al menor coste, con la utilización del menor número de recursos ${ }^{37}$.

\footnotetext{
${ }^{31}$ ALEXY, Robert. Teoria dos direitos fundamentais. São Paulo: Malheiros Editores, 2008. p.93/94.

${ }^{32}$ Idem, ibidem. p. 116 .

${ }^{33}$ Idem, ibidem. p. 135.

${ }^{34}$ MARTINS, Ives Gandra da Silva. Princípio da eficiência em matéria tributária. São Paulo: Revista dos

Tribunais, 2006. p. 31. (Pesquisas Tributárias. Nova série - n. 12).

${ }^{35}$ MEDAUAR, Odete. Direito administrativo moderno. $5^{\mathrm{a}}$ ed. São Paulo: RT, 2001. p.152.

${ }^{36}$ Idem, ibidem.

${ }^{37}$ FAURE, Amparo Navarro. Los principios presupuestarios a la luz de la estabilidad presupuestaria. Revista española de Derecho Financiero. Thonson Civitas. Ediciones Sevilla, p. 507, 2003.
} 
Interessante ressaltar que, no âmbito da ciência da Administração, o termo eficiência e eficácia se distinguem, conforme explicita Idalberto Chiavenato ${ }^{38}$ :

\begin{abstract}
A eficiência significa a correta utilização dos recursos (meios de produção) disponíveis (...) Assim a eficiência esta voltada para a melhor maneira pela qual as coisas devem ser feitas ou executadas (métodos de trabalho), a fim de que os recursos (pessoas, máquinas, matérias primas, etc) sejam aplicados de forma mais racional possível.(...) Eficácia é uma medida normativa do alcance do alcance de resultados, enquanto a eficiência é uma medida normativa da utilização desses recursos nesse processo.
\end{abstract}

Desse modo, entendemos que o conteúdo jurídico do conceito do princípio da eficiência, no contexto da atividade financeira do Estado é: a Administração Pública no exercício da atividade financeira do Estado deve utilizar o melhor método de ação, dentro dos limites da racionalidade e ponderação, afim de que o aparato Estatal, genericamente considerado, possa ser utilizado para que as necessidades públicas sejam atendidas respeitando os direitos e garantias fundamentais do cidadão ao menor custo e ao menor tempo.

A construção do conteúdo jurídico desse comando normativo tem natureza principiológica, e é um comando de otimização que permite a sua aplicação na atividade financeira do Estado de obtenção de receitas, administração do patrimônio Estatal e realização da despesa pública.

Nesse ponto, entendemos que a aplicação do princípio da eficiência em Direito Financeiro é além de ser possível é um imperativo, conforme extraímos das lições de Regis Fernandes de Oliveira:

Em primeiro lugar, o princípio da eficiência não é de direito administrativo, mas de direito financeiro. Sua inserção no art.37 significa que é parte da ação administrativa, mas numa perspectiva financeira. Para que a máquina administrativa funcione e atinja e satisfaça os interesses públicos, é mister que existam recursos para tanto. Dai ser importante, mas se constitui em atividade secundária. Os interesses primários são definidos na Constituição e nas leis.Só que eles, sem arrecadação, ficariam em mero rol de princípios. Há que lhes dar, pois, eficácia ${ }^{39}$.

\footnotetext{
${ }^{38}$ CHIAVENATO, Idalberto. Introdução à teoria da administração. $4^{\mathrm{a}}$ ed. São Paulo: Makron Books, 1993. p. 67

${ }^{39}$ OLIVEIRA, Regis Fernandes de. Curso de direito financeiro. $3^{\text {a }}$ ed. rev.e atualizada. São Paulo: Editora Revista dos Tribunais, 2010. p.104.
} 
Com o objetivo de entender a mecânica da concretização do princípio da eficiência é preciso identificar as manifestações concretas do modo de agir do Estado no exercício da atividade financeira, em tradução livre, que são as descritas por Sainz de Bujanda ${ }^{40}$ :

$1^{\circ} \mathrm{O}$ Império não enquanto fundamento direto do imposto (tributo), mas sim enquanto fundamento da lei fiscal (tributária);

$2^{\circ}$ A lei fiscal (tributária), que obriga tanto a Administração Pública quanto o contribuinte, posto que ambos são partes das relações jurídicas tributária;

$3^{\circ}$ Os atos administrativos de aplicação são normalmente objeto de controle jurisdicional, mediante o exercício de recursos, tanto no âmbito Administrativo quanto judicial;

$4^{\circ} \mathrm{O}$ ciclo completo do exercício da atividade financeira aparece previsto num plano de exercício, articulado formalmente como a Lei Orçamentaria;

$5^{\circ} \mathrm{A}$ ordenação dos gastos e da execução dos pagamentos se produzem com sujeição ao regramento jurídico da Lei Orçamentária e a legislação especial sobre intervenção e contabilidade da Fazenda Pública;

As manifestações concretas descritas são perfeitamente aplicáveis ao ordenamento jurídico pátrio, e coadunando, na forma decomposta, o conteúdo jurídico que formulamos do princípio da eficiência é possível afirmarmos que os modos de ação do Estado estão ligados à manifestação dos poderes em suas funções típicas e atípicas, quais sejam a de legislar, a de executar os comandos legais exarados e a de pacificar conflitos, cujo objeto seja o exercício da atividade financeira.

Assim temos que a elaboração de enunciado prescritivo no sistema jurídico pátrio é o primeiro momento de aplicação do princípio da eficiência, visto que do comando normativo se espera um resultado prático de regulação de condutas ou imposição de valores, sempre de forma inequívoca, diante dessa assertiva temos que necessariamente o ato de redigir enunciados prescritivos esta adstrito a uma tecnologia de produção normativa.

Nesse sentido, parece-nos que andam bem as proposições de Kildare Gonçalves Carvalho, vejamos:

(...) no Brasil, por se tratar de um Estado Federal, o técnico legislativo deverá estar familiarizado com a Constituição Federal, as Constituições Estaduais e as leis orgânicas municipais, com destaque para a Constituição do Estado federado específico, ou a lei orgânica municipal específica, se se tratar de técnico legislativo estadual ou municipal, respectivamente. E mais adiante: são finalmente indispensáveis para a correta redação das leis os conhecimentos dos princípios

\footnotetext{
${ }^{40}$ BUJANDA, Sainz F. La elaboracion corporativa de las disciplinas financieras. Revista de Derecho Financiero y Hacienda Pública, $\mathrm{n}^{\circ}$ 70, p. 625-626. In BEREIJO, Alvaro Rodrigues. Introduccion Al Estudio Del Derecho Financiero. Madrid: Instituto de Estudios Fiscales, 1976. p. 38.
} 
gerais relativos à elaboração das leis, e os de ortografia, gramática, sintaxe e semântica $^{41}$.

O exercício da atividade de produção de leis necessariamente deve respeito às técnicas supramencionadas, como vetores da atividade que se configura na prática como a técnica legislativa, isso em relação não apenas à produção do enunciado prescritivo (aspecto formal), dado o fato de que após a sua idealização, sua escrita ainda precisará passar por um juízo de adequação ao sistema jurídico vigente ao qual pretende pertencer validamente, conforme prelaciona, em sua obra, Gilmar Ferreira Mendes :

(...) há princípios constitucionais que norteiam a formulação das disposições legais, dentre eles o princípio do Estado de Direito e alguns postulados dele derivados, dos quais se podem extrair requisitos que devem orientar a elaboração de atos normativos. O princípio do Estado de Direito impõe ostentem as normas jurídicas atributos como precisão ou determinabilidade, clareza, densidade, visando possibilitar a definição de posições juridicamente protegidas e o controle da legalidade e da ação administrativa. ${ }^{42}$

A técnica legislativa foi positivada pela Lei Complementar $\mathrm{n}^{\circ} 95$, de 26 de fevereiro de 1998, para dar vida ao parágrafo único do artigo 59 da Constituição Federal, e nela foram estabelecidas regras cogentes sobre a elaboração, a redação, a alteração e a consolidação das leis no Brasil.

O respeito aos comados ali expressos como diretrizes devem ser aplicados a todos os atos normativos produzidos, quais sejam as emendas à Constituição, as leis complementares, as leis ordinárias, as leis delegadas, as medidas provisórias, os decretos tanto legislativos quanto executivos, as resoluções e os demais atos de regulamentação expedidos pelos órgãos do Poder Executivo.

O conteúdo das diretrizes determina a forma adequada de estruturação do texto legal bem como cria requisitos definindo-os, e tornando-os cogentes na elaboração do conteúdo do texto normativo que deverão redigidos com clareza, precisão e ordem lógica.

Assim temos, do ponto de vista formal, que os enunciados prescritivos em matéria de Direito Financeiro, para respeitar o princípio da eficiência devem respeitar a técnica legislativa prevista na Lei Complementar 95 de 26 de fevereiro de 1998, e do ponto de vista

\footnotetext{
${ }^{41}$ CARVALHO, Kildare Gonçalves. Técnica Legislativa. $2^{a}$ ed. Belo Horizonte: Del Rey, 2001. p. 59.

${ }^{42}$ MENDES, Gilmar Ferreira. Questões fundamentais de técnica legislativa apud Cláudia F. Rivera Bohn et alii. Elementos de Técnica Legislativa: teoria e prática. Porto Alegre: Sérgio A. Fabris Editor, 1999. p. 45.
} 
valorativo, temos que o enunciado prescritivo que rege a atividade financeira de perceber receita tributária e gasto público deve responder aos valores fundamentais da igualdade, segurança, liberdade e justiça, que norteiam a elaboração dos conteúdos prescritivos bem como sua interpretação ${ }^{43}$, como afirma Bereijo, ao expressar as ideias de Sainz de Bujanda, bem como também de maneira mais concreta deve a atividade de produção legislativa "ponderar sempre os critérios de custo-beneficio, eficácia das medidas versus ônus inerentes financeiros , políticos e sociais $" 44$

Ainda com relação às manifestações de concretude da atividade financeira é necessário em relação à produção legislativa, cujas proposições gerais já traçamos, identificar especificamente na atividade de obtenção de receita tributária e na atividade de despesa pública como se dá a aplicação do princípio da eficiência, não apenas na maneira geral como proposta por Bereijo, mas adentrando as peculiaridades da atividade de arrecadar receitas tributárias e realizar as despesas públicas.

\subsection{Desdobramentos axiológicos do princípio da eficiência}

A construção jurídica do princípio da eficiência no exercício da atividade financeira do Estado, ao que nos parece se dá através de um juízo tríplice ${ }^{45}$ baseado nos conceitos de (i) eficácia ; (ii) efetividade e (ii) eficiência;

Embora encontremos na doutrina administrativista nacional diversas posições distintas e conflitantes a essa ${ }^{46}$, questão natural na dogmática jurídica ${ }^{47}$, mas é nas

\footnotetext{
43 BEREIJO, Alvaro Rodrigues. Introduccion Al Estudio Del Derecho Financiero. Madrid: Instituto de Estudios Fiscales, 1976. p. 38

${ }^{44}$ GOLDSCHIDT, Fábio Brun; VELlOSO, Andrei Pitten. Princípio da Eficiencia em Matéria Tributária. In MARTINS, Ives Gandra (coord.) Princípio da Eficiencia em Matéria Tributária. São Paulo: Editora Revista dos Tribunais, 2006. p. 192, (Pesquisas tributárias. Nova Serie;12).

${ }^{45}$ SANO E FILHO, Hironobu; MONTENEGRO, Mário Jorge França. As técnicas de avaliação da eficiência, eficácia e efetividade na gestão pública e sua relevância para o desenvolvimento social e das ações públicas. Desenvolvimento em Questão: Unijuí , ano 11, n. 22, p. 39, 2013.

46 Alguns autores nacionais tratam como sinônimo os conceitos de eficácia e eficiência, mas preferimos diferenciá-los, por razões científicas, mesmo porque a legislação também faz essa diferenciação conforme podemos observar no artigo $7^{\circ}$ da Lei 11. 653 de 07 de abril 2008: Art. $7^{\circ}$ A gestão do Plano Plurianual observará os princípios de eficiência, eficácia e efetividade e compreenderá a implementação, monitoramento, avaliação e revisão de programas.

47 O termo eficiência não é privativo de nenhuma ciência; é um termo da língua natural, apropriado pelo legislador em sua acepção comum ou com sentido técnico próprio. São os juristas, como agentes ativos no processo de construção do sentido dos signos jurídicos, os responsáveis diretos pela exploração do conteúdo jurídico desse princípio no contexto do ordenamento normativo nacional. (MODESTO, Paulo. Notas para um
} 
proposições de Sandulli contidas no artigo de Edilson Pereira Nobre Júnior, que é parcialmente possível apreender, com maior rigor cientifico, a decomposição do princípio da eficiência que melhor atende às peculiaridades da atividade financeira do Estado, vejamos: (...) passemos, à tarefa árdua por sinal, de demarcação semântica do que se deve
entender por eficieincia. A preocupação, que também permeou a doutrina de fora
dessas plagas, encontrou ressonância na pena de Sandulli que, desvelando o as
diversas ramificaçães do postulado do bom andamento, oferta relevo à
economicidade, a eficácia e a eficiência como categorias distintas e autônomas.
Apos dizer que tais conceitos possuem uma derivação de natureza econômica,
afirma que a economicidade impõe a Administração Pública o dever de
empregar um adequado uso dos recursos à sua disposição. Por sua vez, a
eficácia exprime a necessidade de que a administraçãa ponha em movimento
uma açãa idônea à obtenção de um determinado resultado. Já a eficiência
reclama, com referência à manifestação do sujeito administrativo, o balanço
entre os custos despendidos e as vantagens alcançadas, cabendo a existência de
saldo favorável a estas últimas (balanço e custo-beneficio)

A referida explanação nos concede os elementos primários para desvelarmos esse desdobramento axiológico do princípio da eficiência e nos concede um marco inicial para inferirmos que a eficácia esta relacionada diretamente ao dever de o Estado, para atender as necessidades públicas: (i) planejar e estabelecer metas a serem alcançadas; o (ii) agir concretamente para o alcance dessas metas e (iii) aferir racionalmente a relação entre as metas alcançadas e a metas pretendidas, isso por avaliação de desempenho ou performance.

Nesse ponto, cumpre ressaltar o Estado como ente abstrato não age, mas sim confere poderes ao agente, considerado todo aquele que manifesta um dos poderes do Estado (Legislativo, Executivo ou Judiciário) para agir em seu nome, que faz ou deixa de fazer em virtude da lei, de modo que pratica atos administrativos vinculados a lei, e na possibilidade de aplicação alternativa entre uma lei ou outra há que fazer a escolha da providencia ótima, como nos ensina Celso Antonio "por definição, única e tão somente para proporcionar em cada caso a escolha da providência ótima, isto é, aquela que realize superiormente o interesse público almejado pela lei aplicada"49.

A efetividade é a constatação das transformações ocorridas na realidade após a ação com o objetivo de alcançar as metas pretendidas, sendo certo que as transformações ocorridas

debate sobre o princípio da eficiência. Revista Eletrônica de Direito Administrativo e Econômico, Salvador, $\mathrm{n}^{\circ}$ 10, maio/jun./jul.2007. Disponível em <http://www.direitodoestado.com/revista/REDAE-10-MAIO-2007PAULO\%20MODESTO.pdf $>$. Acesso em 20/10/2012).

${ }^{48}$ NOBRE, Edilson Pereira Júnior. Administração Pública e o Princípio Constitucional da Eficiência. Revista Trimestral de Direito Público, São Paulo: Malheiros, nº.44, p. 75, 2003.

${ }^{49}$ BANDEIRA DE MELLO, Celso Antonio. Curso de direito administrativo. 24 a ed. São Paulo: Malheiros, 1993. p.424. 
na realidade podem ser consideradas positivas (pretendidas) ou negativas (não pretendidas). Em relação às transformações que operam na realidade (reações e resultados que produz) a efetividade esta sujeita ao que Edgar Morin chama de ecologia da ação, em que preleciona que os "efeitos da ação dependem não apenas das intenções do autor, mas também das condições próprias ao meio em que acontece" ${ }^{, 50}$, o que concede especial complexidade ao conteúdo do planejamento e as ações a serem tomadas para o alcance das metas pretendidas.

A eficiência é a obtenção do melhor resultado possível no alcance das metas planejadas e estabelecidas ao menor custo financeiro, portanto, sob esse viés, adquire o sentido de economicidade, conforme expressa previsão do caput do artigo 70 da Constituição Federal, que vincula toda a ação Estatal.

O caráter da economicidade ganha relevo na medida em que o agente público ao exercer a atividade financeira esta também, necessariamente, gerindo bens que integram o patrimônio público, que possui caráter econômico, sendo certo que a res pública, em sua expressão econômica, e por ser o recurso pelo qual se concretiza as finalidades pretendidas pelo ordenamento jurídico deve ser gerida (trinômio geração de receita versus despesa pública versus atendimento das necessidades públicas) respeitando a finitude desses recursos, caráter inerente econômica $^{51}$, vejamos:

\begin{abstract}
A eficiência, muito mais que um pressuposto da assim denominada administração gerencial, constitui dever indeclinável e extensível a todo agente público. Cuida-se da busca contínua do aperfeiçoamento no desempenho das funções públicas que lhe sejam conferidas, tendo como norte a consciência da extrema importância e relevância de cuidar daquilo que é de todos sem ser de ninguém, do bem, do patrimônio, que constitui precisamente a soma dos esforços coletivos que através de gerações vieram a construir um país.
\end{abstract}

A problemática, a respeito da teorização pelo jurista da conjugação desses juízos de eficácia, efetividade e eficiência resta sintetizada nas palavras de Paulo Modesto:

A imposição de atuação eficiente, do ponto de vista jurídico, refere a duas dimensões da atividade administrativa indissociáveis: a. a dimensão da racionalidade e otimização no uso dos meios; b. a dimensão da satisfatoriedade dos resultados da atividade administrativa pública.Não é apenas uma ou outra exigência, mas as duas idéias conjugadas. Eficiência, para fins jurídicos, não é apenas o razoável ou correto aproveitamento dos recursos e meios disponíveis em função dos fins prezados, como

\footnotetext{
${ }^{50}$ MORIN, Edgar. O Método 6 - ÉTICA. Juremir Machado da Silva (Trad.). Porto Alegre:Sulina, 2011, p.41.

${ }^{51}$ CEREIJIDO, Juliano Henrique da Cruz. O Princípio Constitucional da Eficiência, um Enfoque Doutrinário e Multidisciplinar. Revista do Tribunal da União, Brasília, Fórum Administrativo, p. 240, mai/2001.
} 


\begin{abstract}
é corrente entre os economistas e os administradores. A eficiência, para os administradores, é um simples problema de otimização de meios; para o jurista, diz respeito tanto a otimização dos meios quanto a qualidade do agir final. Recorde-se que o administrador público está obrigado a agir tendo como parâmetro o melhor resultado, consultando-se o princípio da proporcionalidade (JUAREZ FREITAS. O Controle dos Atos Administrativos e os Princípios Fundamentais. $2^{\text {a }}$ ed. São Paulo: Malheiros, 1999. p. 85-6) ${ }^{52}$.
\end{abstract}

Contextualizando conteúdo valorativo do princípio da eficiência ao marco teórico adotado, que impõe a realização dos valores segurança, liberdade e justiça conforme a doutrina de Bujanda e Bereijo, bem como para promover os valores da igualdade e justiça social ,como proposto por J. Rawls, pelo exercício da biopolítica, como o poder para "fazer viver" na forma proposta por Michael de Foucault, temos que encontram guarida de aferição na dimensão axiológica da eficácia, especificamente no planejamento, estabelecimento de metas e na ação para concretização dessas metas, dado que a efetividade e a eficiência necessariamente são resultado da ação Estatal.

\footnotetext{
${ }^{52}$ MODESTO, Paulo. Notas para um debate sobre o princípio da eficiência. Revista Eletrônica de Direito Administrativo e Econômico, Salvador, $\mathrm{n}^{\mathrm{o}}$ 10, maio/jun./jul.2007. Disponível em <http://www.direitodoestado.com/revista/REDAE-10-MAIO-2007-PAULO\%20MODESTO.pdf>. p. 09Acesso em $20 / 10 / 2012$
} 


\section{O PRINCÍPIO DA EFICIÊNCIA E A HARMONIA INTERNA DOS VALORES QUE COMPÕEM A EFICIÊNCIA E A HARMONIA EXTERNA COM OS PRINCÍPIOS GERAIS DE DIREITO E DE DIREITO FINANCEIRO}

O princípio da eficiência é princípio positivado pela Constituição Federal, o que quer significar que do ponto de vista sistêmico deve ser vetor de orientação tanto para criação de novos enunciados legais, sejam eles princípios ou regras, como para interpretação dos princípios e das regras vigentes.

A harmonia interna dos conceitos que integram o princípio da eficiência decorre do necessário cumprimento de suas três dimensões, quais sejam da eficácia, efetividade e eficiência, que conforme conceituado não possuem significação oposta, mas sim se coordenam.

Isso porque, mesmo internamente, deve existir uma relação de ponderação entre o grau máximo que se busca atingir de cada dimensão do princípio, sendo certo que, por exemplo, a máxima eficácia muitas vezes não é possível ser realizada com a máxima eficiência ( menor custo econômico).

Isso decorre do fato de que a aferição do princípio da eficiência, em sua dimensão da eficácia, pressupõe que o exercício da atividade financeira do Estado atenda aos objetivos determinados pela Constituição Federal, para a satisfação do bem comum, que em uma sociedade pluralista, nunca será absoluto, mas apenas relativo ${ }^{53}$ dada a multiplicidade de interesses e a impossibilidade de conciliação, bem como considerando a finitude dos recursos públicos que primeiramente faz frente as prioridades estabelecidas.

De outro modo a harmonia externa do princípio da eficiência, considerando a sua contraposição aos demais princípios e regras que integram o ordenamento jurídico pode ocorrer, de forma una, em relação as três dimensões do princípio da eficiência, quais sejam em relação a eficácia, a efetividade e a eficiência, triplamente consideradas ou em um primeiro grau em contraposição apenas a eficácia.

A conclusão acima é possível em razão de considerarmos que é no âmbito da eficácia na atividade de (i) planejar e estabelecer metas a serem alcançadas e do o (ii) agir concretamente para o alcance dessas metas, que também deverá haver o necessário respeito

\footnotetext{
${ }^{53}$ MONCADA, Cabral de. Direito público e eficácia. Lisboa: Pedro Ferreira, 1997. p.09.
} 
aos direitos e garantias fundamentais, inclusive as de realização por prestações positivas (direitos sociais) ,aos demais princípios constitucionais gerais e aqueles aplicáveis ao direito financeiro.

Assim fixação do marco teórico valorativo mostra relevo na solução de antinomia no âmbito, especialmente da eficácia, posto que a partir dessa premissa valorativa é que se resolve as antinomias instaladas pela eleição de planos e metas bem como do agir Estatal, isso pela técnica da ponderação dos princípios, o que não quer impor invalidação do princípio, mas apenas prevalência, conforme as lições de Alexy :

(...) a relevância de um princípio em determinado caso não decorre o resultado seja aquilo que o princípio exige para esse caso. Princípios representam razões que podem ser afastadas por razões antagônicas. A forma pela qual deve ser determinada a relação entre razão e contrarrazão não é algo determinado pelo próprio princípio. Os princípios, portanto, não dispõem da extensão de seu conteúdo em face dos princípios colidentes e das possibilidades fáticas ${ }^{54}$.

Com o auxílio da ponderação de princípios realizadas sob a aplicação do juízo de proporcionalidade que dever ser aferida a adequação, a necessidade e a proporcionalidade em sentido estrito, para então realizar o balanceamento na aplicação dos princípios gerais de direito e de direito financeiro, identificando aquele que mais atende aos direitos fundamentais protegidos pelo sistema normativo.

\subsection{O princípio da eficiência e os direitos fundamentais}

Os direitos de primeira dimensão (civis e políticos) dependem, em regra, do não agir $\operatorname{estatal}^{55}$, já os direitos de segunda dimensão - particularmente os sociais - possuem caráter prestacional e necessitam basicamente da atuação positiva do Estado. É nesse sentido, que José Afonso da Silva aduz que:

(...) os direitos sociais, como dimensão dos direitos fundamentais do homem, são prestações positivas proporcionadas pelo Estado direta ou indiretamente, enunciadas em normas constitucionais, que possibilitam melhores condições de vida aos mais fracos, direitos que tendem a realizar a igualização de situações sociais desiguais ${ }^{56}$.

\footnotetext{
${ }^{54}$ ALEXY, Robert. Teoria dos direitos fundamentais. São Paulo: Malheiros Editores, 2008. p. 104.

${ }^{55}$ Cumpre mencionar que os direitos de primeira dimensão, embora se baseie em uma "não ação Estatal", ainda assim importam em custos financeiros, dada a necessidade da manutenção de uma estrutura que, por exemplo, garanta a reparação desse direito na ocorrência da lesão ou a mera ameaça de lesão, que nesse caso é o Poder Judiciário, que possui estrutura material instalada (predial, aquisição de insumos, contratação de pessoas e serviço, etc). (Nota do autor).

${ }^{56}$ SILVA, José Afonso da. Curso de direito constitucional positivo. São Paulo: Malheiros, 2006. p.286
} 
Os direitos sociais são concebidos sob uma matriz igualitária e possuem o objetivo de impor diretrizes, deveres e tarefas a serem realizadas pelo Estado, com intuito de propiciar aos seres humanos uma melhor qualidade de vida e um nível razoável de dignidade como pressuposto do exercício da liberdade e alcançe do bem-estar.

São pressupostos dos direitos fundamentais, pois eles conjugam as condições materiais necessárias para o exercício de outros direitos. Segundo salienta Sarlet:

\begin{abstract}
A nota distintiva destes direitos é a sua dimensão positiva, uma vez que se cuida não mais de evitar a intervenção do Estado na esfera da liberdade individual, mas, sim, na lapidar formulação de C. Lafer, de propiciar um 'direito de participar do bemestar social'. Não se cuida mais, portanto, de liberdade do e perante o Estado, e sim de liberdade por intermédio do Estado. Os direitos sociais constituem condições imprescindíveis para o efetivo exercício de qualquer outro direito fundamental ${ }^{57}$. (grifos do autor)
\end{abstract}

Os direitos sociais, em sua maioria, estão positivados em nossa Constituição no art. 60: "São direitos sociais a educação, a saúde, o trabalho, a moradia, o lazer, a segurança, a previdência social, a proteção à maternidade e à infância, a assistência aos desamparados, na forma desta Constituição”.

Também estão previsto na Ordem Social (Título VIII), em que se verifica, por exemplo, os direitos sociais relativos à saúde, previdência social, assistência social, educação entre outros.

Do reconhecimento da força normativa potencializada dos direitos fundamentais sociais decorre : a) aceitação da possibilidade de concretização judicial de direitos fundamentais (judicialização de políticas públicas), independentemente de criação de lei pelo Poder Legislativo, como conseqüência do aumento da força normativa da Constituição, da aplicação direta e imediata (máxima efetividade) dos direitos fundamentais $\left(\operatorname{art} .5^{\circ}, \S 1^{\circ}\right.$, da Constituição Federal de 1988) e do reconhecimento da importância do Judiciário na função de guardião dos valores constitucionais; b) criam parametro para ação legislativa que devem "funcionar" em prol da promoção desses direitos sociais fundamentais (vinculação constitucional); c) nova concepção do papel do Judiciário que passar a exercer jurisdição constitucional $^{58}$.

\footnotetext{
${ }^{57}$ SARLET, Ingo Wolfgang. A eficácia dos direitos fundamentais. 6 a . ed. PortoAlegre: Livraria dos Advogados, 2006. p.56-57.

${ }^{58}$ MARMELSTEIN, George. Curso de direitos fundamentais. São Paulo: Atlas, 2008. p. 283.
} 
Aliada à fundamentalidade dos direitos de primeira e segunda geração, temos que o Estado Democrático de Direito implica uma interpretação diferenciada do Direito e não se limita a "enunciar os direitos", mas importa em discutir e (re)discutir o papel da Constituição e do próprio Poder Judiciário, como última instância de interpretação desse instrumento normativo para a caracterização de um "Estado de Direito".

Nesse sentido, Habermas afirma que o Estado Democrático de Direito visa buscar uma nova forma de legitimação:

É que o Direito não somente exige aceitação; não apenas solicita dos seus endereçados reconhecimento de fato, mas também pleiteia merecer reconhecimento. Para a legitimação de um ordenamento estatal, constituído na forma da lei, requerem-se, por isso, todas as fundamentações e construções públicas que resgatarão esse pleito como digno de ser reconhecido ${ }^{59}$.

A questão, conforme demonstrado, indica a tendência moderna dos cidadões exigirem a legitimação do agir Estatal, inclusive no exercício da atividade financeira, que passa pelo enfrentamento da questão da eficiência ${ }^{60}$, conforme bem problematizado por Onofre Alves Batista Junior:

(...) a crise institucional brasileira não abre espaço para soluções que conduzam a um Estado mínimo, porque os administrados não aceitam abrir mão de verem atendidos patamares mímimos de bem-estar economico e social. Efetivamente, a sociedade pluralista reclama um Estado que se amolde ao modelo formatado pela CRFB/88,isto é, um Estado de Direito (Pós-Providencia), de desiderato social,tributário e distribuidor, voltado para a persecução do bem comum de forma otimizada,democrático em seus fundamentos.Nesse sentido, o Estado Democrático de Direito apenas cumpre os objetivos fundamentais da República e atende

\footnotetext{
${ }^{59}$ HABERMAS, J.; HÄBERLE, P. Sobre a legitimação pelos direitos humanos. In: MERLE, J.; MOREIRA, L.(Org). Direito e legitimidade. São Paulo: Landy, 2003. p. 68.

${ }^{60}$ Interessante são os esclarecimentos a respeito da evolução da problemática da questão ética e eficiência administrativa apontada por Tercio Sampaio Ferraz no artigo Ética administrativa num país em desenvolvimento, vejamos: No século XX, porém, o advento do chamado Estado interventor (na vida econômica e na vida social) acabou por alterar a ética da administração. No lugar da ética da legalidade, tanto na versão prussiana como na versão francesa, entra uma ética econômica (Wirtschaftsethik) francamente dominada pelo utilitarismo: a administração como gestora do desenvolvimento social e econômico. Não se trata mais da administração do Estado nas suas funções clássicas — Estado regulador, árbitro, gendarme — mas de uma administração chamada a desempenhar funções muito mais intrusas como protetor e agente econômico direto, que controla como acionista principal ou único uma boa parte de importantes empresas do país. Esta intervenção estatal se realiza por um emaranhado de regras que preveem requisitos e condições para a obtenção de vantagens fiscais, concessões, financiamentos, proteções alfandegárias e que estabelecem procedimentos para os funcionários, aos quais se atribuem competências ainda marcadas pela legalidade, mas carregadas de um forte componente discricionário. O fundamento ético dessa administração intervencionista não é mais a sittliche Gesetzmassigkeit, no sentido de uma ética de convicção, mas a moral da conveniência e da adequação, no sentido de uma ética de resultados (Zweckethik), isto é, a legalidade deixa de ser o núcleo ético da administração, tornando-se apenas um freio que direciona os procedimentos guiados pela exigência de bons resultados. (FERRAZ JUNIOR, Tercio Sampaio. Ética administrativa num país em desenvolvimento. Portal de egoverno, inclusão digital e sociedade do conhecimento. Disponível em <http://www.egov.ufsc.br/portal/sites/default/files/anexos/19169-19170-1-PB.html>. Acesso em 28/11/2013).
} 
legitimamente aos anseios populares se, por um lado,possibilitar a participação democrática dos administrados na Adminsitração Pública e, por outro,proporcionar uma administração pública mais eficiente, que atenda de forma otimizada ao bem comum $^{61}$.

O elemento democrático não se restringe ao voto, ao exercício dos direitos políticos, como possa aparentemente transparecer, temos uma nova forma de interpretar as funções do Estado e do próprio conceito de democracia.

O nível de complexidade e interdependência das frentes de ações do Estado, como Poder Uno, para atender as exigências da sociedade em relação à adequação da produção normativa, atendimento das necessidades públicas, e adequada resposta à pacificação de conflitos coloca em questão o modo como se deve se desenvolver o necessário interrelacionamento das funções Legislativa, Executiva e Judiciária, bem como o desempenho desses papéis de forma a dar feição prática aos conteúdos principiológicos e prescrições normativas constitucionais em relação ao atendimento de determinadas categorias de direito em detrimento a outras.

Assim, é o resultado eficiente das inter-relações dos poderes que a sociedade espera e, detêm o direito de obter, pautado pelo princípio da eficiência, conforme resta delineado pela Constituição Federal, para atendimento dos direitos fundamentais, dos direitos econômicos-sociais e da pacificação de conflitos. Com acerto, Timm aduz que: " a eficiência não é apenas um valor para os economistas, mas que é um dever do Estado, bem como é noção de caráter imperativo que determina a correta utilização dos recursos públicos",62.

O tangencialmente entre os direitos fundamentais e a eficiência é trabalhado por Flavio Galdino :

(...) a eficiência não é inimiga dos direitos fundamentais. Ao contrário de ser uma forma de substituir critérios de justiça por critérios puramente financeiros, a eficiência - adequadamente construída - é um poderoso instrumento de transformação social e proteção dos valores democrático (sic) e dos direitos fundamentais ${ }^{63}$.

\footnotetext{
${ }^{61}$ BATISTA JÚNIOR, Onofre Alves. O Estado Democrático de Direito Pós-Providência Brasileira em busca da eficiência pública e de uma administração pública mais Democrática. Revista Brasileira de Estudos Políticos, Faculdade de Direito da UFMG, Belo Horizonte, n ${ }^{\circ}$ 98, p. 134, jul./dez.2008.

${ }^{62}$ TIMM, Luciano Benetti. Qual a maneira mais eficiente de prover os direitos fundamentais: uma perspectiva de direito e economia? In: SARLET, Ingo Wolfgang; TIMM, Luciano Benetti (Organizadores). Direitos Fundamentais, Orçamento e Reserva do Possível. Porto Alegre: Livraria do Advogado, 2008. p. 55-68.

${ }^{63}$ GALDINO, Flávio. Introdução à Teoria dos Custos dos Direitos: direitos não nascem em árvores. Rio de Janeiro: Lumen Juris, 2005. p. 267
} 
O princípio da eficiência confere a possibilidade de aferição do desempenho da atividade financeira do Estado de arrecadar receitas tributárias para o efetivo dispêndio na promoção de prestação positivas permitindo a fruição dos direitos fundamentais, inclusive os sociais, (despesa pública), visto que essa é a finalidade precípua do Estado.

Além desse aspecto, repisamos o ponto de vista de Regis Fernandes de Oliveira quando afirma que "os interesses primários são definidos na Constituição e nas leis. Só que eles, sem arrecadação, ficariam em mero rol de princípios. Há que lhes dar, pois, eficácia”. Para sintetizar essa afirmação José Casalta Nabais ${ }^{64}$ atribuiu uma relação de implicação que conceitua como "conexão funcional", conclusão que chega ao analisar o dever fundamental de pagar impostos e o dever de fundamental conferido ao cidadão de o Estado atender as necessidades públicas.

Considerando o juízo tríplice que integra o conceito do princípio da eficiência é possível afirmar que existem situações fáticas e no âmbito abstrato da norma, em que é possível verificar a colisão entre o exercício da atividade financeira e o atendimento aos desígnios valorativos contido nas normas que determinam os direitos fundamentais de primeira e segunda geração.

Nesse ponto, impende uma diferenciação da atividade financeira do Estado, no que tange a eficácia. Isso porque ao conceituarmos eficácia e a relacionamos diretamente ao dever do Estado de atender as necessidades públicas, por intermédio do: (i) planejamento e estabelecimento de metas a serem alcançadas; do (ii) agir concretamente para o alcance dessas metas, e considerando, utilizamos uma proposição geral.

Assim, cabe esclarecer que, do ponto de vista do conteúdo e regime jurídico, (i) o planejamento e estabelecimento de metas atividade no exercício da atividade de arrecadar receita de impostos bem como (ii) o regime jurídico do "agir" concretamente para o alcance dessas metas difere do (i) planejamento e estabelecimento de metas no exercício da atividade do gasto público (ii) o regime jurídico do "agir" concretamente para a realização da despesa e alcance dessas metas.

Então considerando que é no plano da eficácia do princípio da eficiência que se opera o juízo de valor e também considerando a diferenciação supramencionada podemos afirmar que dependendo do conteúdo do planejamento e fixação de metas, bem como do modo de ação do Estado para o alcance dessas metas, considerando o regime jurídico

\footnotetext{
${ }^{64}$ NABAIS, José Casalta. O dever fundamental de pagar impostos. Coimbra: Almedina, 1998. p.117-120
} 
peculiar (sistema) da receita tributária e da despesa pública haverá a possibilidade da ocorrência de antinomias dos princípios elegidos como determinantes.

De todo modo ainda que se trate de antinomia no âmbito de valor de direitos fundamentais, será sanável através do sopesamento de princípios aplicáveis, sendo certo que a solução objetivada é aquela que privilegie o princípio constitucional de maior carga valorativa e melhor realize os desígnios constitucionais.

\subsection{O princípio da eficiência e a segurança jurídica}

As relações jurídicas se desenvolveram em um ambiente normativo, o primado da segurança jurídica na visão de Paulo de Barros Carvalho ${ }^{65}$ consiste em: “(...) princípio que coordena o fluxo das interações inter-humanas, no sentido de propagar no seio da comunidade social o sentimento de previsibilidade quanto aos efeitos jurídicos da regulação de condutas".

A segurança é uma necessidade do homem, e com ela se torna possível conduzir, planejar responsavelmente sua vida, busca com grau mínimo de previsibilidade, saber no que confiar e no como se guiar e, amenizando suas ansiedades suas inquietudes, que podem surgir da incerteza nas relações sociais.

No sentido objetivo, a segurança jurídica se manifesta como requisito para regularidade lógica, estrutural e funcional do ordenamento jurídico, expressa nos enunciados e instituições.

No sentido subjetivo, a segurança jurídica, também chamada de princípio da proteção da confiança, expressa a segurança jurídica, não apenas como a certeza do direito, mas sim como a certeza da regulação de condutas, ou seja, como projeção da segurança objetiva nas situações pessoais. Isso se realiza por completo quando o indivíduo tem conhecimento do direito, valendo-se da máxima civil que ninguém pode alegar desconhecer a lei. Devendo-se assegurar a este prévio conhecimento do prescrito, permitido ou proibido, de forma a poder organizar suas condutas presentes e programar suas ações futuras, com objeto jurídico, sob a luz da previsibilidade.

Observamos, na obra de Canotilho ${ }^{66}$, o princípio da segurança jurídica, em seu sentido amplo (objetivo e subjetivo), do seguinte modo:

\footnotetext{
${ }^{65}$ CARVALHO, Paulo de Barros. Curso de Direito Tributário. Sao Paulo: Saraiva, 2000. p.146

${ }^{66}$ CANOTILHO, Jose Joaquim Gomes. Direito Constitucional e Teoria da Constituição. Coimbra: Almedina, 2001. p. 256
} 
(...) $\mathrm{O}$ indivíduo tem do direito poder confiar em que aos seus actos ou às decisões públicas incidentes sobre os seus direitos, posições ou relações jurídicas alicerçados em normas jurídicas vigentes e válidas por esse actos jurídicos deixado pelas autoridades com base nessas normas se ligam aos efeitos jurídicos previstos e prescritos no ordenamento jurídico (...)

Veja-se a opinião de Misabel Abreu Machado, quando trata da atividade tributária: ${ }^{67}$

(...) A segurança jurídica se assenta na legalidade formal e material (especificação conceitual determinante ou tipicidade) consagrados nos artigos $5^{\circ}$ e $150 \mathrm{I}$, da Constituição Federal: reforçados pela exclusividade da lei que concede o subsidio, isenção ou outro benefício fiscal (art. 150, $\$ 6^{\circ}$ da CF/88): minuciosamente explicitadas pelo art. 97 do Código Tributário Nacional; confirmadas e reconfirmadas pela proibição da analogia (art. 108, $\S 1^{\circ}$ ) e, conseqüentemente, das presunções; pela rejeição da interpretação econômica e da cláusula geral antielisiva (art. 109); pelo caráter estritamente vinculado dos atos administrativos de cobrança de tributo (arts. $3^{\circ}$ e 142 ); etc.

O princípio da certeza do direito possibilita e viabiliza o ordenamento jurídico, pois, as relações por eles regidas, são passíveis de serem solucionadas não há conflito insolúvel, a função jurisdicional sempre pacificará os conflitos de forma que as partes (sociedade) tenham certeza do direito aplicável.

O princípio da segurança jurídica possui diversos desdobramentos axiológicos, dos quais destacamos: certeza do direito ${ }^{68}$, irretroatividade da lei, respeito aos direitos adquiridos, respeito ao ato jurídico perfeito, outorga de ampla defesa e contraditório aos acusados em geral, ficção do conhecimento obrigatório da lei, declarações de direitos e garantias individuais, justiça social, devido processo legal, independência do Poder Judiciário, vedação de tribunais de exceção, vedação de julgamentos parciais, definitividade das relações jurídicas.

O princípio da segurança jurídica guarda estreita relação de coordenação com a dimensão da eficácia do princípio da eficiência, isso porque é do viés normativo (criação de

\footnotetext{
${ }^{67}$ MACHADO, Misabel Abreu et al. A elisão tributária e a lei complementar no 104/01. In ROCHA, Valdir Oliveira (coord). O planejamento tributário e a lei complementar 101/01. São Paulo: Dialética, 1998. p.34.

${ }^{68}$ Observações feitas por Santi : Nesses 25 anos de vigência da Constituição Federal de 1988, das 74 emendas feitas à Constituição, 33 cuidaram não só de matéria tributária mas, em sua esmagadora maioria, trataram direta ou indiretamente do aumento da pressão fiscal sobre os contribuintes: criação do IPMF, depois convertida na CPMF, aumento da base de cálculo do PIS/Cofins para receita bruta, autorização da progressividade para o IPTU, instituição da Contribuição de Iluminação Pública, novas hipóteses de incidência para Cide combustíveis, edição do PIS/Cofins importação, exigência do ICMS na importação de pessoa física, aumento da carga tributária nominal pela inauguração do PIS/Cofins não-cumulativo, constitucionalização do malsinado regime da substituição tributária para o ICMS e a oportuna desvinculação de arrecadação de impostos e contribuições sociais da União (DRU). (SANTI, Eurico Diniz de. Segurança jurídica demanda mudança de atitude de auditores. Matéria no Consultor Jurídico. Disponível em <http://www.conjur.com.br/2013-out-10/eurico-santiseguranca-juridica-demanda-mudanca-atitude-auditores>. Acesso em 12/12/2013).
} 
enunciados principiológicos com valores a serem perseguidos ) que decorre o planejamento das políticas públicas e política fiscal, bem como da instrumentalização dessa ação pela edição de leis, com o objetivo de arrecadar tributos, de gerir o patrimônio público e realizar o planejamento da despesa e efetivação do gasto público.

Nesse sentido, entendemos acertada a assertiva de Luís Eduardo Schoueri ${ }^{69}$, que embora a faça no contexto da atividade tributária, traz luz sobre a relação de coordenação dos princípios da eficiência com a segurança jurídica, vejamos:

\begin{abstract}
A previsibilidade poderia ser incluída entre as condições para eficiência econômica. Entretanto, sua importância, ultrapassa a última, pois se relaciona com o valor segurança jurídica.Sem duvida esta permite que os contribuintes possam tomar suas decisões com maior acerto, visto que conhecerão os ônus envolvidos. Nesse sentido, a previsibilidade é instrumento de eficiência. A previsisbilidade relaciona-se, do mesmo modo, com a equidade, no seu valor de justiça.
\end{abstract}

Oportuna, nesse momento, a frase de Rivarol : "O mais difícil em tempos conturbados, não é cumprir o dever, mas identificá-lo”. Esse ponto é crucial, posto que a estabilização e a previsibilidade das relações jurídicas advindas da realização do princípio da segurança jurídica é pressuposto lógico de inferência do princípio da eficiência no contexto da atividade financeira do Estado, seja no âmbito do regime jurídico da percepção de receitas tributárias ou no âmbito do regime jurídico do gasto público.

\title{
2.3. O princípio da eficiência e o princípio da legalidade
}

A teoria do poder desenvolvida por de Michael de Foucault traz interessante visão a respeito de que a lei é uma das consequências práticas do poder para o "fazer viver" são os mecanismos contínuos, reguladores e corretivos. O mecanismo é a norma e "uma sociedade normalizadora é o efeito histórico de uma tecnologia de poder centrada na vida"70.

É nesse contexto que avaliaremos o princípio da legalidade frente o princípio da eficiência no exercício da atividade financeira, posto que no exercício dessa atividade tratamos de : (i) poder ,(ii) normalização e (iii) manutenção da vida pelo atendimento de direitos normatizados, cuja a fruição do direito a vida depende ao acesso aos recursos públicos ${ }^{71}$ que serão utilizados

\footnotetext{
${ }^{69}$ SCHOUERI, Luis Eduardo.Direito Tributário. São Paulo: Saraiva,2011. p.45.

${ }^{70}$ FOUCAULT, Michel. História da Sexualidade 1: A Vontade de Saber. Rio de Janeiro: Graal, 1988. p.135.

${ }^{71}$ OLIVEIRA, Regis Fernandes de. Curso de Direito Financeiro. São Paulo: Revista dos Tribunais, 2011. p. 6869.
} 
para viabilizar o atendimento das necessidades públicas, e é nesse sistema normativo que se encontra (a) o fundamento (a.1) para fruição dos direitos fundamentais (primeira e segunda geração), e (a.2) fundamento para a instituição dos tributos; (b) a limitação que decorre da (b.1) escassez natural dos bens públicos econômicos, (b.2) e da necessidade do atendimento do interesse coletivo em detrimento ao interesse individual, e do (c.3) estabelecimento de direitos e deveres materiais e formais aos integrantes dessa relação que são o Estado e o cidadão que figura nessa relação ora na condição expressa pelo binômio cidadão contribuinte (interesses privados versus interesse público) - cidadão consumidor dos recursos públicos (interesses públicos versus interesses privados ) e por fim (d) a finalidade que é pelo exercício eficiente da atividade financeira atender de forma eficiente as necessidades públicas.

Consideramos os recursos públicos genericamente com sendo os bens tangíveis (materiais) e intangíveis (imateriais) pertencentes ao Estado que possuam expressão econômica, bem como necessidades públicas são aquelas necessidades determinadas pela lei, isso em consonância com a posição de Regis Fernandes de Oliveira:

\footnotetext{
Com o agigantamento do Estado e sua intervenção em quase todas as atividades humanas, cresce a importância do estudo das necessidades públicas. Cuida-se, antes de tudo, para preenchimento de conceito, de uma decisão política. O Estado é quem vai dizer, para usar verbo vicário, no texto constitucional e nas leis posteriores, quais as necessidades que vai encampar como públicas (...) No artigo 21 da Constituição Federal defini-se o que a Constituição deve curar. No art.30, ficam estabelecidas as atribuições do Município e no $\S 1^{\circ}$ do art.25, o que cabe ao Estado realizar. (grifo do autor)
}

A essa posição acrescentamos que, no âmbito do exercício da atividade financeira do Estado e as necessidades públicas, verifica-se que a atividade financeira consiste em obter, criar, gerir e despender o dinheiro indispensável ao atendimento às necessidades públicas, sendo certo que a atividade de criar, gerir e despender se configura como uma necessidade pública por excelência, não em uma relação de hierarquia de necessidades, mas porque é o exercício dessa atividade que viabiliza o atendimento das demais. Todos, em primeiro lugar, necessitamos que o Estado obtenha recursos financeiros eficientemente, administre-os eficientemente e o gaste eficientemente de modo que as necessidades públicas sejam atendidas.

Realizadas essas digressões, temos que a expressão "lei”, de forma sintética, é entendida pela doutrina como sendo consubstanciada em forma escrita, emanada por uma autoridade competente, objeto de processo legislativo previsto pelo direito, que prescreve condutas desejáveis e dotada de sanção. A lei é espécie normativa de caráter geral e abstrato, 
expedido geralmente por pelo poder legislativo, embora em alguns casos emanada pelo pelos demais Poderes como o Executivo, e no âmbito do exercício das funções atípicas de cada poder.

Isso permite entendermos a "lei" em duas acepções: lei em sentido amplo, que seria toda forma de regulamentação por ato normativo do Estado, em que se incluem medidas provisórias, leis delegadas, decretos legislativos, etc.; lei em sentido estrito ou formal, que seriam apenas os atos normativos emanados pelo poder legislativo.

O princípio da legalidade é de curial importância para o direito positivo, de modo que a dogmática jurídica busca analisar os reflexos que a legalidade propaga nos ambiente normativo e seus sistemas (ramos do direito).

Sendo assim nessa busca, diferenciou a legalidade genérica, de outras "legalidades", como a "legalidade penal", a legalidade administrativa, e a legalidade tributária e reserva da lei.

O princípio da legalidade alberga o princípio da reserva legal como uma proteção aos direitos de primeira geração (civis e políticos), visto que busca limitar o poder estatal em face do cidadão, dada a verdadeira relação de Império a que está submetido o cidadão, dado o fato de que ao Estado, ainda que por representação no sistema democrático, e dada atribuição de legislar.

A reserva legal nesse ponto se manifesta com grande expressão no direito público, ou seja, no direito penal, administrativo e tributário, em que se desenvolvem em maior exponencial as relações entre o Estado e o cidadão. A reserva de lei ou reserva legal impõe que determinadas matérias somente poderão ser previstas através de lei (formal), vedando-se o uso de qualquer outra espécie normativa (infralegal).

A Constituição Federal no artigo. 5, II, CF/88 prescreve que o ato que intervenha nos direitos de liberdade ou propriedade individual deve ser veiculado por lei, de modo que é a lei que cria direitos e obrigações.

A reserva legal pode ser identificada em duas gradações em que temos reserva legal absoluta nas situações em que a matéria tratada só pode ser disciplinada por lei produzida pelo poder legislativo, respeitado o procedimento legal necessário e a reserva legal relativa, quando determinada matéria pode ser produzida por atos normativos que embora não 
sejam produzidas poder legislativo, tem força e eficácia de lei. Assim, a reserva de lei relativa se manifesta nas situações em que a lei possa ser regulamentada por atos do executivo dentro dos limites da lei produzida pelo legislativo e nos casos que se aplica, pelos outros poderes. Como, por exemplo, um regulamento que é expedido em razão de um Decreto Presidencial.

Yonne Dolacio de Oliveira, pautando-se nas lições de Alberto Xavier, descreve a reserva relativa de lei formal da seguinte maneira:

\begin{abstract}
A reserva relativa de lei formal possibilita uma certa partilha de competência legislativa, para inovar o direito vigente, entre lei e o regulamento. Se a reserva é absoluta, inexiste a partilha de competência, sendo a lei a única fonte, que se estrutura no Poder Legislativo, podendo legitimamente constituir direito novo.
\end{abstract}

Administração Pública, frente ao princípio da legalidade e reserva de lei somente pode agir através de autorização legal, de modo que para a administração pública atuar, é preciso previsão legal.

Essa é a feição que a legalidade assuma nas relações de direito público, que a doutrina denomina de legalidade administrativa; já nas relações de direito privado, o particular pode fazer tudo que a lei não proibir.

Hely Lopes Meirelles aduz:

(...) A legalidade, como princípio de administração, significa que o administrador público está em toda atividade funcional, sujeito aos mandamentos da lei, e às exigências do bem-comum, e deles não se pode afastar ou desviar, sob pena de praticar ato inválido e expor-se à responsabilidade disciplinar, civil e criminal, conforme o caso. A eficácia de toda atividade administrativa está condicionada ao atendimento da lei. $\mathrm{Na}$ administração Pública, não há liberdade nem vontade pessoal. Enquanto na administração particular é lícito fazer tudo que a lei não proíbe, na Administração Pública só é permitido fazer o que a lei autoriza. A lei para o particular, significa "pode fazer assim"; para o administrador "deve fazer assim". As leis administrativas são, normalmente, de ordem pública, e seus preceitos não podem ser descumpridos, nem mesmo por acordo ou vontade conjunta de seus aplicadores e destinatários, uma vez que contém verdadeiros poderes-deveres, irrelegáveis pelos agentes públicos. Por outras palavras, a natureza da função pública e a finalidade do Estado impedem que seus agentes deixem de exercitar os poderes e de cumprir os deveres que a lei lhes impõe. Tais poderes, conferidos à Administração Pública para serem utilizados em benefício da coletividade, não podem ser renunciados ou descumpridos pelo administrador, sem ofensa ao bemcomum, que é o supremo e único objetivo de toda ação administrativa ${ }^{72}$.

O administrador pode agir nos estritos limites e da lei, fazendo aquilo que ela permite conforme a lição de Celso Antônio Bandeira de Mello:

\footnotetext{
${ }^{72}$ MEIRELLES, Hely Lopes. Direito administrativo brasileiro. 16a ed. São Paulo: Malheiros, 1991. p. 78.
} 
Nos termos do art. $5^{\circ}$, II, 'ninguém será obrigado a fazer ou deixar de fazer alguma coisa senão em virtude de lei'. Aí não se diz 'em virtude de' decreto, regulamento, resolução, portaria ou quejandos. Diz-se 'em virtude de lei'. Logo, a Administração não poderá proibir ou impor comportamento algum a terceiro, salvo se estiver previamente embasada em determinada lei que lhe faculte proibir ou impor algo a quem quer que seja. Vale dizer, não lhe é possível expedir regulamento, instrução, resolução, portaria, ou seja lá que ato for para coartar a liberdade dos administrados (...). Portanto, a função do ato administrativo só poderá ser a de agregar à lei nível de concreção, nunca lhe assistirá instaurar originariamente qualquer cerceio a direitos de terceiros. (grifos do autor)

Para reforçar ainda mais o entendimento deste caráter subalterno da atividade administrativa, basta examinar atentamente o art. 84, IV, da Lei Magna. De acordo com ele, compete ao Presidente da República 'sancionar, promulgar e fazer publicar as leis e regulamentos para sua fiel execução'. Evidencia-se, dessarte, que mesmo os atos mais conspícuos do Chefe do Poder Executivo, isto é, os decretos, inclusive quando expedem regulamentos, só podem ser produzidos para ensejar execução fiel da lei. Ou seja: pressupõem sempre uma dada lei da qual sejam fiéis executores ${ }^{73}$. (grifo do autor)

A legalidade tributária esta prevista no art.150, I, da CF/88 de modo que não se pode “(...)exigir ou aumentar tributo sem lei que o estabeleça”, assim nenhum tributo pode ser criado, aumentado, reduzido ou extinto senão por lei formal, e somente essa lei pode diminuir ou isentar tributos, parcelar ou conceder perdão de débitos tributários, criar obrigações acessórias.

As disposições constitucionais conferem às relações tributárias uma submissão rígida da legalidade, limitação ao poder de tributar, espécie de reserva legal em matéria tributária, em que a lei deve descrever todos os elementos essenciais do tributo, descrevendo conduta descrita, determinando os sujeitos da relação tributária, a base de cálculo e alíquota (tipicidade tributária).

Segundo a síntese de José Arruda Maria Trindade:

A superlegalidade tributária é a necessidade de a lei formal estar vinculada aos comandos deônticos constitucionais. É o reconhecimento da cogência e da superioridade da Constituição sobre as normas infraconstitucionais. No caso brasileiro, em que a $\mathrm{CF} / 88$ reserva um sistema constitucional tributário específico, com muitos dispositivos, a superlegalidade ganha mais relevância, como a necessidade de adequação da competência tributária definida constitucionalmente e sua decorrente prescrição legal (lei tributária em sentido estrito), na descrição dos aspectos materiais e quantitativos do tributo, por exemplo. A reserva da lei tributária exige lei em sentido

\footnotetext{
${ }^{73}$ BANDEIRA DE MELLO, Celso Antônio. Curso de direito administrativo. 6 a ed. São Paulo: Malheiros, 1995. p. 50 e seguintes.
} 
formal, quando se trata de aumentar ou exigir tributo. No art. 97 do CTN, a necessidade se estende a todos os aspectos da hipótese de incidência. Já o primado da lei prescreve a obrigatoriedade de a legislação infralegal atender o que fora prescrito na lei em sentido formal, ou seja, que a regulamentação não extrapole os limites da lei ${ }^{74}$. (grifos do autor)

Interessante mencionar que em sua obra Gerd Willi Rothmann, em um entendimento de como a legalidade se configura no sistema positivo constitucional que rege a atividade tributária ,aponta com especial juízo analítico, que o princípio da legalidade se manifesta em quatro feições distintas:

1) em primeiro lugar, a feição genérica (legalidade genérica (art.5 a , II, CF/88);

2) em segundo lugar, a feição administrativa ou da legalidade administrativa (art.37, caput, $\mathrm{CF} / 88$ );

3) em terceiro lugar, a "feição" tributária, ou seja, o princípio da legalidade tributária (art.150, II, CF/88);

4) em quarto lugar, a conformidade com o fato gerador (tipicidade tributária) ${ }^{\mathbf{7 5}}$.

A conformidade com o fato gerador que significa, em outras palavras, que todos os elementos do fato gerador devem ser descritos em lei, sem isso não há como cobrar tributos, tal entendimento distingue uma função diferenciada expressa pelo princípio da conformidade do fato gerador à lei tributária, ou seja não basta que haja a lei tributária, inserida regularmente no sistema jurídico, é requisito de validade que o texto legal permita a perfeita adequação entre a hipótese descrita e o fato ocorrido, para então se operar a incidência, subsunção e consequente nascimento da obrigação tributária.

Cumpre mencionar que, no Brasil, a medida provisória, ato legislativo expedido pelo Poder Executivo cria tributos, a despeito de todo o exposto, e da reprovação da doutrina pátria, posto que insere o Poder Executivo no campo de atuação tributária, sujeitando assim a criação de tributos não decorrente da vontade popular (representação) mas das flutuações das decisões e ideologias políticas do Poder Executivo, contrariando a Constituição Federal vigente, visto que com esse agir assume o papel originariamente delimitado ao Poder Legislativo, embora esse não seja o objetivo do presente trabalho, temos que é tema que ,por

\footnotetext{
${ }^{74}$ TRINDADE, José Maria Arruda. Legalidade tributária, segurança jurídica, pós-positivismo e a difícil relação entre política e direito. THESIS, São Paulo, ano III, v. 5, p. 58-96, $1^{\circ}$ sem. 2006.

${ }^{75}$ ROTHMANN, Gerd Willi. O princípio da legalidade tributária. In__. Direito Tributário. São Paulo: Editora, 1973. p.154 e ss. ( $5^{\mathrm{a}}$ Coletânea)
} 
sua relevância não pode prescindir de menção, e é oportuna é a reflexão trazida por Sainz de Bujanda, a respeito da crescente tendência da elaboração "legislativa" pelo Poder Executivo:

(...) Talvez seja mais árduo lograr as metas desejadas do caminho rigoroso que traz o Direito Legal, que pelo fácil caminho das decisões ministeriais. Mas em contrapartida, se dará daquele modo acima a uma obra sólida, firme, capaz de dar estabilidade à Fazenda pública e de infundir confiança e seguridade na vida econômica do país. Não duvidemos aquela fundamental advertência de Ripert: "Por trás do tumulto das revoluções, somente perdura a obra de jurista. Obra, lenta, difícil, solene, mas justa e segura"76.

O cotejo do princípio da eficiência e o princípio da legalidade deve considerar o viés de que não existem dois princípios da eficiência, mas devemos considerar a natureza das atividades desenvolvidas no desempenho da atividade financeira do Estado, e seu respectivo regime jurídico assim temos que em cotejo a atividade de criar recursos e arrecada-los o princípio da eficiência será contraposto ao juízo da eficácia, efetividade e eficiência sob um viés, dada a diferença de dado matéria (lei) e na atividade do gasto públicos outro, mas sempre de forma convergente a realizar os desígnios constitucionais.

A atividade de arrecadar tributo esta marcada pela relação Estado versus cidadãocontribuinte (interesse público versus interesses privados), o interesse público primário nessa relação, assim como em todas as relações de natureza pública é o atingimento do bem comum, sendo certo que o secundário é o interesse econômico.

Que em uma síntese dentro do marco teórico dos fundamentos de igualdade, liberdade e justiça, somente o Estado pode instituir tributos (consentimento pelo pacto social), apropriando-se do patrimônio pessoal dos cidadãos (em detrimento ao direito de propriedade) desde que essa atividade atenda aos interesses comuns, desde que não viole garantias e direitos individuais de proteção do cidadão contribuinte, a quem é permitido fazer tudo que a lei não proíbe.

O princípio da eficiência impõe ao Estado a necessidade do desenvolvimento de um planejamento eficiente e ação eficiente, para eficientemente tributar, sob esse aspecto temos que a legalidade é: (a) o fundamento da atividade de planejar e instituir tributos e, esta sujeita (b) a limitação que decorre (c.3) do estabelecimento de direitos e deveres materiais e formais aos integrantes dessa relação que nesse caso entendemos ser os direitos e garantias individuais do

\footnotetext{
${ }^{76}$ BUJANDA, Sainz F. La elaboracion corporativa de las disciplinas financieras. Revista de Derecho Financiero y Hacienda Pública, $n^{\circ}$ 70, p. 625-626. Madrid: Instituto de Estudios Fiscales, 1975 In BEREIJO, Alvaro Rodrigues. Introduccion Al Estudio Del Derecho Financiero. Madrid: Instituto de Estudios Fiscales, 1976.p.37.
} 
cidadão contribuinte; (d) finalidade de arrecadar conforme o interesse público, nos limites constitucionais.

Sendo certo que o cotejo do princípio da legalidade no exercício da atividade tributária ao princípio da eficiência ocorre no âmbito da eficácia, isso porque é nesse âmbito que o Estado realizará o (i) planejamento fiscal e estabelecerá metas a serem alcançadas; o (ii) agir concretamente para o alcance dessas metas, que pressupõe : (a) elaboração de política fiscal que pautara a atividade legislativa para a instituição dos tributos e obrigações acessórias tributárias, que no sentido estrito não estará adstrito a legalidade por ser metajuridico; (b) criação de meios eficientes de execução desses comandos legais para instituir e efetivar a arrecadação da receita tributária , nesse ponto é imperioso o cotejamento com o princípio da legalidade, visto que a criação de tributos esta subsumida à legalidade genérica e à legalidade estrita. $\mathrm{O}$ primeiro crivo da eficiência é elaborar o texto normativo em conformidade com a legalidade formal de acordo com o conteúdo da Lei Complementar 95 de 26 de fevereiro de 1998, em seguida deve-se passar a análise se o texto legal não afronta disposição expressa constitucional ou lei infraconstitucional e em especial se não fere as disposições constitucionais que limitem o poder de tributar, e as demais garantias asseguradas ao contribuinte ${ }^{77}$; d) disponibilização pelo Estado de meios eficientes de discussão e revisão desse "modo de agir" complexo na atividade financeira de perceber receita (legislar e executar as leis), constituindo a garantia do Estado de Democrático de Direito de acesso à eficiente revisão administrativa e judicial dos atos exarados pelos poderes Legislativo, Executivo e Judiciário. Cumpre mencionar que se trata de garantia constitucional, no entanto, a revisão administrativa pode se dar pela via do controle dos próprios atos, etapa anterior a litigância (administrativa ou judicial). Do ponto de vista do princípio da eficiência impende ressaltar que a revisão seja ela administrativa ou judicial decorre da ineficiência em qualquer fase das ações Estatais, sendo certo que em relação a revisão administrativa ou judicial resta afastada e ineficiência Estatal em qualquer das fases nos casos de

\footnotetext{
${ }^{77}$ Interessante nesse ponto trazer à colação Julgado do Supremo Tribunal Federal, que sintetiza as limitações impostas ao legislador tributário: “O Estado não pode legislar abusivamente, eis que todas as normas emanadas do Poder Público - tratando-se, ou não, de matéria tributária - devem ajustar-se à cláusula que consagra, em sua dimensão material, o princípio do substantive due process of law (CF, art. 5º LIV). O postulado da proporcionalidade qualifica-se como parâmetro de aferição da própria constitucionalidade material dos atos estatais. Hipótese em que a legislação tributária reveste-se do necessário coeficiente de razoabilidade." (RE 200.844-AgR, Rel. Min. Celso de Mello, julgamento em 25-6-2002, Segunda Turma, DJ de 16-8-2002.) No mesmo sentido: RE 480.110-AgR e RE 572.664-AgR, Rel. Min. Ricardo Lewandowski, julgamento em 8-92009, Primeira Turma, DJE de 25-9-2009 e também as taxas estão sujeitas aos princípios constitucionais que limitam a tributação (CF, art. 150, 151 e 152) e a outros princípios instituídos em favor do contribuinte pela norma infraconstitucional, já que os princípios constitucionais expressos são enunciados 'sem prejuízo de outras garantias asseguradas ao contribuinte' (CF, art. 150).” (ADI 447, Rel. Min. Octavio Gallotti, voto do Min. Carlos Velloso, julgamento em 5-6-1991, Plenário, DJ de 5-3-1993.)
} 
evidente má-fe do administrado no manejo da via revisional para a discussão de seus direitos materiais ou formais.

A aplicação do princípio da legalidade administrativa à atividade da gestão e do gasto público esta adstrita à dimensão da eficácia, efetividade e eficiência. O cotejo entre esses princípios foi, muito bem desenvolvido por Alexandre Santos de Aragão ${ }^{78}$, que traz a colação a síntese desse cotejo proposta na frase de Enrique Groismam:

\begin{abstract}
A mera juricidade da atuação estatal como elemento de legitimação se tornou insatisfatória a partir do momento em que começou também a ser exigida a obtenção de resultados. Não se considera mais suficiente que os governantes não violem a lei: exige-se deles a redução do desemprego, o crescimento econômico, o combate a pobreza, solução para os problemas de habitação e saúde. A discussão sempre se coloca em relação a quais são as políticas mais adequadas para atingir esses fins, mas não há dúvidas de que a lei deixou de ser apenas um meio para impedir a arbitrariedade para se converter em ponto de partida para uma série de atividades na quais há uma maior margem de delegação e de discricionariedade e um crescente espaço para técnica ${ }^{79}$.
\end{abstract}

A legalidade deve ser contraposta com o princípio da eficiência, na atividade financeira em suas três dimensões: eficácia, efetividade, eficiência, isso porque a administração adquire a obrigação do resultado eficiente, que passa a ser um critério validador conforme afirma Charles-Albert Morand ${ }^{80}$ : passam a ter o seu critério de validade aferido não "apenas em virtude da higidez do seu procedimento criador, como da sua aptidão para atender aos objetivos da política pública, além da sua capacidade de resolver os males que esta pretende combater".

O princípio da eficiência apenas se satisfaz da ponderação eficiente (racionalidade de valores como igualdade, justiça igualdade liberdade, proteção aos direitos e garantias fundamentais, racionalidade jurídica, ética) com a conjunção de suas três dimensões: eficácia, efetividade, eficiência, isso porque a realização da atividade administrativa financeira deve ser considerada em sua totalidade, sob o aspecto geral da legalidade, considerando a atividade de tributar, gerir e efetivar o gasto pública, pois todas se encontram submetida ao dever de resultado.

\footnotetext{
${ }^{78}$ ARAGÃO, Alexandre Santos de . O princípio da eficiência. Boletim de Direito Administrativo. São Paulo, NDJ, nº3, p. 320, mar.2005.

${ }^{79}$ GROISMAN, Enrique. Crisis e actualidad del derecho administrativo econômico. Revista de Derecho industrial, vol.42. p. 89. In ARAGÃO, Alexandre Santos de. O princípio da eficiência. Boletim de Direito Administrativo, São Paulo, NDJ, nº 03, p. 320, mar. 2005. p.320.

${ }^{80}$ MORAND, Charles-Albert. Le droit Neo-Moderne des Politiques Publiques. Paris: LGDJ, 1999. p.95.
} 
Sob esse aspecto, temos que a legalidade no exercício geral da atividade administrativa é (a) o fundamento (a.1) para fruição dos direitos fundamentais (primeira e segunda geração), e (a.2) fundamento para a instituição dos tributos; esta sujeita a (b) a limitação que decorre da (b.1) escassez natural dos bens públicos econômicos, (b.2) e da necessidade do atendimento do interesse coletivo em detrimento ao interesse individual , (c.3) da estabelecimento de direitos e deveres materiais e formais aos integrantes dessa relação que são o Estado e o cidadão que figura nessa relação ora na condição expressa pelo binômio cidadão contribuinte (interesses privados versus interesse público) - cidadão consumidor dos recursos públicos (interesses públicos versus interesses privados ) e por fim (d) a finalidade que é o exercício eficiente da atividade financeira atender de forma eficiente as necessidades públicas.

Isso porque o Estado tem o dever de, no âmbito da eficácia atender as necessidades públicas: (i) planejar e estabelecer metas a serem alcançadas; o (ii) agir concretamente para o alcance dessas metas e (iii) aferir racionalmente a relação entre as metas alcançadas e a metas pretendidas, isso por avaliação de desempenho ou performance, bem como constar as transformações ocorridas na realidade após a ação com o objetivo de alcançar as metas pretendidas, sendo certo que as transformações ocorridas na realidade podem ser consideradas positivas (pretendidas) ou negativas (não pretendidas). Em relação às transformações que operam na realidade (reações e resultados que produz) a efetividade está sujeita à ecologia da ação, tudo isso, ao menor custo financeiro, que o que denominamos eficácia.

O agir concretamente para o alcance dessas metas, que pressupõe o dever legal de : (a) elaborar políticas públicas para atender as necessidades publicas e política fiscal que pautara a atividade legislativa para a instituição dos tributos e obrigações acessórias tributárias, que no sentido estrito não estará adstrito a legalidade por ser metajuridico; (b) criação de meios eficientes de execução desses comandos legais para instituir e efetivar a arrecadação da receita tributária , gestão do patrimônio público e a despesa pública. O primeiro crivo da eficiência é elaborar o texto normativo em conformidade com a legalidade formal de acordo com o conteúdo da Lei Complementar 95 de 26 de fevereiro de 1998, em seguida deve-se passar a análise se o texto legal não afronta disposição expressa constitucional ou lei infraconstitucional e em especial se não fere as disposições constitucionais que ofertam garantias e direitos individuais, limitem o poder de tributar e se endividar, bem e as demais garantias asseguradas cidadão; d) disponibilização pelo Estado de meios eficientes de discussão e revisão desse "modo de agir" complexo na atividade 
financeira de perceber receita (legislar e executar as leis), constituindo a garantia do Estado de Democrático de Direito de acesso à eficiente revisão administrativa e judicial dos atos exarados pelos poderes Legislativo, Executivo e Judiciário. Cumpre mencionar que se trata de garantia constitucional, no entanto, a revisão administrativa pode se dar pela via do controle dos próprios atos, etapa anterior à litigância (administrativa ou judicial). Do ponto de vista do princípio da eficiência, impende ressaltar que a revisão seja ela administrativa ou judicial decorre da ineficiência em qualquer fase das ações Estatais, sendo certo que em relação à revisão administrativa ou judicial resta afastada e ineficiência Estatal em qualquer das fases nos casos de evidente má-fe do administrado no manejo da via revisional para a discussão de seus direitos materiais ou formais.

\subsection{O princípio da eficiência e o princípio da proporcionalidade}

A proporcionalidade pode ser entendida como um princípio hermenêutico conformador dos princípios constitucionais conflitantes, buscando solução de antinomias em que se verifique a adequação entre os meios e os fins constitucionais, diversamente entende Ávila que afirma ser o princípio da proporcionalidade um postulado ${ }^{81}$, mas há convergência na doutrina em entender que se trata de um princípio que serve e informa a Administração Pública, aplicável aos enunciados que implicam uma relação de causalidade entre um meio e um fim colimado, cuja aplicação necessariamente decorre da existência de princípios em conflitos.

A proporcionalidade é dotada de grande relevo prático, isso porque que entendemos que o Estado no exercício da atividade financeira deve sempre adotar medidas de planejamento e ações ${ }^{82}$,que atendam ao interesse público coletivo de forma eficiente ,de modo a menos restringir os direitos e garantias fundamentais da coletividade, a tal ponto que as vantagens jurídicas coletivas da realização da finalidade pretendida, superarem as desvantagens coletivas decorrentes da adoção da medida.

\footnotetext{
${ }^{81}$ Postulado normativo e não princípio na visão de Ávila: "considerando a definição de postulados como normas estruturantes da aplicação de princípios e regras" (ÁVILA, Humberto.Teoria dos Princípios da definição à aplicação dos princípios jurídicos. $4^{\mathrm{a}}$ ed. São Paulo: Malheiros, 2004. p.90).

${ }^{82}$ Ávila entende que a Administração Tributária está obrigada a escolher, entre as medidas adequadas para o atingimento de um dado fim, aquela que menos restringe os direitos dos contribuintes, ou seja, as vantagens jurídicas devem superar as desvantagens provocadas pela adoção da medida (AVILA, Humberto Bergmann. Sistema Constitucional Tributário. $3^{\text {a }}$. ed. São Paulo: Saraiva, 2008. p. 414. v.1)
} 
A teoria dos princípios desenvolvida por Dworkin e Alexy, foram desenvolvidas no ambiente dogmático brasileiro e bem explorada por Humberto Ávila que ao adotar o critério tríplice informado por Alexy, indica que para a completa avaliação da proporcionalidade são três os exames a serem providenciados: adequação, necessidade e proporcionalidade em sentido estrito $^{83}$.

A necessidade consiste em verificar dentre as medidas disponíveis e igualmente eficazes para atingir um fim, qual é a menos gravosa em relação aos direitos atingidos ${ }^{84}$.Nesse sentido, Humberto Ávila afirma que:

O exame da necessidade envolve a verificação da existência de meios que sejam alternativos àquele inicialmente escolhido pelo Poder Legislativo ou Poder Executivo e que possam promover igualmente o fim sem restringir, na mesma intensidade, os direitos fundamentais afetados ${ }^{85}$.

Duas são, assim, as verificações relativas à necessidade: primeiramente, verificar se os "meios alternativos promovem igualmente o fim; em segundo lugar, o exame do meio menos restritivo, ou seja, verificar se os meios alternativos restringem em menor medida os direitos fundamentais colateralmente afetados" ${ }^{\prime 86}$.

O segundo aspecto para a verificação da proporcionalidade é o da adequação, isto é, analisar se o meio imposto é apropriado para atingir o fim ao qual se propõe. A "adequação exige uma relação empírica entre o meio e o fim: o meio deve levar à realização do fim" 87

Por fim, deve ser proporcional em sentido estrito, isto é, proíbe-se o excesso, devendo as prestações limitar-se ao suficiente para atingir os fins colimados, "exige a comparação entre a importância da realização do fim e a intensidade da restrição aos direitos fundamentais $^{88}$ " Tal critério revela, portanto, uma necessidade de ponderação entre o meio adotado e a limitação sofrida pelo indivíduo em parcela juridicamente protegida.

Na definição de Virgílio Afonso da Silva afirma que a proporcionalidade em sentido estrito “(...) consiste em um sopesamento entre a intensidade da restrição ao direito

\footnotetext{
${ }^{83}$ AVILA, Humberto Bergmann. Sistema Constitucional Tributário. 3a . ed. São Paulo: Saraiva, 2008. p. 414. v.1

${ }^{85}$ ÁVILA, Humberto.Teoria dos Princípios da definição à aplicação dos princípios jurídicos. $4^{\mathrm{a}}$ ed. São Paulo: Malheiros, 2004. Princípiop.122.

${ }^{86}$ Idem, ibidem p. 122.

${ }^{87}$ PrincípioIdem, ibidem. p. 116

${ }^{88}$ ÁVILA, Humberto.Teoria dos Princípios da definição à aplicação dos princípios jurídicos. $4^{\mathrm{a}}$ ed. São Paulo: Malheiros, 2004. Princípiop.124.
} 
fundamental atingido e a importância da realização do direito fundamental que com ele colide e que fundamenta a adoção de medida restritiva"89.

Podemos inferir que para que uma medida seja considerada desproporcional em sentido estrito, basta que os motivos que fundamentam a adoção da medida não tenham peso suficiente para justificar a restrição ao direito fundamental atingido, avaliando dessa forma, por exemplo, pode ocorrer uma restrição considerada pequena, distante de implicar a não realização de algum direito. Porém, se a importância da realização do direito fundamental, no qual a limitação se baseia, não for suficiente para justificá-la, será ela desproporcional.

Cumpre mencionar que do ponto de vista da significação jurídica proporcionalidade e razoabilidade não são sinônimos, como aponta José Afonso da Silva, visto tratar-se de topoi a construir o argumento que descreve a subsunção à adequação, à necessidade e proporcionalidade em sentido estrito, de modo que sintetiza "A regra da proporcionalidade, contudo, diferencia-se da razoabilidade não só pela sua origem, mas também pela sua estrutura"90. Em oposição, a abertura conceitual que Ávila faz ao entender possível compreender a razoabilidade como equidade, como congruência, e por fim como equivalência.

A posição divergente dos dois autores, em verdade enriquecem a precisão a que se deve dar a construção dos conceitos para sua utilização, nesse passo, de forma a complementar e conciliar os entendimento, inferimos que o postulado da razoabilidade e da proporcionalidade funcionam como um limite à discricionariedade administrativa, sendo certo que a racionalidade trabalha no âmbito da construção do argumento do juízo tríplice de análise , conferindo a eles uma motivação racional que pressupõe a construção de argumento válido em oposição a argumentos falaciosos ou retóricos.

Tal visão não altera a aplicação da proporcionalidade que exige a relação de causalidade entre meio e fim, de tal sorte que, adotando-se o meio contribui-se para a promoção do fim, com o auxilio da razoabilidade que impõe, para a construção de argumentos validos os deveres de equidade, que implicará na congruência, coerência, que não impedirá a ocorrência da equivalência entre a imposição estabelecida e as consequências dela advindas.

\footnotetext{
${ }^{89}$ SILVA, Virgilio Afonso da. O proporcional e o razoável. Revista dos Tribunais, São Paulo, 798, p. 40, 2002.

${ }^{90}$ Idem, ibidem. p.29
} 
Explicitando as explanações de Ávila postulado da razoabilidade atua, portanto, sendo condutor dos seguintes valores: equidade, congruência, equivalência e coerência.

A razoabilidade-equidade é utilizada como critério que exige a relação das normas gerais com as individualidades do caso concreto, seja mostrando sob qual perspectiva a norma deve ser aplicada, seja indicando em quais hipóteses o caso individual, em virtude de suas especificidades, deixa de se enquadrar na norma geral.

A razoabilidade-congruência exige uma vinculação das normas jurídicas com o mundo ao qual elas fazem referência, reclamando uma relação congruente entre a medida adotada e o fim que ela pretende atingir.

A razoabilidade-equivalência é utilizada como critério que exige a relação de equivalência entre duas grandezas, como ocorre no caso da exigência de correspondência entre a pena e a culpa, ou entre a taxa e o serviço público prestado.

Por fim, a razoabilidade-coerência é diretriz que exige a consistência entre os elementos constantes de uma regra jurídica, proibindo a validade de normas que instituem deveres contraditórios ou sem qualquer sentido prático.

A razoabilidade opera, portanto, no balizamento entre o critério e a medida adotados no ato interpretado, na busca do dever de equidade, congruência ou de equivalência.

A razoabilidade tem uma função negativa - não ultrapassar os limites do juridicamente (racional) aceitável -, a proporcionalidade teria uma função positiva, qual seja, a de demarcar os limites, indicando como se mantém dentro deles. Portanto, os postulados da razoabilidade e da proporcionalidade expressam construções jurídicas diversas.

O princípio da proporcionalidade exerce dupla função ao ser aplicado ao princípio da eficiência isso porque tem o objetivo de aferir a harmônia interna entre os três juízos de valor que compõe o princípio da eficiência bem como possibilitar a harmonização externa desse princípio com os demais contidos no sistema jurídico brasileiro.

\subsection{A atividade de interpretação e a promoção do princípio da eficiência}

A interpretação do enunciado legal é pressuposto para a aplicação do direito. Dele, pelo processo cognitivo, constrói-se a norma jurídica que será aplicável à situação fática. 
A concepção do direito como ciência é recente e o ponto de apoio pode ser assentado em Savigny (1779 -1861).

A avaliação das teorias formuladas para explicar os fenômenos jurídicos guarda muito de carga de temporalidade. As leis fazem apenas recortes da realidade passada que, muitas vezes, não se comunica com a dimensão real dos problemas, que por princípio, seria seu objetivo solucionar.

O direito (como conjunto de leis que regem o comportamento) tem caráter hipotético-dedutivo, e até meados do século XIX não havia uma organização ou a montagem de contornos sistemáticos que caracterizassem o conhecimento jurídico como uma especialidade, uma seara, que pudesse ter um método próprio.

A assertiva ganha contornos práticos quando relembramos o processo formular no direito romano, pois esse método de pacificação de conflito a verdade não residia no que era o discurso (enunciado prescritivo), ou no que ele fazia, mas residia no que ele dizia e assim ,segundo Michel de Foucault "chegou o dia em que a verdade se deslocou do ato ritualizado, eficaz e justo da enunciação, para o próprio enunciado: para seu sentido, sua forma, seu objeto, sua relação e sua referência" ${ }^{91}$. Nesse ponto importante a observação pontuada por Michel de Foucault :

\begin{abstract}
Ainda nos poetas gregos do sec.VI, o discurso verdadeiro- no sentido forte e valorizado do termo - o discurso verdadeiro pelo qual se tinha respeito e terror, aquele ao qual era preciso submeter-se, porque ele reinava, era o discurso pronunciado por quem de direito e conforme o ritual requerido; era o discurso que pronunciava a justiça e atribuía a cada qual sua parte; era o discurso que,profetizando o futuro, não somente anunciava o que ia se passar,mas contribuía para a sua realização,suscitava a adesão dos homens e se tramava assim com o destino.Ora eis que um século mais tarde, a verdade já não residia nas no que era o discurso, ou no que ele fazia, mas residia no que ele dizia: chegou um dia em que a verdade se deslocou do ato ritualizado,eficaz e justo, de enunciação, para o próprio enunciado: para seu sentido,sua forma,seu objeto,sua relação a sua referência.Entre Hesíodo e Platão uma certa divisão se estabeleceu, separando o discurso verdadeiro e o discurso falso;separação nova visto que,doravante,o discurso verdadeiro não é mais o discurso precioso e desejável,visto que não é mais o discurso ligado ao exercício do poder. O sofista é enxotado.Essa divisão histórica deu sem dúvida sua forma geral à nossa vontade de saber.Mas não cessou, contudo de deslocar: as grandes mutações científicas podem talvez ser lidas, às vezes,como conseqüências de uma descoberta, mas podem também ser lidas como a aparição de novas formas na vontade da verdade.Há sem dúvida, uma vontade de verdade no século XIX, que não coincide nem pelas formas que põe em jogo,nem pelos domínios de objeto aos quais se apóia, com a vontade de saber que caracteriza a cultura clássica. ${ }^{92}$
\end{abstract}

\footnotetext{
${ }_{91}^{91}$ FOUCAULT, M. A Ordem do Discurso. Aula ministrada em 02/12/1970. São Paulo: Loyola, 1996. p.15.

${ }^{92}$ Idem, ibidem. p. 16.
} 
A conjunção de fatores da busca pela verdade criou a necessidade do tratamento científico do direito, e de certa maneira coincide com o desenvolvimento geral de uma vocação para o conhecimento metodizado, parametrizado para alcançar resultados de conhecimento cientificamente avalizados.

Cumpre mencionar a influência da dimensão temporal e histórica no direito, nas leis, nos instrumentos e nos procedimentos adotados para prevenir e solucionar conflitos e também dos modos como eles são explicados, e por fim compreendidos, esse plexo de variáveis estão submetidos à influência do tempo e do espaço em que se desenvolvem.

Quanto ao aspecto subjetivo temos o fator importante a ser considerado, pois ser humano,como interprete, carrega toda a sorte de sentimentos, pulsões (aqui cabem os interesses) - fatores internos- e também, o conhecimento geral, do sistema legal e também doutrinário - fator externo internalizado.

Toda essa plêiade de informações acompanha o ser humano interprete, todos esses fatores influenciam na avaliação de métodos de interpretação bem como na aptidão do ser humano para dar respostas aos problemas absorvidos pelo direito.

A estrutura funcional buscada para desvendar o "mistério do enunciado legal" ou a qualificação do fato, busca superar duas questões: primeiro o alcance do sentido do texto e a segundo a compreensão qualificada do fato.

O sentido do texto é alcançado com auxílio da ciência jurídica e da hermenêutica, mas cumpre ressaltar, que ainda assim esbarramos na dificuldade apontada por Canaris:

Que uma doutrina "seja correta em teoria, mas não sirva para a prática", não é
compatível com a orientação aplicativa das teorias jurídicas, e, portanto, bem posto
o tema, é uma situação que, de nenhum modo, pode dar-se; ao contrário, frente a
uma contradição deste caráter, se deverá abandonar ou corrigir a teoria ou modificar
a prática ${ }^{93}$. (grifo do autor)

Importante ressaltar que entendemos, assim como Alfredo Augusto Becker que a interpretação, por ser método, permite que façamos a separação dos momentos de sua ocorrência assim temos:

\footnotetext{
93 "Que una doctrina 'sea correcta en teoría, pero no sirva para la práctica', no es compatible con la orientación aplicativa de las teorías jurídicas, y, por tanto, bien mirado, es uma situación que, de ningún modo, puede darse; antes bien, frente a una contradicción deeste carácter, se deverá abandonar o corregir la teoría o modificar la práctica." (CANARIS, Claus-Wilhelm. Fúnción, estructura y falsación de las teorías jurídica. Daniela Brückner, José Luiz de Castro (Trads). Madrid: Civitas, 1995. p. 120).
} 
(i) Primeiro momento: dissecar a estrutura lógica da regra jurídica que será objeto da interpretação. Isola-se a regra como "fórmula literal legislativa" (BECKER, PP. 121). Apreende-se a regra jurídica a partir da interpretação histórica (plano vertical) e a interpretação sistemática (plano horizontal). Neste momento que verifica-se a validade da norma (se há antinomias, inconstitucionalidades etc.)

(ii) Segundo momento: Analisar os fatos jurídicos e não jurídicos que envolvem o problema a ser solucionado. Avalia-se a hipótese de incidência foi efetivamente realizada.

(iii) Terceiro momento: Com a realização da hipótese de incidência e a incidência "infalível" da norma, avalia-se os efeitos decorrentes daquela realização, sendo predeterminados pela regra de conduta (efeitos jurídicos se irradiaram sobre o fato após a concretização da hipótese).

(iv) Quarto momento: avaliação se os efeitos da norma foram efetivamente observados/respeitados. ${ }^{94}$

Assim entendemos que a hermêutica fixa as regras metodológicas/cientificas para interpretação dos enunciados legais e a ciência jurídica (doutrina) esclarece os conceitos contidos no texto legal e a relação de coordenação entre os diversos enunciados legais (sistema normativo).

A questão crucial é que o conceito tem, muitas vezes, uma natureza meramente teorética (abstrata) que só se aperfeiçoa com a captação do fato, com a adequação de todos os seus elementos aos aspectos vivos de uma determinada realidade. Duguit exemplifica bem esse traço caraterístico da abstração, utilizando como um exemplo idéia de direito subjetivo:

O conceito é idéia de uma coisa que não pode ser objeto de percepção direta; a hipótese é suposição de um fato comprovável pelos sentidos. Assim, ainda que se considere que o conceito de direito subjetivo responda a uma realidade, ela não será nunca vista. A frase de um colega: Monsieur n'a pás dejeuné avec un droit $(\mathrm{O}$ senhor não almoçou com um direito) demonstra que esse direito não é uma realidade, mas uma simples concepção do espírito ${ }^{95}$.

O direito como construção abstrata de conceitos e hipóteses por ser dinâmico e para ser dinâmico alberga mais valores do que a referência pelas palavras contidas no enunciado prescritivo.

Diante dessa complexidade de fatores conceituais, a opção por determinado método hermenêutico, bem como por determinado marco teorético, possibilita a produção de entendimentos, muitas vezes distintos, mas ambos válidos e legítimos sob o aspecto

\footnotetext{
${ }^{94}$ BECKER, Alfredo Augusto. Teoria Geral do Direito Tributário. São Paulo: Saraiva, 1953. p. 102-103.

${ }^{95}$ DUGUIT, Leon. El pragmatismo jurídico. Agustín de Lázaro Álvarez, Santiago Magariños Torres, Tomás Díaz García e Miguel López-Roberts y de Chávarri (Trads).Madrid: Francisco Beltrán, 1924. p.104
} 
científico. Nesse ponto reside a controvérsia, em que cada jurista busca demonstrar a invalidade, do método hermenêutico utilizado ou a imprestabilidade do marco teorético.

Isso ocorre principalmente porque o enunciado legal é texto inerte e disponível à sabedoria do jurista ou à paixão do déspota. Assim o ponto de risco (de diversas naturezas) reside tanto na criação do enunciado quanto na ação daqueles que atuam na construção de sentido do texto, assim já professava Rudolf von Jhering:

\begin{abstract}
Crença e superstição, barbarismo e cultura, vingança e amor, crueldade e humanidade - o que mais mencionarei? - tudo isso encontrou boa acolhida na lei. Sem opor resistência, ela parece render-se a todas as influências poderosas o bastante para torná-la útil a elas, sem ter um apoio fixo próprio. A contradição, a mudança externa, parece constituir o conteúdo essencial da lei [...] $\mathrm{O}$ direito não pode fazer sempre os mesmos regulamentos; ele precisa, do mesmo modo, de adaptá-los às condições do povo, a seu grau de civilização, às necessidades do tempo [...] Um direito universal para todas as nações está na mesma linha que um remédio universal para todas as pessoas doentes ${ }^{96}$.
\end{abstract}

O autor supramencionado, em sua obra, aponta uma perspectiva tríplice da ciência do direito: em que (i) a filosofia do direito oferece os fundamentos, (ii) a história do direito permite seu aperfeiçoamento e (iii) a dogmática que por meio da aplicação prática ordena uma representação cientifica de todas as experiências e fatos, os quais encerram em si um ponto final e mais alto na compreensão do direito.

Jhering trouxe para o conhecimento jurídico os fundamentos de interesse e da finalidade, a visão supramencionada visão de destaca a participação da experiência prática na realização da ciência do direito e na sua construção teórica, que nos permite inferir que a construção da norma não se faz apenas da aferição do enunciado legal.

Descrevendo a característica normativa da generalização abstrata na construção hipotética do texto jurídico e as consequências sob o ponto de aspecto formal e material ,e teleológico, assim se coloca François Ost:

A validade da norma não resulta com efeito mais do que parcialmente de critérios
jurídicos formais e explícitos; ao contrário, sua inteligibilidade (o sentido que lhe é
prestado) é amplamente reconstruída pelo órgão de aplicação com referência a
princípios e valores implícitos; de modo que a "textura aberta" caracteriza não só
cada norma considerada isoladamente, mas também o sistema jurídico encarado
globalmente. Sob pena, pois, seja de reduzir o objeto estudado a uma representação
truncada e enganadora, seja de endossar implicitamente suas proposições e dogmas,

\footnotetext{
${ }^{96}$ JHERING, Rudolf von. A finalidade no direito. In: MORRIS, Clarence (Org.). Os grandes filósofos do Direito. Trad. Reinaldo Guarany. São Paulo: Martins Fontes,., 2002. p. 417.
} 
a análise do fenômeno jurídico não pode limitar-se à "descrição" de um dado fronteiriço e à consistência que é tão incerta ${ }^{97}$. (grifos do autor)

Isto leva a que o método não possa desprezar a concreção como uma linha essencial nos planos do conhecimento jurídico como enfatiza Alf Ross: "Toda declaração abstrata sobre o direito é uma irrealidade, uma hipótese. Só o direito plenamente concreto é real. O direito abstrato é sempre uma mera hipótese acerca do direito concreto ${ }^{98}$ ".

O conhecimento do direito não é limitado por divisas claras e insuperáveis, pois não se restringe à norma, ao fato, à atuação do juiz ou apenas a sua expressão doutrinária, mas sim à complexa inter-relação de todos esses elementos.

A interpretação do direito, nesse aspecto, é que tem o condão de construir o sentido da norma que irá jurisdicizar determinado fato, em última análise, o que sem dúvida é um instrumento de poder, conforme podemos inferir das recentes discussões sobre o ativismo judicial que busca identificar o papel e os limites de atuação do juiz dentro do sistema legal.

Mas o que é interpretar?

Na visão de Ronald Dworkin, o direito não é apenas um empreendimento interpretativo, mas deve também ser explicado pelos métodos empregados pelos participantes; tanto teóricos como práticos estão engajados e único e mesmo tipo de raciocínio,ou seja, numa tentativa de impor a melhor interpretação à prática que encontram. Assim o conceito de direito e a justificativa de suas exigências particulares já não podem ser vistos como duas questões separadas. A teoria interpretativa de Dworkin parece sustentar uma postura antipositivista da norma.

Carlos Maximiliano entende que interpretar é explicar, esclarecer, dar o significado de vocábulo, atitude ou gesto; reproduzir por outras palavras num pensamento exteriorizado,mostrar o sentido verdadeiro de uma expressão;extrair de frase, sentença ou norma, tudo o que na mesma se contém.

\footnotetext{
97 OST, François. Ciencia del Derecho. Trad. Oscar Luis Sarlo e Enrique P. Haba In: PALOMINO MANCHEGO, José F (Org.). Discussión sobre el carácter anticientífico del derecho: de Kirchmann a la discussión epistemologica actual. Lima: Grijey, 1999, p. 245.

${ }^{98}$ ROSS, Alf. Teoria de las fuentes del derecho: una contribución a la teoría del derecho positivo sobre la base de investigaciones histórico-dogmáticas. José Luis Muñoz de Baena Simón, Aurelio de Prada Garcia, Pablo López Pietsch (Trads).Madrid: Centro de Estudios Políticos y Constitucionales, 1999. p.354.
} 
O mesmo autor frisa que interpretar uma expressão de direito não é simplesmente tornar claro o respectivo dizer,abstratamente falando, é, sobretudo, revelar o sentido apropriado do texto para a vida real e conducente com uma decisão reta.

Interessante mencionar a perspectiva dada por Andrei Marmor sob a qual uma teoria da interpretação forneça respostas a 03 questões: (i) sobre os possíveis objetos da interpretação; (ii) sobre o seu objeto, sua base normativa; (iii) e a questão epistemológica sobre a qual é a possibilidade de conhecimento nesse campo - por exemplo se existem interpretações corretas e incorretas e se a interpretação é objetiva em algum sentido.

Tércio Sampaio Ferraz ${ }^{99}$ nos fornece três perspectivas de análise cientifica, quais sejam : (i) teoria da norma (modelo analítico); (ii) teoria da interpretação (modelo hermenêutico); (iii) teoria da decisão (modelo empírico).

Em apertada síntese a teoria da norma é um modelo analítico, que procura destacar os vários componentes de seu objeto de estudo, dividindo-os em tantas partes quanto forem possíveis ou úteis à melhor compreensão da matéria. A referida teoria faz um recorte na realidade do direito, focando a norma jurídica e abstraindo o que não é normativo, como questões relacionadas à valoração (ex. justiça).

As técnicas possíveis de serem utilizadas, segundo o citado autor, na opção pelo modelo analítico são: (a) análise dedutiva; (b) análise indutiva; (c) analogia; (d) lógico formal.

A teoria da interpretação parte do postulado quase universal de que não há norma sem interpretação. Agrega a noção de sistema (conjunto de elementos interligados dedutivamente). A concepção de sistema destaca a importância dos princípios jurídicos a partir das quais as regras jurídicas serão deduzidas.

As técnicas possíveis de serem utilizadas, segundo o citado autor, na opção pelo modelo hermenêutico são: (a) técnica gramatical; (b) técnica lógica; (c) técnica sistemática; (d) técnica histórica.

A teoria da decisão (modelo empírico) procura expor que o direito e, mais particularmente, a ciência do direito é um tecnologia, não apenas uma técnica. Isso porque pretende demonstrar que o a ciência do direito assemelha-se a um manual de procedimentos e como tecnologia a ciência jurídica visa interferir nas decisões do aplicador do direito.

\footnotetext{
99 TEORIA da norma jurídica. Disponível em <http://www.terciosampaioferrazjr.com.br/?q=/publicacoes-
} cientificas/13>. Acesso em 11/10/2012. 
Nesse diapasão apresenta e analisa as possibilidades decisórias sob as seguintes teorias: (a) teoria da decisão propriamente dita; (b) teoria da comunicação; (c) teoria da subsunção; (d) teoria do suposto fático; (e) teoria das decisões apriorísticas; (f) teoria da legalidade; $(\mathrm{g})$ teoria do controle de comportamentos.

A essa metodologia adicionamos a contribuição de Niklas Luhmann ${ }^{100}$, em que o conceito de "sistema" cujos elementos estão distinguidos e, relativamente isolados, do ambiente, que representa todos os outros elementos que não compõem o sistema.

O sistema se estabelece a partir de uma ruptura com o ambiente, capaz de criar nele uma estrutura que é relativamente autônoma de todo o resto. Esse corte ou ruptura se chama "diferenciação" que se trata de uma certa forma de organização e de funcionamento.

Considerando como ambiente todo o conjunto de normas jurídicas um sistema representa corte desse conjunto à partir da possibilidade, dessa estrutura sobreviver autonomamente. Assim podemos exemplificar a existência do Direito Tributário, que sobrevive autonomamente dentro do ambiente ao qual pertence que é o ambiente do Direito Financeiro.

Nesse ponto, afirmamos que o método de interpretação não guarda especialidade ou distinção para cada ramo que supomos dividir-se o direito, por ser método.

Diferente do marco teorético do conteúdo das proposições legais, por ser atividade realizada pelas ciências jurídicas, em relação a cada ramo do direito, e assim então existe a possibilidade de especialidade.

Isso ocorre justamente porque conjunto de regras de direito compõe um sistema uno, o ordenamento jurídico vigente, o critério discrimine se dá apenas por se percorrer o caminho de identificar quais enunciados prescritivos são aplicáveis em cada ramo (divisão didática, corte epistemológico) do direito, isso corresponde à diferenciação, ou seja, a identificação de artigos de lei específicos aplicáveis bem como os princípios e regras jurídicas aplicáveis a esse ramo.

Interessante mencionar a "Crítica da Razão Pura"101 (Kritik der reinen Vernunft), publicada inicialmente em 1781, que traz a diferenciação do conhecimento empírico, que guarda relação com as percepções dos sentidos, a significar que são posteriores à experiência

\footnotetext{
${ }^{100}$ LUHMANN, Niklas. Conhecimento como construção. In: NEVES, C.B.; SAMIOS, E.M.B. Nova teoria dos sistemas. Porto Alegre: Ed. da Universidade/Goethe Institut, 1997.

101 KANT , Emmanuel. Crítica da Razão Pura. J. Rodrigues de Merege (Trad.). Disponível em <http://br.egroups.com/group/acropolis/>. Acesso em 15/07/2011
} 
e o conhecimento puro, é aquele que não depende dos sentidos, isto é, anterior à experiência, ou seja, a priori, e depende de uma afirmação universal que, para ser válida, não depende de nenhuma condição específica.

O conteúdo da obra permite afirmarmos que o conhecimento verdadeiro só é possível pela conjunção entre matéria, proveniente dos sentidos, e forma, que são as categorias do entendimento.

Assim compreendemos que a priori não se obtém um conhecimento, mas se pode saber quais são as categorias segundo as quais o conhecimento é formulado, segundo as leis da razão. E a priori como forma de categorizar a forma quer significar antes da experiência prática.

Ainda ao iniciar a obra esclarece sobre a diferença entre os "juízos sintéticos" e "juízos analíticos". Em que o primeiro é aquele que, através da junção de informações distintas chega a uma nova informação. O segundo se refere a dividir um mesmo objeto em seus constituintes, de modo que suas partes se tornem mais claras, mas que nada mais surja, a não ser aquilo que previamente já estava contido no próprio objeto.

Assim com apoio na obra mencionada entendemos que a interpretação do enunciado legal, sem a ocorrência do fato no mundo real, se utiliza de "juízos analíticos" a priori, circunda o conhecimento, reproduzindo-o, aclarando-o com palavras diferentes, chegando a conclusões que em nada diferiam daquilo que já estava contido no enunciado legal, sem produzir, assim, qualquer novo conhecimento a respeito das questões sobre as quais eram formuladas, estar-se-á apenas construindo o sentido dentro do sistema ao qual ele pertence.

Nessa esteira, ao buscar a formação do juízo a priori, descartamos a análise da interpretação da lei em conjunto com a qualificação do fato (prescinde de provas), que seria a aplicação da lei financeira.

Assim, retomando algumas premissas entendemos que a formação do juízo analítico a priori em matéria de ciência jurídica tem como dado material uma lei, que não carece de método hermenêutico específico para ser interpretada, o interprete fará a eleição do método que melhor lhe aprouver, mas essa lei deve esta subsumida a um sistema regido por regras e princípios que lhe, muitas vezes será a tal grau de ruptura que o ao objeto de estudo será a diferenciação. 
Concordamos com a assertiva presente na obra de Ricardo Lobo Torres ${ }^{102}$ que "um certo grau de ideologia é inevitável na interpretação do Direito”, mas se aplica a adoção de marcos teóricos (filosofia jurídica e correntes doutrinárias especificas de cada ramo do direito), mas a dúvida sobre os elementos indispensáveis que compõem a hipótese de normativa não comporta a adoção de marcos teórico ou o hipotético é perfeitamente descrito ou não o é.

As relações jurídicas desenvolveram-se em um ambiente normativo, o primado da segurança jurídica é predicado, posto que a segurança é uma necessidade do homem e da sociedade, e com ela torna-se possível conduzir, planejar responsavelmente sua vida, busca com grau mínimo de previsibilidade, saber no que confiar e no como se guiar e, amenizando suas ansiedades, suas inquietudes, que podem surgir da incerteza nas relações sociais.

No sentido objetivo, a segurança jurídica manifesta-se como requisito para regularidade lógica, estrutural e funcional do ordenamento jurídico, expressa nos enunciados e instituições.

No sentido subjetivo, a segurança jurídica, também chamada de princípio da proteção da confiança, expressa a segurança jurídica, não apenas como a certeza do direito, mas sim como a certeza da regulação de condutas, ou seja, como projeção da segurança objetiva nas situações pessoais. Isso se realiza por completo quando o indivíduo tem conhecimento do direito, valendo-se da máxima civil que ninguém pode alegar desconhecer a lei. Devendo-se a este prévio conhecimento do prescrito, permitido ou proibido, de forma a poder organizar suas condutas presentes e programar suas ações futuras, com objeto jurídico, sob a luz da previsibilidade.

Observamos, na obra de Canotilho, o princípio da segurança jurídica, em seu sentido amplo (objetivo e subjetivo), do seguinte modo:

O indivíduo tem o direito de poder confiar em que aos seus actos ou às decisões públicas incidentes sobre os seus direitos, posições ou relações jurídicas alicerçados em normas jurídicas vigentes e válidas por esse actos jurídicos deixado pelas autoridades com base nessas normas se ligam aos efeitos jurídicos previstos e prescritos no ordenamento jurídico ${ }^{103}$ (conforme original).

\footnotetext{
102 TORRES, Ricardo Lobo.Normas de Interpretação e Integração do Direito Tributário. Rio de Janeiro, Forense, 1994.

${ }^{103}$ CANOTILHO, Jose Joaquim Gomes. Direito Constitucional e Teoria da Constituição. Sao Paulo: Almedina, 2003.p.256
} 
Assim dada às proposições que devemos inferir na realização na construção do conteúdo jurídico do princípio da eficiência na atividade financeira do Estado é de suma importância a eleição do método de interpretação, bem como o marco teórico fixado.

Assim fixamos as premissas pelas quais passaremos a analisar a interpretação. Inicialmente adotamos a premissa que o dado material do interprete do direito é a lei, nesse caso a interpretação de leis aplicáveis a atividade financeira do Estado, a interpretação será realizada, com auxílio da hermenêutica, se dará com a fixação do método interpretativo teleológico, o marco teorético (orientação filosófica jurídica) adotado é a jurisprudência de valores e a biopolítica.

Tudo isso considerando o conjunto de leis como um sistema, que em seu sentido lógico e teleológico quer dizer, um conjunto de elementos interconexos, que se referem e se implicam mutuamente (sistema em sentido lógico) e como conjunto de elementos solidários na consecução de uma ou mais finalidades previamente fixadas (sistema em sentido teleológico), isso para a construção de juízos sintéticos a priori.

\subsection{O princípio da eficiência e a discricionariedade administrativa}

A discricionariedade, na visão de Amílcar de Araújo Falcão ${ }^{104}$, tributarista, e na visão de administrativistas, como Diógenes Gasparini ${ }^{105}$, indica ao aplicador do direito uma margem que possibilita a este escolher entre uma ou mais soluções legais possíveis para resolução da questão posta a análise do agente administrativo.

Para realizar esta opção, o aplicador utilizará requisitos pré-existentes no sistema legal, a própria norma e os princípios regentes do sistema jurídico in casu.

Qualquer das opções, desde seja devidamente fundada em opção prevista em lei, e respeitar determinados contornos e pré-requisitos do caso fático, respeitar os princípios do sistema legal, será válida. Na verdade, o aplicador decidirá por uma entre as soluções legais possíveis para o caso.

Cumpre mencionar uma diferenciação entre termos jurídicos indeterminados e discricionariedade, indica ao aplicador do direito uma margem que possibilita a este escolher entre uma ou mais soluções legais para a situação fática, qualquer das opções legais motivada,

\footnotetext{
${ }^{104}$ FALCÃO, Amílcar de Araújo. Fato gerador da obrigação tributária. Sao Paulo: Saraiva, 2001. p.59-63

${ }^{105}$ GASPARINI, Diógenes.Curso de Direito Administrativo. Sao Paulo: Saraiva, 1999.p.92
} 
que respeite os pré-requisitos do caso fático determinado, e os princípios do sistema legal, será válida.

O termo jurídico indeterminado não permite esse tipo de solução, ou seja, não existe uma gama de opções para se escolher a lei que melhor atende ao caso. Para buscar a solução o aplicador terá que transpor primeiro a barreira de transformar o enunciado prescritivo, e construir um significado para o termo, até então indeterminado. E, por último, construir a norma com base nos enunciados prescritivos construído, contextualizado no sistema jurídico, que será aplicado no caso.

No processo de construção da norma, o aplicador levará em conta requisitos normativos, princípios jurídicos, dados empíricos e fáticos, não para aplicar o direito, mas sim também para de certa forma, "criar", dar vida e significação ao termo para chegar ao direito a ser aplicado, e também pelo processo de interpretação do que o legislador pretendeu alcançar, com a inclusão naquele enunciado de um conceito aberto.

Tanto na possibilidade de discricionariedade como na presença de termo jurídicos indeterminados existe o momento subjetivo, no entanto, é clara a diferença do tempo e modo de ocorrência.

No primeiro caso, a norma está quase "pronta" no enunciado, a subjetividade apenas aparece pelo fato do aplicador escolher entre a solução legal, que em sua subjetividade, melhor atende a situação fática.

$\mathrm{Na}$ aplicação de enunciado que contém um conceito jurídico indeterminado, a subjetividade surge no momento de "construção" a norma a ser aplicada a partir do enunciado "não pronto".

Nesse ponto, é importante mencionar que a construção da referida norma a ser aplicada na verdade resulta em ato administrativo que deve obedecer todos os pressupostos e requisitos legais para sua edição, e também que sua edição pode ser submetida ao controle de legalidade tanto interno, quanto aquele realizado pelo judiciário.

A motivação do ato administrativo e de extrema importância nessa etapa, posto, que fornecera os elementos que o sujeito cognoscente analisou, a relação de pertinência entre eles e por fim justificara a o conteúdo decisório do administrativo. 
A necessidade de motivação do ato administrativo emana em apertada síntese da Constituição Federal e esta presente no art. $1^{\circ}$, inciso II que indica a cidadania como um dos fundamentos da República; no parágrafo único do art. $1^{\circ}$, que disciplina que todo o poder emana do povo e por fim no art. $5^{\circ}$, inciso XXXV, que cuida da apreciação, pelo poder judiciário, de lesão ou ameaça de lesão a direito.

Mas no âmbito da administração tributária federal, exemplificativamente, podemos citar o artigo $2^{\circ}$ da Lei 9.784/99, que traz a positivação da necessidade de motivação, vejamos:

Art. 2o - A Administração Pública obedecerá, dentre outros, aos princípios da legalidade, finalidade, motivação, razoabilidade, proporcionalidade, moralidade, ampla defesa, contraditório, segurança jurídica, interesse público e eficiência.

VI - adequação entre meios e fins, vedada a imposição de obrigações, restrições e sanções em medida superior àquelas estritamente necessárias ao atendimento do interesse público.

Nesse diapasão, podemos afirmar que tanto na produção de atos administrativos discricionários quanto na construção da norma a ser aplicada ao caso concreto, que se traduzira em ato administrativos, não há que se olvidar da necessidade de motivação desse ato.

São demasiadas as questões e dificuldade ligadas aos termos jurídicos indeterminados. Mesmo porque, operacionalizar um sistema escrito de normas inclui a dificuldade da própria língua, e ao se codificar o dever ser tropeça-se também na inexatidão das ações e reações humanas.

Na dinâmica social, em que sempre o fato precede o direito, é impossível criar enunciados de forma a atenderem sempre, a todas as situações tornando-as jurídicas. $\mathrm{Na}$ verdade, utilizando-se uma linha de pensamento que Viehweg ${ }^{106}$ demonstra, o direito possui noções chaves, quais sejam, aquelas que a significação depende do contexto em que aparecem, podendo assim variar de acordo com os problemas a serem solucionados, sendo a indeterminação não um defeito, mas um traço de linguagem.

A discricionariedade administrativa não é elemento que implica o princípio da eficiência de modo a tornar o ato ineficiente ou eficiente, desde que o ato exarado o seja de

${ }^{106}$ VIEHWEG, Theodor. Tpoia e Giurisorudenza. Milão: Giuffré, 1962. p.23 
modo eficiente o regime jurídico aplicado à administração bem como o dever da produção de resultado eficiente no atendimento das necessidades públicas.

\section{REFLEXOS DO PRINCÍPIO DA EFICIÊNCIA NA OBTENÇÃO DE RECEITA E NA DESPESA PÚBLICA}

3.1. O dever de o Estado planejar a atividade financeira e o princípio da eficiência como parâmetro de qualidade da atividade do Estado obter receita tributária e efetivar despesa pública

A matéria sobre orçamentos públicos é considerada norma geral de Direito Financeiro nos termos do artigo 24 , inciso II e $\S 1^{\circ}$ da $\mathrm{CF} / 88$, cujo regramento está contido na lei 4.320, de 17 de março de 1964, que estatui normas gerais de Direito Financeiro para elaboração e controle dos orçamentos e balanços da União, dos Estados, dos Municípios e Distrito Federal, cumpre mencionar que foi recepcionada pela $\mathrm{CF} / 88$ como lei complementar.

As normas contidas na lei orçamentária geral não excluem as demais que possam ser promulgadas pelos Estados, Distrito Federal e Municípios, em sua competência concorrente, de modo a criar restrições maiores ao orçamento público e complementares às normas nela presentes.

A elaboração da peça de orçamento público obedece a critérios jurídicos rígidos em relação à obtenção de receitas e alocações e forma de gastos (despesas),submetida a diversas etapas de produção normativa anteriores, que vão desde a elaboração do planejamento plurianual, criação da lei de diretrizes orçamentárias, até a criação da lei orçamentária, de modo que o orçamento passou de peça de natureza contábil para se tornar instrumento de efetivo controle da sociedade sobre as finanças públicas.

O professor Régis de Oliveira elenca alguns aspectos da Lei Orçamentária Anual ${ }^{107}$ :

- político, porque revela desígnios sociais e regionais, na destinação das verbas;

\footnotetext{
${ }^{107}$ OLIVEIRA, Regis Fernandes. Curso de Direito Financeiro. 3a . ed. São Paulo: Revista dos Tribunais,2010. p.305. v. 1.
} 
-econômico, porque manifesta a atualidade econômica;

- técnico com o calculo de receitas e despesas;

-jurídico: pelo atendimento as normas constitucionais e legais.

São peças financeiras obrigatórias, nos termos do artigo 165 da CF/88 : (i) Orçamento, (ii) Lei de Diretrizes Orçamentárias - LDO; (iii) Plano Plurianual; são as peças nas quais são normatizados os Programas de Trabalho de Governos e a política econômico-financeira. Compõem o Orçamento Público (art. $165 \S 5^{\circ}$ da CF/8) : a) orçamento fiscal; b) orçamento de investimento das empresas em que a União,direta ou indiretamente, detenha maioria de capital social com direito a voto; c) o orçamento da seguridade social.

Em vários momentos o plexo de normas gerais de Direito Financeiro fazem a prescrição de que no orçamento anual as receitas e as despesas devem se apresentar classificadas de modo a identificar o programa de trabalho do governo e a política econômicofinanceira (art. $2^{\circ}$ da lei 4.320/64).

$\mathrm{O}$ comando legal mencionado demonstra a necessidade de que haja a identificação e a possibilidade de estabelecimento da relação de pertinência entre a alocação da receita, a despesa efetivada e a evidencia imediatamente aferível de que esta a atender o planejamento efetuado e que deve ser conforme as prioridades estabelecidas pela Constituição Federal, sem prejuízo das análises referente à eficiência do gasto.

O modelo orçamentário brasileiro é definido na Constituição Federal de 1988, compõe-se de três instrumentos: o Plano Plurianual - PPA, A Lei de Diretrizes Orçamentárias - LDO e a Lei Orçamentária Anual - LOA, vejamos:

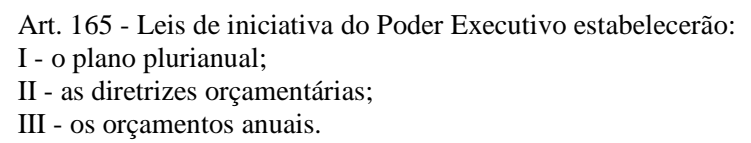

O Plano Plurianual possui vigência de quatro anos, tem como função estabelecer as diretrizes, objetivos e metas de médio prazo da administração pública. A lei de Diretrizes Orçamentária é elaborada anualmente para enunciar as políticas públicas e respectivas prioridades para o exercício seguinte. A lei Orçamentária Anual possui como principais objetivos estimar a receita e fixar a programação das despesas para o exercício financeiro.

Assim, a LDO ao identificar no PPA as ações que receberão prioridade no exercício seguinte torna-se o elo entre o PPA, que funciona como um plano de médio prazo do governo, 
e a LOA, que é o instrumento que viabiliza a execução do plano de trabalho do exercício a que se refere.

De acordo com a Constituição Federal, o exercício da função do planejamento é um DEVER do Estado, tendo caráter determinante para o setor público e indicativo para o setor privado: "Art. 174. Como agente normativo e regulador da atividade econômica, o Estado exercerá, na forma da lei, as funções de fiscalização, incentivo e planejamento, sendo este determinante para o setor público e indicativo para o setor privado".

Assim o planejamento expresso no Plano Plurianual assume a forma de grande moldura legal e institucional para a ação nacional, bem como para a formação dos planos regionais e setoriais. O $\S 1^{\circ}$ do inciso XI do artigo 167 da Constituição Federal é um argumento forte em relação à importância que os constituintes deram ao planejamento no Brasil, vejamos:

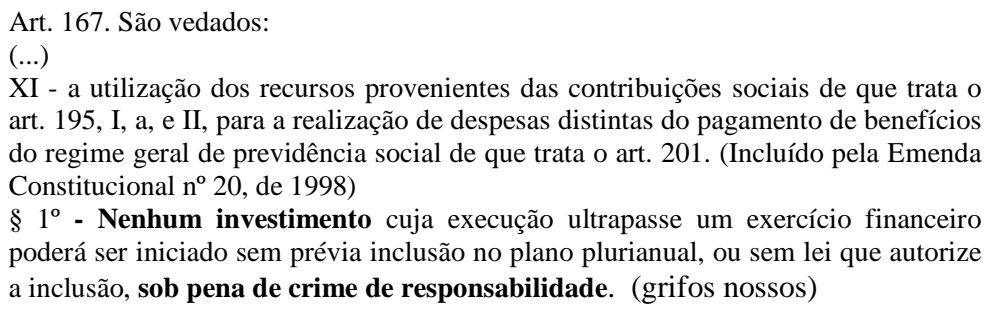

Assim podemos inferir que os instrumentos normativos para instrumentalizar o planejamento do Estado e que atendam os desígnios constitucionais estão normatizados, definidos e devem ser utilizados, e a análise detida do plexo normativo e das peças financeiras permite aferir o grau de planejamento, sendo certo que esse planejamentos devem ser submetidos ao crivo do princpio da eficiencia em suas tres dimensoes, o que quer significar a análise da formulaçao do planejamento, execução do planejamento, a execução desse planejamento.

A propósito do dever de planejar, é inerente a esse dever contingenciar e considerar o risco financeiro nas demandas que estão sendo discutidas no poder Judiciário e expressam risco alto de sucumbência, devendo para esse fim ser prevista a despesa.

Sendo certo que um ponto importante na questão da política fiscal é a corrente renúncia de receitas por intermédio de benefícios fiscais, visto poder acarretar efeito danoso as finanças pública, que sujeita o ente federado, ou qualquer ente público, a regras disciplinadoras. Nesse sentido o avanço se deu em razão da promulgação da Lei de Responsabilidade Fiscal - Lei Complementar $n^{\circ}$ 101, de 04/05/2000 - (LRF), de modo que 
além de respeitar as prescrições da LDO, os entes públicos devem: (a) estimar o impacto orçamentário financeiro no exercício inicial de sua vigência e nos dois seguintes; (b) demonstrar que a renúncia delas decorrente foi considerada ao se estimar a receita do orçamento e que não afetará as metas de resultados fiscais previstas na LDO; (c) prever medidas de compensação nos três exercícios já referidos, podendo ser através de: (c.1) elevação de alíquota, ampliação da base de cálculo ou novos tributos ou contribuições, sendo que nos dois últimos casos o benefício só entrará em vigor após a ocorrência do aumento da receita. Estas medidas deverão observar ainda, o princípio da anterioridade, nos termos do Código Tributário Nacional.

Importante ressaltar que o planejamento fiscal é fundamental para o Estado garantir a condução responsável da política fiscal e a provisão de recursos públicos de qualidade e eficiência. Assim deve o Estado, Poder Executivo, de forma transparente, apresentar a situação fiscal corrente, estabeleces seus objetivos e estratégias, identificar riscos às finanças públicas e adotar as melhores práticas de avaliação, acompanhamento e execução das políticas públicas.

\title{
3.2. Políticas Públicas - premissas
}

A definição de políticas públicas, segundo Bucci $^{108}$ : programas de ação governamental "visando a coordenar os meios à disposição do Estado e as atividades privadas, para a realização de objetivos socialmente relevantes e politicamente determinados, num dado espaço de tempo".

Celina Souza ao tratar do tema das políticas públicas, indica as caraterísticas desse instrumento:

\begin{abstract}
A política pública permite distinguir entre o que o governo pretende fazer e o que, de fato, faz; A política pública envolve vários atores e níveis de decisão, embora seja materializada através dos governos, e não necessariamente se restringe a participantes formais, já que os informais são também importantes. A política pública é abrangente e não se limita a leis e regras. A política pública é uma ação intencional, com objetivos a serem alcançados. A política pública, embora tenha impactos no curto prazo, é uma política de longo prazo. A política pública envolve processos subsequentes após sua decisão e proposição, ou seja, implica também implementação, execução e avaliação ${ }^{109}$.
\end{abstract}

\footnotetext{
${ }^{108}$ BUCCI, Maria Paula Dallari. As políticas públicas e o Direito Administrativo. Revista Trimestral de Direito Público. São Paulo, Malheiros, n. 13, p. 140, 1996.

${ }^{109}$ SOUZA, Celina . Políticas Públicas uma revisão de literatura. Revista Sociologias, Porto Alegre, ano 8, $\mathrm{n}^{\circ}$ 16 , p. 36, jul/dez 2006
} 
Assim temos que as políticas públicas estabelecem direito subjetivo público a prestações positivas do Estado como direitos fundamentais possuem jurisdiciabilidada a) aceitação da possibilidade de concretização judicial de direitos fundamentais (judicialização de políticas públicas), independentemente de criação de lei pelo Poder Legislativo, como conseqüência do aumento da força normativa da Constituição, da aplicação direta e imediata (máxima efetividade) dos direitos fundamentais (art. $5^{\circ}, \S 1^{\circ}$, da Constituição Federal de 1988), a dicotomia se instala porque o Estado busca ativamente um fim, mas se estabelece uma relação dilemática entre a viabilização pelo Estado das prestações positivas garantam o mínimo existencial e os recursos públicos limitados que impõe a reserva do possível.

\subsubsection{O Poder Judiciário e as Políticas Públicas}

A visão tradicional era de que os direitos sociais, que exigem uma atuação positiva do Estado configuravam normas programáticas, cuja implementação através de políticas públicas fica a critério do Executivo/Legislativo, não se permitindo a intervenção judicial sob pena de ofensa ao princípio da Separação dos Poderes.

Essa visão impõe que as escolhas trágicas ou "macrojustiça" fique a critério do Legislativo e do Executivo na elaboração e execução orçamentária e o Poder Judiciário faria apenas a "microjustiça", em que apenas resolve conflitos individuais aplicando a lei ao caso concreto, isso porque não teria condições de analisar conseqüências globais que envolvem as "escolhas trágicas".

Direitos sociais são indispensáveis à dignidade da pessoa humana, assim Judiciário deve garantir o "mínimo existencial" de cada um destes direitos, essa seria uma visão progressista de análise da função do Poder Judiciário, isso porque temos, modernamente, o Poder Judiciário como Guardião da Constituição, essa visão acarreta consequente preponderância sobre demais Poderes, cumpre mencionar que as políticas públicas postas na CF/88 limitam a discricionariedade do Administrador Público e a inércia do Estado em fazer valer os direitos prestacionais acarretaria "processo informal de mudança da Constituição".

A posição implica determinadas conseqüências, dentre elas confere ao Judiciário o poder de intermediar as relações com os demais poderes e insere o juiz do juiz como elemento partícipe do sucesso ou do fracasso do Estado e conceder direitos prestacionais, constitui o Poder Judiciário como legisladores positivos ("sentenças aditivas”), captura do orçamento 
recursos em ração da disputa pela fruição (judicialização dos Direitos Sociais); por fim impõe a fruição de direitos sociais coletivos (devem ser ofertados a todos igualmente) em direitos sociais coletivos de fruição individual ${ }^{110}$.

A possibilidade da discussão de políticas públicas no judiciário é conhecido pela expressão "ativismo judicial", faz nascer a discussão legitimidade do Poder Judiciário em ofertar decisões em matéria de políticas públicas, dada a inexistência de mandato democrático.

Mas não há que se esquecer de que a lide nasce de uma pretensão resistida, ou seja, de uma ameaça ou lesão a um direito, dessa maneira se inexiste a política pública para o atendimento de determinado direito fundamental o Poder Legislativo deve providenciar a elaboração da política, caso exista a política deve haver determinação para o cumprimento, conforme analisamos no subtítulo a seguir.

3.2.2. Separação de Poderes e Controle de Constitucionalidade alteração do papel do Poder Judiciário

A função historicamente atribuída ao Poder Judiciário cingia-se a pacificação de conflitos e limitação dos demais poderes para assim garantir o exercício de direitos civis e políticos, em razão das transformações do constitucionalismo moderno, conforme a seguir:

a) cabe ao Poder Judiciário exercer o controle de constitucionalidade das leis, que se cristalizou, notadamente, em razão da decisão prolatada pela Suprema Corte Americana no caso Marbury vs Madison (1803); O legislador brasileiro não se afastou das premissas fixadas pela doutrina Americana e também decidiu positivar a possibilidade do controle da constitucionalidade das leis, desde 1891, em que a Carta Política previa a possibilidade do controle de constitucionalidade difuso, o modelo de controle foi se aperfeiçoando, durante a edição das cartas posteriores, até a promulgação da Constituição Federal de 1988, que consolida o poder conferido ao Supremo Tribunal Federal de julgar a constitucionalidade das leis, via controle difuso e concentrado, cumpre mencionar que a Carta Magna também ampliou o rol de legitimados para propositura da ADIN.

\footnotetext{
${ }^{110}$ A respeito desses efeitos consultar: CHAYES,Abram. The role of the judge in public law litigation. Harvard Law Review, n 7, v. 89, 1976.
} 
b) opção do legislador constitucional em positivar princípios e valores fundamentais como componentes normativos da ordem jurídica;

c) Mandado de Injunção; A Constituição Federal de 1988, ao inserir a expressão "Estado Democrático de Direito", incluiu algumas alterações que afetam diretamente o papel do Poder Judiciário. Institutos, como o mandado de injunção, colocam em xeque o dogma da separação dos poderes, na medida que o Poder Judiciário pode defrontar-se, em qualquer instância, não com um pedido de resolução de conflito direto, mas sim de pedido de "criar" o direito, quando o Poder Legislativo foi omisso.

Dessa forma, o Poder Executivo além de ajustar seu plano político aos players políticos, teve que se preocupar em não infringir a Constituição por ação ou omissão. De maneira simplificada essa é a síntese do cenário que assentou o sistema político (democracia) e seus novos guardiões (a Constituição e os juízes).

O resultado desse cenário pode ser observado no judiciário, em que se extrai características específicas em relação às demandas nas quais se discute direitos afetos às políticas públicas. Segundo Vallinder, nesse fenômeno é possível observar duas características marcantes:

\footnotetext{
a) Disposição dos Tribunais no sentido de expandir o escopo das questões sobre as quais devem formar juízos jurisprudenciais (antes reservadas ao Executivo e Legislativo);

b) $\mathrm{O}$ interesse de políticos e autoridades administrativas em (a) adotar procedimentos semelhantes ao judicial e (b) considerar os parâmetros jurisprudenciais em suas deliberações ${ }^{111}$.
}

A disposição dos Tribunais em discutir os temas afetos às políticas públicas prescinde necessariamente de provocação, em razão do princípio da inércia da jurisdição, mas ao ser instado a decidir o judiciário superou o argumento de que estaria impedido de analisar o pedido invocando como fundamento o princípio da separação de poderes.

O controle judicial das políticas públicas somente se faz possível em razão do entendimento de que a política pública fora incorporado ao conceito de ato de governo, sendo assim, não goza do predicado de imunidade em relação ao controle jurisdicional, diferindo

\footnotetext{
${ }^{111}$ TATE, Neal; VALLINDER, Torbjorn. The global expansion of judicial power: the judicialization of politics. New York, New York University Press, 1995. In CASTRO, Marcos Faro de. O Supremo Tribunal Federal e a Judicialização da Política. Revista Brasileira de Ciências Sociais, 12, 34, p. 148, 1997.
} 
dos atos essencialmente políticos, cuja vedação de análise pelo judiciário é possível, mas somente se esses atos não violarem direitos subjetivos ${ }^{112}$.

Analisar a Constituição à luz de seu conteúdo e, nesse sentido, destacar o importante papel do Judiciário em sua interpretação. No tocante à interpretação constitucional, Häberle (1996) afirma que as influências, expectativas, pressões sociais a que o juiz está exposto, contêm um fragmento de legitimação e impedem a arbitrariedade da interpretação. Isto porque o povo não é apenas fonte de legitimidade democrática no dia das eleições, mas também consiste em fonte de legitimação como partido político, como opinião pública, como grupo de interesses, como cidadãos.

Trata-se de visualizar a democracia como democracia dos cidadãos e não como democracia popular, no sentido rousseauniano, que seria mais restrito, pois coloca o povo em último lugar, por intermédio dos direitos fundamentais. Na concepção da democracia dos cidadãos, o povo atua em todas as partes, universalmente, em muitos níveis, por muitos motivos e de muitas formas.

A Constituição Federal de 1988 sinaliza nesse sentido de que a cidadania não se esgota na escolha dos candidatos. Dessa feita, novos campos de ação, em que o direito não tem como atuar, são propostos.

O Estado não é ente isolado no quadro social: ele age e interage mediante a atuação social, a atuação popular, a atuação de grupos, etc. Esses novos mecanismos públicos ou privados ("público" não é sinônimo de "estatal") de encaminhamento de reclamações, queixas, soluções, sugestões é que caracterizam o Estado Democrático de Direito. Alguns exemplos: direito às informações (art. $5^{\circ}$, XXXIII, CF/88), direito de petição (art. $5^{\circ}$, XXXIV, a, CF/88), direito à publicidade, a hábeas corpus (art. 5, LXVIII, CF/88), a ação popular (art. $5^{\circ}, \mathrm{LXXIII,} \mathrm{CF/88),} \mathrm{a} \mathrm{mandado} \mathrm{de} \mathrm{segurança} \mathrm{individual} \mathrm{(art.} \mathrm{5º} \mathrm{LXIX,} \mathrm{CF/88)} \mathrm{e} \mathrm{coletivo} \mathrm{(art.}$ $5^{\circ}, \mathrm{LXX}, \mathrm{CF} / 88$ ), a hábeas data (art. 5, LXXII, CF/88), à iniciativa popular (art. 61, § $2^{\circ}$ ), a mandado de injunção (art. 5, LXXI, CF/88), a controle judicial (art. 5 $, \mathrm{XXXV}, \mathrm{CF} / 88$ ), a controle da constitucionalidade das leis, direta ou indiretamente (na indireta, são partes legítimas o Conselho Federal da Ordem dos Advogados do Brasil, os partidos políticos representados no Congresso, as confederações sindicais - art. 103, CF/88). São exemplos da defesa de uma participação efetiva, direta e indireta, na vida "pública" e não só na "política" (sentido partidário).

\footnotetext{
${ }^{112}$ MEDAUAR, Odete. Controle da Administração Pública. São Paulo: RT, 1993. p.159-180.
} 
A atuação conforme a Constituição somente se realiza se restar respeitada a dignidade da pessoa humana (art. $1^{\circ}, \mathrm{CF}$ ) que se afigura como diretriz nuclear na Lei Maior brasileira e se os objetivos constitucionais (art. $3^{\circ}, \mathrm{CF}$ ) de construir uma sociedade livre, justa e solidária, com amplo desenvolvimento nacional, redução da pobreza e desigualdades e promoção do bem de todos forem atendidos.

As relações estabelecidas são complexas e Misabel Derzi aponta para uma crise jurídica, desencadeada pelo questionamento da legitimidade da regra como instrumento de controle e de regulação, agravada por uma dogmática perplexa e cada vez mais desestruturada pela realidade mutante, complexa e pluralista, passa a ser denominada "crise da modernidade jurídica”. Assim explica Marc Pelletier, os novos paradigmas:

\begin{abstract}
A complexidade e o pluralismo com os quais são confrontadas as sociedades diferenciadas deixarão em suspenso as representações tradicionais do sistema jurídico. A metáfora da pirâmide kelseniana do ordenamento jurídico cederá, por isso, o lugar a uma representação do sistema jurídico centrado sob o modelo de uma rede entrelaçada. À verticalidade de uma ordem jurídica imposta sucederiam a circularidade e a horizontalidade de um tecido normativo negociado, na medida em que as considerações de eficiência das políticas públicas tendem a disputá-lo à validade formal do direito. A fim de considerar esse fenômeno, certos autores se propõem a recorrer a um novo conceito: a pós -modernidade. ${ }^{113}$
\end{abstract}

Mas não há que se olvidar que os direitos fundamentais devem receber o tratamento jurídico que corresponde à sua qualidade de "fundamento funcional da democracia", porque é só através do exercício individual dos direitos fundamentais que se realiza um processo de liberdade que é elemento essencial da democracia.

Assim nos posicionamos de que as políticas públicas que perseguem a consecução dos fins constitucionais devem ser perseguidas também no âmbito do Judiciário, ainda que interfiram na atividade financeira do Estado na dimensão do planejamento financeiro e interfira no gasto público, cuja despesa não foi prevista no orçamento, isso porque o direito material à fruição dos direitos fundamentais são indisponíveis, na medida do mínimo existencial, e encontra limitação apenas na reserva do possível, excluídas as limitações não formal (falta de previsão orçamentária)

\footnotetext{
${ }^{113}$ PELLETIER, Marc. Existe-t-il une Approche Post-Moderne de la Fiscalité? L'Exemple de la CSG. In L'Imôt, Archives de Philosophie Du Droit, Tome 46. Paris: Dalloz, 2002, p. 211-212 In DERZI, Misabel Abreu Machado.A praticidade, a Substituição Tributaria.Tributos e direitos fundamentais coord Octavio Campos Fischer,São Paulo, Dialética,2004.p261
} 


\section{O PRINCÍPIO DA EFICIÊNCIA NO AMBIENTE NORMATIVO DA ATIVIDADE FINANCEIRA DE OBTENÇÃO DE RECEITAS TRIBUTÁRIAS}

A atividade de arrecadar tributo esta marcada pela relação Estado versus cidadãocontribuinte (interesse público versus interesses privados), o interesse público primário nessa relação, assim como em todas as relações de natureza pública é a realização do interesse comum (bem estar), sendo certo que o secundário é o interesse econômico.

Que em uma síntese dentro do marco teórico dos fundamentos de igualdade, liberdade e justiça, o Estado pode instituir tributos (consentimento pelo pacto social), apropriando-se do patrimônio pessoal dos cidadãos (em detrimento ao direito de propriedade) desde que essa atividade atenda aos interesses comuns, desde que não viole garantias e direitos individuais de proteção do cidadão contribuinte, a quem é permitido fazer tudo que a lei não proíbe.

O princípio da eficiência impõe ao Estado a necessidade do desenvolvimento de um planejamento eficiente e ação eficiente ${ }^{114}$, para eficientemente tributar, sob esse aspecto temos que a legalidade é : (a) o fundamento da atividade de planejar e instituir tributos e, esta sujeita (b) a limitação que decorre (c.3) do estabelecimento de direitos e deveres materiais e formais aos integrantes dessa relação que nesse caso entendemos ser os direitos e garantias individuais do cidadão contribuinte; (d) finalidade de arrecadar conforme o interesse público, nos limites direitos e garantias fundamentais do contribuinte.

\footnotetext{
${ }^{114}$ Nota do autor: Sendo certo que do ponto da concretude o agir estatal se manifesta por meio do (i) planejamento fiscal e estabelecerá metas a serem alcançadas; o (ii) agir concretamente para o alcance dessas metas, que pressupõe : (a) elaboração de política fiscal que pautará a atividade legislativa para a instituição dos tributos e obrigações acessórias tributárias, que no sentido estrito não estará adstrito a legalidade por ser metajurídico; (b) criação de meios eficientes de execução desses comandos legais para instituir e efetivar a arrecadação da receita tributária, nesse ponto é imperioso o cotejamento com o princípio da legalidade, visto que a criação de tributos esta subsumida à legalidade genérica e à legalidade estrita. $\mathrm{O}$ primeiro crivo da eficiência é elaborar o texto normativo em conformidade com a legalidade formal de acordo com o conteúdo da Lei Complementar 95 de 26 de fevereiro de 1998, em seguida deve-se passar a análise se o texto legal não afronta disposição expressa constitucional ou lei infraconstitucional e, em especial, se não fere as disposições constitucionais que limitem o poder de tributar, e as demais garantias asseguradas ao contribuinte; d) disponibilização pelo Estado de meios eficientes de discussão e revisão desse "modo de agir" complexo na atividade financeira de perceber receita (legislar e executar as leis), constituindo a garantia do Estado de Democrático de Direito de acesso à eficiente revisão administrativa e judicial dos atos exarados pelos poderes Legislativo, Executivo e Judiciário. Cumpre mencionar que se trata de garantia constitucional, no entanto, a revisão administrativa pode se dar pela via do controle dos próprios atos, etapa anterior a litigância (administrativa ou judicial). Do ponto de vista do princípio da eficiência impende ressaltar que a revisão seja ela administrativa ou judicial decorre da ineficiência em qualquer fase das ações Estatais, sendo certo que em relação à revisão administrativa ou judicial resta afastada a ineficiência Estatal em qualquer das fases nos casos de evidente má-fe do administrador no manejo da via revisional para a discussão de seus direitos materiais ou formais.
} 
Sabemos que fonte de recursos para o financiamento da atividade Estatal, em sua parcela mais siginificativa, advém de receitas derivadas, ou seja, a tributação da atividade do particular, que detenha expressão econômica.

O sistema jurídico tributário brasileiro se subsume ao princípio da capacidade contributiva expresso no artigo $145 \S 1^{\circ}$ que determina que sempre que possível, os impostos terão caráter pessoal e serão graduados segundo a capacidade econômica do contribuirte, em que se infere que aquele que detém a maior capacidade econômica deve contribuir mais para a manutenção dos serviços públicos.

Regina Helena Costa em sua obra Praticabilidade e Justiça Tributária ${ }^{115}$ cita Joseph Isensee que afirma: “o destino do imposto está ligado à igualdade” posto que aponta o princípio da capacidade contributiva como critério ético da imposição tributaria, porquanto responde aos reclamos da justiça tributária, voltada à minimização das disparidades sociais e econômicas.

Tendo em vista os predicados do princípio da eficiência é imperiosa uma atuação responsável do Estado ao legislar sobre matéria tributária, cujo mal desempenho, implica em resultados desastrosos para a manutenção saudável das finanças publicas e privadas. Assim analisaremos por uma amostragem com base em critérios de escolha, alguns princípios que entendemos serem relevantes para o tema do princípio da eficiência.

O primado da capacidade contributiva é a aptidão de caráter econômico de o cidadão concorrer aos gastos públicos de forma isonômica aos demais, a ser considerado no exercício da atividade financeira.

A Constituição Federal Brasileira impõe e protege os axiomas do livre exercício da atividade econômica, da propriedade privada e da restrição da intervenção do Estado no domínio econômico.

A proteção à propriedade privada é garantia individual prevista no artigo $5^{\circ}$ da Constituição Federal, cuja menção no artigo 170 , quando trata da Ordem Econômica, visa garantir que essa ordem econômica repouse sobre aquele instituto, ou ainda que nos fins da

${ }^{115}$ COSTA, Regina Helena. Praticabilidade e Justiça Tributária. Sao Paulo: Malheiros. 2007. p. 113. 
última (justiça social e existência digna) realizar-se-á por meio da propriedade privada ${ }^{116}$, Schoueri aduz:

\begin{abstract}
A propriedade privada revela-se como algo não a ser tolerado pelo Estado, mas como um princípio da sua Ordem Econômica. Enquanto tal, deve ser fomentado pelo Estado. De modo que o que se espera é uma atuação positiva do Estado, marcada pela promoção e incentivo à propriedade privada.
\end{abstract}

Importante mencionar que a norma tributária tanto na imposição de exações quanto na imposição de deveres instrumentais deve respeito à manutenção da propriedade privada, ainda quando a norma tributária exacional cumpre papel indutor de conduta (tributos com fins extrafiscais) isso porque a norma tributária indutora encontra limites muito mais rígidos que aquele imposto à norma tributária simplesmente arrecadatória.

Isso porque utilizar a norma tributária como instrumento de intervenção no domínio econômico (indução de comportamento) pode inviabilizar a atividade econômica livre daquele que fora atingido.

Em sua obra, Karl Heinrich ${ }^{117}$ afirma que se o Estado no seu ato de intervenção, põe em ameaça parte do patrimônio particular, pode se tornar contestável a própria intervenção Estatal.

A Ordem Econômica esta fundada na propriedade privada, livre iniciativa e na livre concorrência que baliza a ordem econômica e fundamenta o próprio Estado Democrático de Direito.

A Constituição manda, no art. 173, 4 , que a lei reprima "o abuso do poder econômico que vise à dominação dos mercados, à eliminação da concorrência e ao aumento arbitrário de lucros".

Como a Constituição o poder econômico, em si, é um fenômeno natural na dinâmica de produção e circulação da riqueza, de modo que prescreve a repressão ao abuso desse poder, mediante elaboração da lei.

O abuso juridicamente considerado é desvio de finalidade, o que quer significar nesse contexto, genericamente o uso do poder econômico de modo a prejudicar e até inviabilizar a liberdade, e a justiça econômicas.

\footnotetext{
${ }^{116}$ SCHOUERI, Luis Eduardo. Direito Tributário. São Paulo: Saraiva, 2011.

${ }^{117}$ Idem, ibidem. p. 328
} 
Tercio Sampaio Ferraz Junior ${ }^{118}$ afirma:

\begin{abstract}
A busca do lucro, enquanto condiciona e possibilita a acumulação de capitais, explica o aumento da dimensão da empresa. No regime de concorrência, este processo pode conduzir a ajustes, coalizões, fusões, incorporações ou integrações, como instrumentos de competição. Em consequência, o fenômeno do poder econômico não é uma exceção no jogo do mercado, mas um dado virtualmente constante das relações econômicas. Em outras palavras, a Constituição aceita a fazer parte da economia de mercado o uso estratégico do poder afim de obter posições de maior predominância no interior de sua estrutura. $O$ abuso ocorre quando, neste uso estratégico, estamos diante de um desvio de finalidade. E este desvio a Constituição define especificamente pela dominação dos mercados, pela eliminação da concorrência e pelo aumento arbitrário dos lucros. Dominação é mais do que posição de predominância. É, por meios ardilosos, bloquear a renovação do mercado, impedindo o advento de novas forças e a expansão das existentes. Eliminação da concorrência é mais do que competir, tentando, estrategicamente, suplantar os demais. É atentar contra a própria estrutura do mercado, fazendo da competitividade uma aparência de competitividade, da concorrência um jogo previamente combinado, em que as partes abram mão da sua liberdade em troca de uma vantagem que as tiraniza. Aumento arbitrário de lucros é mais do que busca do lucro e a acumulação de capital. É obtenção ardilosa de vantagens desproporcionais aos custos do investimento, conquistados a partir de posições de predominância naturais ou artificialmente alcançadas. (grifos nossos)
\end{abstract}

A Constituição protege a livre concorrência, cujo princípio é afirmado no art. 170, IV ,sempre com o objetivo de reprimir o abuso do poder econômico.

Importante compreender que a proteção da livre concorrência não assegura que os agentes econômicos concorram sem qualquer interferência do Estado, em verdade é antes uma garantia de que a concorrência deve ser alcançada, já que é pelo gozo da propriedade dentro da Ordem Econômica balizada pelos princípios da livre iniciativa e livre concorrência que é possível uma busca pela existência digna de todos.

A compreensão dessa relação de implicação permite-nos afirmar que a livre concorrência ganha feições de garantia positiva, de modo que a Ordem Econômica deve assegurar que a concorrência ocorra, não como um direito dos agentes que movimenta a economia, isoladamente considerado, mas da sociedade como um todo ${ }^{119}$.

Nesse ponto, é importante ressaltar a importância do comportamento dentro de limites éticos e eficientes, tanto dos agentes econômicos bem como do próprio Estado, dada a

\footnotetext{
${ }^{118}$ FERRAZ JÚNIOR, Tércio Sampaio. Revista dos Mestrandos em Direito da UFBA. Salvador, $\mathrm{n}^{\mathrm{o}}$ 2, pp. 65-74, jul/91-jun/92.

${ }^{119}$ SCHOUERI, Luis Eduardo. Direito Tributário. São Paulo: Saraiva,2011. p.211
} 
tamanha profusão de resultados que apenas uma medida/atitude do particular ou do Estado pode causar no mercado interno.

Tercio Sampaio Ferraz ${ }^{120}$ Junior sinalizou nesse sentido, vejamos:

\begin{abstract}
É preciso, pois, cuidar para que o desenvolvimento econômico ou técnico do sistema não seja comprometido por comportamentos dos agentes que, sem ser abusivos, podem levar à distorção, como o impedimento do afluxo de recursos a certos setores ou o bloqueio da possibilidade de expansão de concorrentes. Neste sentido, a Constituição, que declara o mercado interno como patrimônio nacional (art. 219), exige do Estado, como agente normativo e regulador da atividade econômica (art. 174), o exercício, na forma da lei, da função de fiscalização. A lei, aqui referida, reporta-se a prescrições de natureza regulativa, cujo escopo é o eficiente funcionamento do mercado. Entende-se, por esta via, que n Lei n8158/91 não cuide apenas de ilícitos e infrações, mas também mais amplamente de anomalias de comportamento, enquanto ocorrências possíveis na estrutura objetiva do mercado. O dever de o Estado, nestes casos, atuar preventivamente, a fim de obviar a ocorrência de situações prejudiciais a uma concorrência eficiente e, até mesmo, evitar as condições capazes de levar o agente ao abuso do poder econômico, é o supedâneo constitucional de sua função fiscalizadora. .(grifos nossos)
\end{abstract}

Nesse ponto temos que o Estado exerce papel de agente normativo e regulador, e tem a incumbência de gerir o mercado, como patrimônio nacional, mas sem prejudicar o direito da iniciativa privada na determinação das suas próprias políticas, pois, nesse caso, estaria o Estado, inconstitucionalmente, alterando o fundamento da Ordem Econômica (art. 170).

O Estado aqui mencionadas em face da defesa da concorrência deve praticar atos que vão desde a repressão até os meros protocolos de intenção não só a iniciativa privada, mas também as atividades econômicas do próprio Estado pelas suas empresas públicas, sociedades de economia mista e outras entidades, as quais, em tudo, estão sujeitas ao regime jurídico próprio das empresas privadas (art. $\left.173^{\circ} 1 \mathrm{a}\right)$, estando, ademais, vinculadas ao planejamento estatal (art. 174).

Os monopólios constitucionais (art. 177), que conferem à União, legitimamente, uma posição dominante devem respeito ao mercado e devem ter comportamento conformes ao princípio da livre concorrência, não lhes sendo lícito abusar do poder econômico nem provocar distúrbios no seu funcionamento eficiente.

A livre concorrência deve se harmonizar com os demais preceitos constitucionais, ou seja, não se pode defender a concorrência a custa da soberania nacional, do consumidor, do

\footnotetext{
${ }^{120}$ FERRAZ JÚNIOR, Tércio Sampaio. Revista dos Mestrandos em Direito da UFBA. Salvador, $\mathrm{n}^{\mathrm{o}}$ 2, pp. 65-74, jul/91-jun/92.
} 
meio ambiente, da redução de desigualdades regionais e sociais, da busca do pleno emprego, do tratamento favorecido às empresas nacionais de pequeno porte. E vice versa: nenhum desses princípios será defendido à custa da livre concorrência. Isto vale, obviamente, e $a$ fortiori, para o princípio da propriedade privada e o da sua função social (incisos II e III do art. 170).

A neutralidade fiscal decorre do respeito pela norma tributária exacional ou criadora de deveres instrumentais à livre concorrência. De modo que cabe ao legislador, previamente, a produção normativa no âmbito do Poder Executivo, como é o caso, ponderar os efeitos econômicos de suas medidas, utilizando-se das normas tributárias, como de outros meios que estiverem ao seu alcance para a indução do comportamento dos agentes econômicos, visando as finalidades próprias da intervenção econômica.

O mundo fenomênico não esta adstrito ao querer administrativo, antes de tudo está absorto por uma complexidade de eventos e variáveis, que o Estado tem o dever de prever, planejar e servir como indicativo para iniciativa privada (artigo 174, $1^{\circ} \mathrm{CF} / 88$ ), principalmente quando os critérios estão fixados pelo Ordenamento Jurídico. Isso não está no âmbito do mundo das ideias, tanto o é, que no âmbito administrativo o Tribunal Administrativo de Recursos Fiscal, órgão pertencente ao poder executivo federal, é reconhecida a importância da análise concreta se as práticas tributárias interferem na livre concorrência, vejamos:

IMUNIDADE - SUSPENSÃO - ATIVIDADE DESENVOLVIDA QUE FERE O PRINCÍPIO DA LIVRE CONCORRÊNCIA - INOCORRÊNCIA. A suspensão da imunidade sob o argumento de que a atividade desenvolvida pela entidade imunidade ofende o princípio da livre concorrência, no presente caso, não pode prosperar. À luz de entendimentos do Supremo Tribunal Federal, inclusive alguns do próprio Conselho de Contribuintes, e de grande parte da doutrina, se cumpridos os requisitos estabelecidos pelo art. 14 do CTN, não há que se impedir a fruição da imunidade, pois, como afirmado pelo Ministro Sydney Sanches, citado por Ruy Barbosa Nogueira, "A instituição de assistência social não está proibida de obter lucros ou rendimentos que podem ser e são, normalmente, indispensáveis à realização dos seus fins. O que elas não podem é distribuir os lucros. Impõe-se-lhes o dever de aplicar os rendimentos 'na manutenção dos seus objetivos institucionais"'. Ademais, se a atividade desenvolvida tem por finalidade auxiliar a cobrir o deficit da atividade principal da entidade imune, não é correto retirar, pura e simplesmente, a imunidade somente com o argumento em tese de que estaria ferido o princípio da livre concorrência. A ofensa a este deve ser provada e não apenas alegada, sob pena de agredir-se a supremacia constitucional. Número do Processo 13133.000025/99-62 Órgão Julgador Sétima Câmara/Primeiro Conselho de Contribuintes Contribuinte $\begin{array}{llll}\text { Data da Sessão } & 11 / 06 / 2003 & \text { Relator(a) } N^{\circ} & \text { Acórdão }\end{array}$ 107-07197. 
Assim, considerando conjuntamente o direito a propriedade privada, capacidade contributiva e livro mercado temos pelo valor igualdade, segurança jurídica, e legalidade tributária inerente ao sistema normalizado um sinalizador de eficiência no cumprimento dos desígnios constitucionais.

Em razão da atualidade não podemos deixar de tratar da questão do excesso de obrigações acessórias e transparência fiscal.

Com relação às obrigações acessórias a doutrina é entende que os deveres instrumentais devem observar o princípio da legalidade, defendendo que somente poderão ser exigidas prestações positivas ou negativas, no interesse da arrecadação ou fiscalização dos tributos, se houver lei ${ }^{121 .}$

James Marins, no mesmo sentido, entende que a referência à expressão "legislação tributária" não permite que se possa ignorar o princípio da legalidade. Segundo aponta, os atos infralegais não podem criar obrigações ou sujeições aos fiscalizados. "Os instrumentos secundários estão adstritos aos termos da lei, que determina a dimensão da interferência que pode atingir a esfera da liberdade e propriedade do fiscalizado" ${ }^{\text {122 }}$.

Esclarece Roque Carrazza ${ }^{123}$ ainda que :

\begin{abstract}
para cumprir seus deveres instrumentais, o contribuinte precisa mobilizar pessoal, adquirir livros, imprimir notas fiscais, possibilitar aos agentes do Fisco o exame de sua documentação, e assim por diante. Tais providências demandam tempo e dinheiro.

Além disso, pelo fato de o descumprimento dos deveres formais resolver-se em sanções de diversas espécies, inclusive pecuniárias, 'repugna ao senso jurídico que uma pessoa possa pagar multa com base no não acatamento de um dever criado por norma jurídica infralegal'. Por esses motivos, o autor não admite que a Administração Tributária indique os elementos essenciais dos deveres instrumentais tributários, pois isso seria o mesmo que lhes atribuir status de legislador, o que, sem dúvida, é impossível. Em síntese, sustenta que "os cidadãos não podem ter sua esfera de liberdade restringida, vale dizer, não podem ser compelidos a qualquer comportamento, positivo ou negativo, senão por meio de lei" (CARRAZZA, 2009, p. 351) ${ }^{124}$. (grifos nossos)
\end{abstract}

Regina Helena Costa ao analisar o tema da "privatização da gestão tributária" afirma:

\footnotetext{
${ }^{121}$ CARVALHO, Paulo de Barros. Curso de direito tributário. 21 a. ed. São Paulo: Saraiva, 2009. p. 329.

${ }^{122}$ MARINS, James . Direito Processual Tributário Brasileiro: Administrativo e Judicial. $4^{\text {a }}$. ed. São Paulo: Dialética, 2005. p 230.

${ }^{123}$ CARRAZZA, Roque Antônio. Curso de direito constitucional tributário. 25a. ed. São Paulo: Malheiros, 2009. p. 350

${ }^{124}$ Idem, ibidem. p.351.
} 
Dentro de uma noção maior de eficiência podemos extrair um sub princípio, qual seja, o da limitação de custos indiretos, segundo o qual há que se minimizar os custos indiretos, derivados das exigências formais necessárias para o cumprimento das obrigações tributárias. Seu conteúdo rechaça a imposição de deveres instrumentais tributários que se revelem demasiadamente custosos ao contribuinte, estimulando seu cumprimento e, consequentemente, comprometendo a eficiente

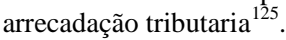

A respeito da ineficiência do Estado no exercício da atividade financeira tributária nada mais atual que a seguinte proposição de Adam Smith:

\begin{abstract}
A sua coleta pode requerer um grande número de funcionários (...) pode obstruir a iniciativa do povo (...) pode frequentemente arruiná-los (os contribuintes) e, assim, por fim ao benefício que a comunidade poderia ter recebido do emprego de seu capital (...) submetendo o povo a frequentes visitas e ao odioso exame dos coletores de taxas, pode expô-lo a muito trabalho desnecessário, vexame e opressão ${ }^{126}$.
\end{abstract}

O princípio da eficiência resta atendido no exercício da atividade tributária quando essa tem sucesso em realizar a máxima da tributação proposta por Adam Smith se desenvolvendo com a) igualdade (cujo corolário é o princípio da capacidade contributiva); b) comodidade e economia na cobrança, c) respeitando os direitos e garantias fundamentais do contribuinte, e mais ainda pela eficiente utilização dos recursos públicos.

Isso porque do ponto de vista da eficácia (i) planejar e estabelecer metas a serem alcançadas pela tributação, e o (ii) agir concretamente para o alcance dessas metas e necessariamente impende em (iii) aferir racionalmente a relação entre as metas alcançadas e a metas pretendidas, isso por avaliação de desempenho ou performance da tributação, que não esta adstrito a apenas arrecadar, posto que o que arrecadar não é um fim em si mesmo.

A dimensão da efetividade impõe a análise do impacto sociais e econômicos da instituição dos tributos, sem o qual não há como falar em tributação eficiente sob o aspecto do resultado, também é necessária a aferição da entender se uma tributação é eficiente do ponto de vista da eficiência-economicidade considerando a (i) o custo para sua instituição vs fiscalização e montante arrecadado.

\footnotetext{
${ }^{125}$ COSTA, Regina Helena. Praticabilidade e Justiça Tributária. São Paulo: Malheiros, 2007. p. 393.

${ }^{126}$ SMITH, Adam. Riqueza das Nações. Norberto de Paula Lima (Trad.) ed. cond. São Paulo : Folha de São Paulo, 2010. p.347. (Coleção Folha: Livros que mudaram o mundo. v.4).
} 
Aqui necessária se faz a ressalva a espécie tributaria contribuição, que tem como pressuposto de validade e legitimação a finalidade para qual foi instituída (por exemplo, as contribuições previdenciárias, são receitas destinas a custear as despesas da Previdência Social), aqui o juízo tríplice de análise impõe a aferição da destinação. Por intermédio de Emendas a Constituição Federal fora criada a desvinculação das receitas da União matéria de contribuições, que legalmente, altera a finalidade constitucionalmente privilegiada ${ }^{127}$, medida que interfere na legitimidade da manutenção das contribuições como meio de arrecadar receitas sem finalidade especifica, destoando do modelo originariamente desenhado pela Constituição Federal.

Assim concluímos que o interesse primário de atender as necessidades públicas perseguindo o bem estar comum, inclui a necessidade pública que possui o cidadão ser tributado de forma o eficiente na dimensão eficácia, efetividade e eficiência.

${ }^{127}$ Desvinculação de Recursos da União (DRU) - afasta as vinculações constitucionais de $20 \%$ de toda a arrecadação tributária brasileira. 


\section{O PRINCÍPIO DA EFICIÊNCIA NO AMBIENTE NORMATIVO DA ATIVIDADE FINANCEIRA NA ATIVIDADE FINANCEIRA DA DESPESA PÚBLICA}

A questão da eficiência a muito circunda as ciências humanas dentre elas, mais profundamente a Economia, que foi pioneira no desenvolvimento desse tema.

Conforme buscamos demonstrar o princípio da eficiência é vetor axiológico qualificativo do modo de agir da administração pública, no exercício da atividade financeira do Estado, o tema da eficiência prescinde de planejamento, ação e uma análise de performance da ação Estatal, da qual decorrerá um signo de resultado, que não necessariamente esta vinculado a questão da economicidade.

J. Rawls em sua obra Uma teoria da justiça, afirma que as instituições são justas quando não fazem distinções arbitrárias entre as pessoas na atribuição dos direitos fundamentais, e quando as leis definem um equilíbrio apropriado entre as reivindicações das vantagens da vida social que sejam conflitantes entre si. A similaridade e diferenças entre as pessoas são importantes na atribuição dos direitos e deveres, e especifica qual é a divisão de vantagens apropriadas;

Segundo o autor, o papel característico das concepções de justiça, conjunto de princípios correlacionados que objetiva identificar as considerações relevantes que determinam esse equilíbrio, em que o equilíbrio é o conceito de justiça, é especificar os direitos e os deveres fundamentais, e definir as parcelas distributivas apropriadas.

O modo como determinada concepção de justiça faz a especificação de direitos e deveres fundamentais e define as parcelas distributivas fatalmente influi nos problemas da eficiência, da coordenação e da estabilidade social, indiscutível, portanto, a influência dessas decisões na captação e na alocação de recursos financeiros para realização das despesas públicas.

A despesa pública, nas palavras de Aliomar Balieiro, tem duas concepções, vejamos:

Em primeiro lugar, designa o conjunto dos dispêndios do Estado ou de outra pessoa de direito público. Assim, nesse sentido, a despesa é parte do orçamento, ou seja, aquelas que se encontram classificadas todas as autorizações para gastos com várias atribuições e funções governamentais. Forma, por outras palavras, o complexo da distribuição e emprego das recitas para custeio dos diferentes setores da administração. Uma despesa pública é também, noutro conceito, a aplicação de 
certa quantia, em dinheiro, por parte da autoridade ou agente público competente, dentro de uma autorização legislativa, para execução de fim a cargo do governo, regulados pelo Direito Administrativo e, quase sempre, realizados segundo a técnica da Ciência da Administração ${ }^{128}$. (grifo do autor)

Ainda em trabalho recente, Correia Neto afirma haver significações ao termo gasto público ou despesa pública:

\begin{abstract}
Podemos apontar, pelo menos, seis significados diversos para o termo [gasto público ou despesa pública]: (1) o veículo normativo referente à totalidade de dispêndios estatais, em sentido global; (2) cada um dos veículos normativos que tenham por objeto dispêndios estatais, em seus diversos níveis de positivação, e o conteúdo dessas normas, seja este (3) os dispêndios globais ou (4) os dispêndios individualizados; (5) o documento que registra o pagamento e (6) o ato concreto de $\operatorname{pagar}^{129}$
\end{abstract}

A linguagem permite a veiculação de conceito distintos ao termo despesa pública, nesse trabalho, optamos por considerar o conceito de despesa pública na acepção dada por Aliomar Baleiro como "a aplicação de certa quantia, em dinheiro, por parte da autoridade ou agente público competente, dentro de uma autorização legislativa, para execução de fim a cargo do governo"

As despesas públicas podem ser analisadas sob diversos aspectos dentre eles: (1) ao objeto (militares, de justiça, diplomacia, etc.); (2) ao período temporal de autorização (problema de ordem orçamentária e política); (3) ao ponto de vista financeiro (noção de despesa pública, suas características em comparação com as despesas dos indivíduos, as causas de seu aumento e a medida que os gastos do governo gera uma sobrecarga sobre os indivíduos, a repartição das despesas entre o Estado e as localidades), no entanto, o traço que a distingue como objeto apartado de estudo é a concepção dada por Jèze: nos Estados modernos, "a despesa pública apresenta três elementos essenciais: 1. uso de uma soma de

\footnotetext{
${ }^{128}$ BALEEIRO, Aliomar. Uma introdução à ciência das finanças. 12 $2^{\mathrm{a}}$ ed. Rio de Janeiro, Forense, 1978 . p.06. ${ }^{129}$ CORREIA NETO, Celso de Barros. Orçamento público: uma visão analítica. São Paulo, II Prêmio SOF de Monografias, 2008. Disponível em <http://www.esaf.fazenda.gov.br/premios/premios-1/premios/vii-premiosof-de-monografias/2o-premio-sof-2008/tema-2-3o-lugar/at_download/file>. p. 28-29. Acesso em 10/10/2012.

${ }^{130}$ BALEEIRO, Aliomar. Uma introdução à ciência das finanças. $12^{\mathrm{a}}$ ed. Rio de Janeiro, Forense, 1978. p.06.
} 
dinheiro; 2. por funcionários públicos e em nome de um patrimônio administrativo; 3. para a satisfação de uma necessidade pública ${ }^{131}$,

A importância do tema da despesa pública, em pauta frequentemente, na análise dos doutrinadores pátrios, dentre eles José Mauricio Conti, sintetiza a complexidade do tema:

\begin{abstract}
Gastar dinheiro público não é fácil, e nem deve ser. Submetidas a uma série de procedimentos e controles, com a louvável finalidade de evitar desvios e mau uso dos recursos públicos, a despesa pública é um ato complexo. Previsão legal no orçamento, licitações, empenho, cronogramas, liquidações, enfim, há um longo percurso até o desembolso ${ }^{132}$.
\end{abstract}

Considerando as proposições inicias aliada à complexidade do ato de gastar, tendo em vista que primeiro o Estado deve realizar o planejamento do gasto que decorre da política pública (necessidades públicas eleitas) e da fixação da origem dos recursos para essa despesa (política fiscal executada por arrecadação), depois efetivá-lo de modo a atender a política pública fixada de forma eficiente, o que pressupõe um plexo de métodos técnicos que utiliza outras ciências, exemplificativamente as ciências econômicas, administrativas e contábeis, para o controle do processo de gastar com o objetivo de atender a finalidade estabelecida na política pública.

A proposição anterior demonstra a necessidade de se ter uma administração pública preparada para operacionalizar o gasto público de forma segura, rápida e eficiente, pois a realização tardia do gasto efetivo pode até mesmo inviabilizar a finalidade para a qual seria destinado.

Historicamente, o gasto público fora tratado não como um instrumento de atendimento das necessidades públicas, conforme exposto por Jèze:

\footnotetext{
Durante muito tempo, o elemento satisfação de uma necessidade pública foi negligenciado. Bodin, em 1576, dizia que as despesas públicas eram sempre uma boa coisa, porque fazia circular o dinheiro. Sir William Petty, apontava uma reserva: 'com a condição de que o dinheiro seja gasto no país'. Luiz XIV acreditava que as despesas extravagantes a que ele se entregou - como as centenas de milhões gastos em Versailles - não apenas eram
}

\footnotetext{
${ }^{131}$ JÈZE, Gastón. Cours Élémentaire des Science des Finances. Paris: V. Giard \& E. Brière, 1909. p. 372. Livro II.

${ }^{132}$ CONTI, José Mauricio. Não falta dinheiro à administração pública, falta gestão. Matéria do Consultor Jurídico, 31/12/2012. Disponível em < http://www.conjur.com.br/2012-jul-31/contas-vista-nao-falta-dinheiroadministracao-publica-falta-gestao>. Acesso em 28/12/2013.
} 


\begin{abstract}
legítimas, como beneficiavam o povo. E Voltaire o aprovava, com o argumento de Bodin e de Petty: essas despesas fazem circular o dinheiro no país. Da mesma forma, Frederico II, da Prússia, declarou seriamente que as despesas de suas numerosas armas eram uma boa coisa; elas ativam, dizia ele, a circulação do dinheiro. Ele também se preocupava em distribuir suas tropas pelas diferentes partes do território, para que cada um se beneficiasse dessa circulação. Adam Smith e J. B. Say mostraram que não se devia confundir essas duas coisas: a restituição do dinheiro, implicada pela despesa, e a utilização da despesa. Toda despesa - qualquer que seja o objeto - leva a uma circulação de dinheiro; mas se a despesa é feita por um objeto inútil, há uma dilapidação da riqueza. $\mathrm{O}$ contribuinte paga seu dinheiro e não recebe nada em troca. A confusão, muito frequente, serviu, por sua vez, de desculpa para extravagâncias e desperdício de dinheiro público $(\text { grifos nossos) })^{133}$.
\end{abstract}

Mas em importante observação Jèze identifica a qualidade na eleição da destinação dos gastos públicos não que não apenas realiza o atendimento das necessidades públicas mas também induz comportamentos econômicos que necessariamente implicam o desenvolvimento econômico-social do ambiente social, vejamos:

\begin{abstract}
[...] pode-se dizer que as despesas públicas úteis enriquecem um país, mas as despesas inúteis o empobrecem. As despesas inúteis absorvem, com efeito, os capitais que talvez estivessem sendo dirigidos à indústria privada; elas influem, portanto, indiretamente, sobre as condições da produção econômica. Com efeito, o desperdício nas despesas públicas, notadamente com a elevação excessiva dos salários pagos ao pessoal do Estado, tem sua contrapartida sobre a indústria privada que fica, também, obrigada a aumentar os salários (grifos nossos) ${ }^{134}$.
\end{abstract}

A execução do gasto público, dada a sua complexidade, visto que além de exercer uma atividade finalística de atender ao mesmo tempo os desígnios da política pública, a política fiscal deve necessariamente atender aos desígnios de impacto econômico de modo a induzir o total e pleno desenvolvimento econômico do Estado e do particular, Baleeiro:

O Estado não pertence ao reino dos céus. Reflete a sua condição de instituição do homem, passível de todos os defeitos inseparáveis da falibilidade humana. [...] A observação dos fatos mostra que o Estado obedece a critérios políticos quando institui o processo de serviço público para satisfação de determinadas necessidades coletivas. O parlamento, ou o ditador, faz a escolha, quando expede aos funcionários a autorização para o gasto (grifos nossos) ${ }^{135}$.

A falibilidade humana no exercício da atividade financeira do Estado, tem custo, que nas brilhantes palavras e Edgar Allix “o imposto serve não só para pagar os serviços do

\footnotetext{
${ }^{133}$ JÈZE, Gastón. Cours Élémentaire des Science des Finances. Paris: V. Giard \& E. Brière, 1909. p. 374-375. Livro II.

${ }^{134}$ Idem, ibidem. p. 379.

${ }^{135}$ BALEEIRO, Aliomar. Uma introdução à ciência das finanças. $12^{\mathrm{a}}$ ed. Rio de Janeiro, Forense, 1978. p. 73 e 77.
} 
Estado, senão também seus erros"136, de modo que na eleição de planos, processo, execução e aferição de resultados é imperioso a aplicação do princípio da eficiência, posto que a ineficiência quer significar perda recursos financeiros, não fomento das atividades econômicas para o desenvolvimento pleno, e o mais importante o não atendimento dos direitos e garantias fundamentais do cidadão.

Isso conforme a brilhante lição de Jose Afonso da Silva:

Finanças funcionais públicas são aquelas que se orientam no sentido de influir sobre a conjuntura econômica e se preocupam em conseguir o equilíbrio da economia como um todo, isso pelo "ajustamento dos fluxos de receitas e de despesas públicas em função das flutuações da atividade privada e em vista da obtenção de certo nível de renda e do emprego" 137 , e com isso, obter resultados positivos sobre a economia nacional $^{138}$. (grifos do autor)

O modelo de orçamento clássico como peça de previsão de receitas e autorização de despesas , a atividade financeira com intuito de obter resultados eficientes no atendimento das necessidades públicas e dentre elas o "impacto econômico positivo sobre a economia nacional" ${ }^{\text {139 }}$ era insuficiente , como demonstra Jose Afonso da Silva:

O orçamento clássico era uma peça de previsão de receitas e autorização de despesas públicas, classificadas essas por objeto, não era levado em consideração as necessidades reais da administração e da população, nem a perseguição de objetivos econômicos-sociais a atingir com sua execução. Informado pelos princípios do liberalismo, refletia a ideia de que a atividade financeira do Estado deveria restringir-se ao indispensável, à satisfação das necessidades primárias do Estado, vedada qualquer ingerência na ordem econômica e social" ${ }^{140}$. A neutralidade tornou-se insuficiente frente ao Estado Intervencionista, e nunca fora considerado o orçamento com um instrumento de ação direta sobre a economia ${ }^{141}$, era tão somente

\footnotetext{
136 ALLIX, Edgar. Traité Élementaire de Sciences des Fianances et de Legislação Financiere Francaise $.6^{\mathrm{a}}$ ed. Paris, 1931, p. 450. In Uma introdução à ciência das finanças. 12 $2^{\mathrm{a}}$ ed. Rio de Janeiro, Forense, 1978. p.06. ${ }^{137}$ BROCHIER-TRABATONI. Economie Financiere. pp.508-509. In SILVA, José Afonso da. Orçamento Programa no Brasil. São Paulo: Revista dos Tribunais, 1973. p. 05.

${ }^{138}$ SILVA, José Afonso da. Orçamento Programa no Brasil. São Paulo: Revista dos Tribunais, 1973. pp. $04-$ 05

${ }^{139}$ Idem, ibidem

${ }^{140}$ SILVA, José Afonso da. Orçamento Programa no Brasil. São Paulo: Revista dos Tribunais, 1973. pp. 0102.

${ }^{141}$ FONROUGE, Carlos M. Giuliani. Derecho Financeiro. $2^{\mathrm{a}}$ ed. Buenos Aires: Ediciones Depalma, 1970. p. 125. v. 1. In SILVA, José Afonso da. Orçamento Programa no Brasil. São Paulo: Revista dos Tribunais, 1973. pp. 02-03.
} 
um mero instrumento político e jurídico de previsões e de autorizações bem como um meio de controle Parlamentar sobre o Poder Executivo ${ }^{142}$.

Modernamente, o orçamento assumiu o caráter de uma ferramenta gerencial para a administração pública efetivar o gasto público, que possui evidente impacto macroeconômico, razão pela qual ao orçamento integra-se o planejamento (programa), porque traduz prioridades e estratégias de alcance de objetivos em ações que demandam dinheiro para serem concretizadas, vejamos:

O orçamento programa é uma modalidade especial de orçamento no qual a previsão dos recursos financeiros necessários, assim como sua destinação, decorre do estabelecimento prévio e completo de um plano. O orçamento programa é, pois componente do plano ${ }^{143}$.

A Constituição Brasileira de 1988 estabelece, no artigo 165, três instrumentos, orçamentários: o Plano Plurianual (PPA), a Lei de Diretrizes Orçamentárias (LDO) e a Lei Orçamentária Anual (LOA), cada qual com sua composição e finalidade, mas integrados entre si. Já no artigo 166, é fixado em detalhes um trâmite próprio do projeto de lei orçamentária, cuja iniciativa cabe ao poder Executivo e discussão, alteração e aprovação ao Legislativo. Por fim, no artigo 167 estão dispostos limites e vedações e no artigo 169, medidas para contenção com despesas de pessoal.

A adoção da sistemática do orçamento programa pressupõe racionalidade no manejo desses instrumentos, vejamos:

O sistema integrado planejamento-orçamento-programa, enquanto aplicado as decisões para efetuar despesas públicas, requer rigorosa e explicita definição de objetivos, ampla consideração de alternativas, sensível análise dos benefícios e dos custos de cada alternativa e, finalmente , o uso de análise no processo decisório ${ }^{144}$.

O Plano Plurianual (PPA), a Lei de Diretrizes Orçamentárias (LDO) e a Lei Orçamentária Anual (LOA) possuem precipuamente os objetivos de:

\footnotetext{
${ }^{142}$ COSCIANI, Cesare. Istituzioni di Scienza delle Finanze. $4^{\mathrm{a}}$ ed. Turim: Unione Tipografico-Editrice Torinese. pp. 680-681. In SILVA, José Afonso da. Orçamento Programa no Brasil. São Paulo: Revista dos Tribunais, 1973. p. 03.

${ }^{143}$ SILVA, José Afonso da. Orçamento Programa no Brasil. São Paulo: Revista dos Tribunais, 1973. p. 89.

${ }^{144}$ HAVERMAN, Robert Henry. The Economics of the Public Sector.página 169.In SILVA, José Afonso da. Orçamento Programa no Brasil. São Paulo: Revista dos Tribunais, 1973. p. 87.
} 


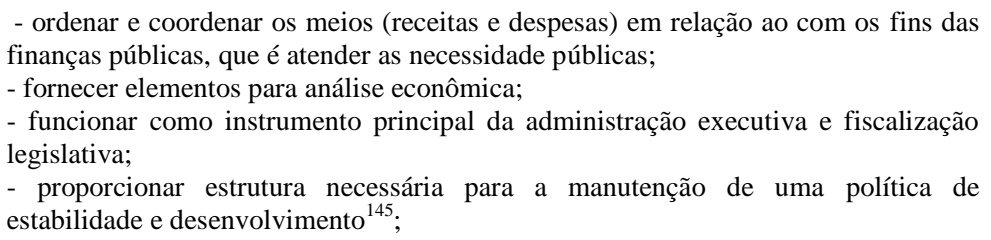

O princípio da eficiência pressupõe a análise do orçamento na justa medida de identificar se as necessidades públicas são atendidas de forma eficiente, identificar se a arrecadação fora eficiente, bem como se o gasto também o fora, nesse ponto importante ressaltar que isso implica no conhecimento específico da ordem jurídica, dos conceitos das ciências de administração, econômicas, estatísticas e quantas mais sejam utilizadas como auxiliares para identificar se os fins pretendidos foram alcançados de forma eficiente, a aferição ocorre conforme o estado atual da técnica (resultado eficiente possível aferido com base em método científico).

O princípio da eficiência resta atendido no exercício da atividade financeira do gasto público quando essa tem sucesso em realizar a atividade com a) igualdade ( cujo corolário é o princípio da capacidade receptiva; $b$ ) efetivo atendimento das as necessidades públicas e os direitos e garantias fundamentais do cidadão, efetividade subsumida à analise de desempenho, atendendo o mínimo existencial, limitado pela reserva do possível, por intermédio de instrumentos normativos racionais e eficientes ${ }^{146}$ (respeitando o limite do estado atual da técnica) para realizar eficiente utilização dos recursos públicos;

Isso porque do ponto de vista da eficácia (i) planejar e estabelecer metas a serem alcançadas pela tributação, e o (ii) agir concretamente para o alcance dessas metas de uma política pública necessariamente impende em (iii) aferir racionalmente a relação entre as metas alcançadas e a metas pretendidas, isso por avaliação de desempenho ou performance do gasto, posto que o que gastar, de acordo com os ditames constitucionais não é um fim em si mesmo.

A dimensão da efetividade impõe a análise do impacto sociais e econômicos da atividade de dispêndio financeiro, sem o qual não há como falar em gasto eficiente sob o

\footnotetext{
145 SILVA, José Afonso da. Orçamento Programa no Brasil. São Paulo: Revista dos Tribunais, 1973. p. 40.

146 Instrumentos normativos eficientes na atividade financeira : a instituição dos tributos, elaboração de políticas fiscais e públicas, no âmbito da concretude devem ser eficientes na efetivação do processo de tributar (instituição e cobrança) e de gastar os recursos públicos.
} 
aspecto do resultado, também é necessária a aferição da entender se uma despesa é eficiente do ponto de vista da eficiência-economicidade considerando a (i) o custo para atendimento de uma política versus objetivos pretendidos versus recursos disponíveis.

Assim concluímos que o interesse primário de atender as necessidades públicas com a efetivação do gasto público, perseguindo o bem-estar comum, inclui a necessidade pública que possui o cidadão de ter o gasto público realizado de forma eficiente na dimensão eficácia, efetividade e eficiência.

5.1. O custo dos direitos, a capacidade receptiva, a reserva do possível, o mínimo existencial e o princípio da eficiência

A proteção dos direitos fundamentais não deve impor apenas a um sujeito de direito a fruição de todos os direitos fundamentais em detrimento aos demais sujeitos, isso seria contrário a todo o primado da igualdade, portanto há que haver um juízo de ponderação que buscamos avaliar nesse ponto.

A proporcionalidade afigura-se como princípio hermenêutico conformador dos princípios constitucionais conflitantes, sempre se voltando para uma solução em que se verifique a adequação entre os meios e os fins constitucionais.

A proporcionalidade possui estrutura tríplice, sendo composta pelos subprincípios: (i) adequação, (ii) necessidade e (iii) proporcionalidade em sentido estrito. Assim, na análise da adequação, investiga-se se o meio utilizado pelo Estado para atingir determinado objetivo afigura-se idôneo. Questiona-se: é possível atingir tal fim pelo meio eleito? No que tange à necessidade, esta é analisada através da procura de outros meios menos restritivos do que o eleito pelo legislador, mas igualmente dotado de capacidade de atender ao fim almejado. Por fim, a proporcionalidade em sentido estrito implica na ponderação acerca das vantagens e desvantagens de efetivar tal medida idônea e necessária a atingir um fim público, mas que restringe um direito individual do particular.

Em suma, num Estado Democrático de Direito, que tutela os mais diversos interesses, a proporcionalidade passou a impor soluções jurídicas que conferissem a máxima efetividade aos princípios que colidem concretamente, consubstanciando sempre um juízo de adequação, 
necessidade e conformidade entre uma medida que impõe uma restrição a um bem juridicamente protegido e o peso que esta assume no caso concreto.

Nesse diapasão é que se analisa a possibilidade jurídica, aplicando-se o princípio da proporcionalidade, de se negar a concessão de direitos fundamentais prestacionais sob o fundamento da reserva do possível, que em síntese configura-se na possibilidade da mitigação da atuação estatal condicionando a prestação do Estado à existência de recursos públicos disponíveis.

A atuação do Poder Judiciário deve ser conforme a Constituição Federal, a previsão de prioridades em atender os direitos fundamentais de primeira e segunda geração deve ser respeitada, essa prescrição normativa é verdadeiro axioma para elaboração dos conteúdos de programas do governo (PPA- LDO - LO), ainda em relação à realização das despesas públicas, é cogente a aplicação do princípio da eficiência.

Nesse sentido, a simples afirmação de inexistência de recursos, destituída de conteúdo probatório (peça orçamentária e julgamento das contas do ente político) não é por si só argumento suficiente a motivar a negativa pelo Poder Judiciário da concessão de direitos prestacionais.

Ainda, ao se analisar os referidos elementos probatórios e se identificar que a realização das despesas não respeitou o plexo normativo constitucional e os princípios do Direito Financeiro, como por exemplo, e observar-se a realização de despesas supérfluas em detrimento a despesas essenciais que serviram ao atendimento de direitos e garantias fundamentais, também não há que se aceitar o argumento da inexistência de recursos, pois, em verdade, houve escolhas de prioridades diferentes daquelas determinadas pelo regime jurídico ao qual se deve estar adstrito.

No entanto a fruição dos direitos fundamentais de primeira e segunda geração, encontram-se limitados pela ponderação que pode ser feita pelo Poder Executivo e Poder Judiciário, em cada caso concreto se a concessão daquele direito demandado individualmente ou coletivamente, implicará na impossibilidade da manutenção da fruição dos direitos e garantias fundamentais da coletividade, pois ao Estado cabe zelar pelo atendimento das necessidades de toda a coletividade, sob pena de se ferir o princípio da igualdade, corolário de nosso sistema. 
5.2. A igualdade democrática e o princípio da diferença

As proposições assentadas permitem inferir que se chega à igualdade democrática, por meio da combinação do princípio da igualdade equitativa de oportunidades com o princípio da diferença. Em que as expectativas mais elevadas dos que estão em melhor situação serão justas se, e somente se, fizerem parte de um esquema que eleve as expectativas dos demais.

O princípio da liberdade expressa uma garantia da livre manifestação, o direito de votar e ser votado, o direito à vida, o mínimo existencial, enfim, todos os direitos individuais. "Cada pessoa deve ter direito igual ao mais abrangente sistema de liberdades básicas iguais que seja compatível com um sistema semelhante de liberdades para as outras".

O princípio da diferença está vinculado à idéia de igualdade, estabelece o pressuposto para legitimar as diferenças sociais e econômicas, desdobrando-se em dois subprincípios: (a) igualdade equitativa de oportunidades (assegura a todos acesso às posições sociais de destaque) e (b) princípio da diferença (as distinções entre pessoas só se justificam se trazem benefícios para toda a sociedade - o socialismo real mostra que a igualdade absoluta leva à estagnação e ao desestímulo). "As desigualdades sociais e econômicas devem ser ordenadas de tal modo que sejam ao mesmo tempo: (a) consideradas como vantajosas para todos dentro dos limites do razoável; (b) vinculadas a posições e cargos acessíveis para todos”.

Não faz diferença nenhuma na aplicação do princípio da diferença o grau de bem-estar que se desfrute dessa situação. Simplesmente elevamos ao máximo as expectativas da posição menos favorecidas obedecendo às restrições necessárias. Contanto que isso traga melhorias para todos, isso nos leva a crer que a melhoria geral das condições de vida e dignidade são obtidas com a vigência de um Estado Social.

Embora reconheça a importância, o autor não trata da qualidade da democracia, ou seja, que os cidadão conheçam e discirnam as características, planos de governos, objetivos dos representantes eleitos de forma a que os tenham eleito de maneira consciente, embora sejam essas questões que definam quais serão as prioridades no gasto público, isso em razão da proposta teórica retirar muitas variáveis para possibilitar a criação da teoria da justiça.

A expectativa adequada na aplicação do princípio da diferença é que as perspectivas, a longo prazo, dos menos favorecidos se estendam às gerações futuras. 
Cada geração deve preservar os ganhos em cultura e civilização e manter intactas as instituições justas que foram estabelecidas, também poupar a cada período de tempo um montante adequado de capital real.

Para que todas as gerações ganhem, as partes devem concordar com um princípio de poupança que assegure que cada geração receba de seus predecessores o que lhe é devido e faça a sua parte justa em favor daqueles que virão depois.

Uma sociedade cumpre seu dever de justiça ao manter instituições justas e preservar a sua base material e realizar as liberdades fundamentais.

O princípio da poupança restringe o princípio da diferença, quanto aplicado às gerações, pois embora os menos favorecidos devam ter suas expectativas maximizadas, eles devem respeitar a condição de fazer a poupança objeto do acordo. Embora o primeiro princípio de justiça e o princípio das oportunidades equitativas sejam anteriores ao princípio da diferença. Embora não haja necessidade de participação ativa dos menos favorecidos a participação consiste em darem aprovação aos arranjos econômicos e de outros tipos necessários à acumulação adequada.

A geração atual não pode fazer o que bem lhe aprouver, mas é obrigada, por princípios que seriam escolhidos na posição original, a definir a justiça entre pessoas que vivem em épocas diferentes.

5.3. Intersecção entre os pontos cruciais da teoria da justiça de John Rawls e o Gasto Público

A identificação do regime jurídico ao qual se submete o Direito Financeiro necessita da identificação dos princípios que regem esse arcabouço normativo, para tanto é esclarecedora a lição clássica do ilustre Prof. Geraldo de Camargo Vidigal, em sua obra Fundamentos do Direito Financeiro, que classifica os princípios gerais do Direito Financeiro em: a) Condicionais; b) Princípios técnicos; c) Princípio Final e esclaresce:

(...) chamam-se 'finais' aqueles princípios que iluminam as metas dos atos financeiros, orientando a regulamentação dos instrumentos de troca e sua utilização pelo Estado a partir da consideração dos objetivos perseguidos. 'Condicionais' são os princípios que ditam formas e processos indispensáveis à melhor utilização dos instrumentos de troca pelo Estado, em função de limitações que lhe impõem estruturas e conjunturas econômico-político-administrativas Por fim, denomina-se 'técnicos' os princípios que indicam extensão e limites do uso público dos 
instrumentos de troca, a partir de definição de mecanismos de repercussão desse uso no universo social ${ }^{147}$. (grifos do autor)

O princípio da eficiência não restará atendido se houver despesa supérflua em detrimento a despesa essencial, na dimensão da equanimidade. O princípio se concretiza pela obediência a economicidade e pela real satisfação dos interesses da Carta Magna e legislação infraconstitucional.

O Princípio da Eficiência pressupõe a escolha racional do gasto, e, embora esteja dentro do âmbito da decisão política, jamais poderá estar em descompasso com as prioridades definidas pela Constituição Federal, leis esparsas e as consolidações nas leis orçamentárias, nesse sentido resta importante relembrar as palavras do ilustre Prof. Celso Bastos, em que afirma: "o agente há que ter a melhor escolha; discricionariedade é a escolha da providência ótima”.

Nesse sentido, podemos indicar exemplos de prioridades definidas pela Constituição atual, como a fixação do gasto com a educação (art.212CF/88) e a inclusão pela Emenda Constitucional nº 29/2000 da saúde como prioridade ( $\$ 2^{\circ}$ do artigo $198 \mathrm{CF} / 88$ ).

5.4. O princípio da diferença e a parcela distributiva aos desiguais, proposta para uma análise da capacidade receptiva de recursos públicos

A leitura da obra de J. Rawls permite inferirmos que a despesa pública funciona como um elemento corretor de desigualdade, ou melhor, nivelador de condições sócio-economicas, em que se extrai que os menos afortunados pelas condições de nascimento independente de seus méritos ou esforços tem prioridade no acesso aos recursos públicos.

A fonte de recursos para o financiamento da atividade Estatal, em sua parcela mais significativa, advém de receitas derivadas,ou seja, a tributação da atividade do particular, que detenha expressão econômica.

O sistema jurídico tributário brasileiro subsumisse ao princípio da capacidade contributiva expresso no artigo $145 \S 1^{\circ}$ que determina que sempre que possível, os impostos terão caráter pessoal e serão graduados segundo a capacidade econômica do contribuinte, em

147 VIDIGAL, Geraldo de Camargo.Fundamentos do direito financeiro. São Paulo : Revista dos Tribunais, 1973. p. 95-98. 
que se infere que aquele que detém a maior capacidade econômica deve contribuir mais para a manutenção dos serviços públicos.

Diametralmente oposto é o princípio da capacidade receptiva no qual aqueles que detêm menos recursos, portanto menor capacidade econômica, devem ser beneficiados com uma gama de serviços públicos que os mantenham em condições dignas de vida e fruição dos direitos fundamentais albergados pela Constituição Federal.

Importante investigar quais seriam os efeitos práticos dessas proposições, posto que do ponto de vista da ciência ou da teoria, pode ser suficiente trazer o comentário de Erman MCMULLIN:

\begin{abstract}
Dizer que uma teoria simplesmente 'salva o fenômeno', apesar de carregar algum peso epistêmico, deixa aberta a suspeita de isto ser ad hoc. Se uma teoria for pensada simplesmente como um instrumento hipotético-dedutivo, seria plausível supor que outros instrumentos podem atuar bem ou melhor na explicação do fenômeno. Só quando uma dimensão temporal for acrescida, quando uma teoria for avaliada num contexto histórico, quando o seu sucesso na unificação de domínios através do tempo ou na previsão de novas espécies de fenômenos for levado em consideração é que aquela convicção começa a emergir. Teorias não são acessíveis apenas como predição; elas não são confirmadas somente pela enumeração de conseqüências $^{148}$. (grifo do autor)
\end{abstract}

A investigação se justifica em razão do fato de que em relação ao gasto público vige o princípio da eficiência e nessa esteira o resultado obtido deve necessariamente ser aferido.

No entanto, um momento antes dessa análise prática devemos ter em mente a assertiva de Zygmunt Bauman ${ }^{149}$ :

Não é apenas que a vida digna e o respeito devido à humanidade de cada ser humano
se combinem num valor supremo que não pode ser superado ou compensado por
nenhum volume ou quantidade de outros valores, mas que todos os outros valores só
são valores na medida em que sirvam à dignidade humana e promovam a sua
causa.Todas as coisas valorosas na vida humana nada mais são que diferentes fichas
para aquisição do único valor que torna a vida digna de ser vivida.Aquele que busca
a sobrevivência assassinando a humanidade de outros seres humanos sobrevive à
morte de sua própria humanidade. A negação da dignidade humana deprecia o valor

148 "To say that a theory simply 'saves the phenomena' though this caries some epistemic weight, leaves open the suspicion of its beeing ad hoc. If a theory be thought of simply as an hypothetico-dedutive device, it would seem plausible to suppose that other devices might account as well or better for the phenomena to be explained. It is only when temporal dimension is added, when a theory is evaluated in a historical context, when its success in unifying domains over time or predicting new sorts of phenomena are taken into account, that conviction begins to emerge. Theories are not assessed simply as predictors; they are not confirmed only by the enumeration of consequences". (MCMULLIN, Erman. Racionality and paradigm change. In: CURD, Martin, COVER, J.. A. Philosophy of science. NewW. W. Norton,1998,. p. 135)

${ }_{149}$ BAUMAN, Zigmunt. Amor líquido. Rio de Janeiro: Zahar, 2011. pp. 102-103. 
de qualquer causa que necessite dessa negação para afirmar a si mesma.E o sofrimento de uma única criança deprecia esse valor de forma tão radical e completa quanto o sofrimento de milhões. (grifos do autor)

Nesse contexto sociológico temos que o valor dignidade humana esta albergado em valores constitucionais que oferecem ao leitor a possibilidade de construção de direitos mínimos existenciais que são considerados indispensáveis à manutenção da dignidade humana.

Regina Helena Costa em sua obra Praticabilidade e Justiça Tributária ${ }^{150}$ cita Joseph Isensee: “ o destino do imposto esta ligado à igualdade", posto que aponta o princípio da capacidade contributiva como critério ético da imposição tributária, porquanto responde aos reclamos da justiça tributária,voltada à minimização das disparidades sociais e econômicas.

O primado da capacidade contributiva é a aptidão de caráter econômico de o cidadão concorrer aos gastos públicos de forma isonômica aos demais, a proposta de J. Rawls ao estabelecer o princípio da diferença é estabelecer o fator discriminador da igualdade no campo da justiça social, de modo a prover a esses sujeitos de direitos a prioridade na percepção de recursos públicos.

O Estado Social é um estado custoso, pois as prestações positivas envolvem maior dispêndio de recursos, no entanto, observando alguns trabalhos e resultados da aplicação desses recursos públicos se verifica que a utilização dos recursos públicos se justifica na medida em que previne o nascimento de diversos problemas sócio-economico, sobre esse aspecto vejamos Tony $\mathrm{Judt}^{151}$ :

A desigualdade, portanto, não e desestimulante por si só: ela conduz a problemas sociais patológicas que só podemos resolver se lidarmos com sua causa subjacente. Existe um motivo para mortalidade infantil, expectativa de vida, criminalidade, população carcerária, doença mental,desemprego,obesidade,subnutrição,gravidez na adolescência,uso de drogas ilegais,insegurança econômica,endividamento pessoal e ansiedades serem muito marcantes nos EUA e na Grã-Bretanha do que na Europa continental.Quanto maior a distância entre os poucos ricos e os numerosos pobres, piores os problemas sociais: o conceito se aplica tanto aos países ricos quanto aos países pobres, piores os problemas sociais: o conceito se aplica tanto aos países ricos quanto aos pobres.Não importa o quanto uma nação seja afluente,mas sim seu grau de desigualdade.A Suécia ou a Finlândia,dois dos países mais ricos do mundo em renda per capita e PIB, apresentam uma distância pequena entre os cidadãos

\footnotetext{
${ }^{150}$ COSTA, Regina Helena. Praticabilidade e Justiça Tributária. São Paulo: Malheiros, 2007. p. 113.

151 JUDT, Tony. O mal ronda a Terra. São Paulo: Objetiva, 2011. p. 29.
} 
mais ricos e o mais pobres - e portanto lideram de forma consistente os índices mundiais de bem estar mensurável ${ }^{152}$.

Amartya Sem em sua obra Desenvolvimento como liberdade faz uma análise interessante de como os países em desenvolvimento, dito pobres, possuem uma vantagem em relação ao custo de salários para a remuneração de trabalhos em áreas como saúde e educação, consideradas indispensáveis ao progresso e desenvolvimento econômico, que nem de longe se comparam aos custos que países desenvolvidos precisam dispender para prestar os mesmos serviços ${ }^{153}$, ou seja, a possibilidade de superação dos obstáculos é real.

Compartilhamos da ideia exposta por Michel de Foucault:

\begin{abstract}
Ainda nos poetas gregos do sec.VI, o discurso verdadeiro - no sentido forte e valorizado do termo - pelo qual se tinha respeito e terror, aquele ao qual era preciso submeter-se, porque ele reinava, era o discurso pronunciado por quem de direito e conforme o ritual requerido; era o discurso que pronunciava a justiça e atribuía a cada qual sua parte; era o discurso que,profetizando o futuro, não somente anunciava o que ia se passar,mas contribuía para a sua realização, suscitava a adesão dos homens e se tramava assim com o destino.Ora eis que um século mais tarde, a verdade já não residia nas no que era o discurso, ou no que ele fazia, mas residia no que ele dizia: chegou um dia em que a verdade se deslocou do ato ritualizado,eficaz e justo, de enunciação, para o próprio enunciado: para seu sentido, sua forma, seu objeto, sua relação a sua referência. Entre Hesíodo e Platão uma certa divisão se estabeleceu, separando o discurso verdadeiro e o discurso falso; separação nova visto que, doravante, o discurso verdadeiro não é mais o discurso precioso e desejável,visto que não é mais o discurso ligado ao exercício do poder. O sofista é enxotado.Essa divisão histórica deu sem dúvida sua forma geral à nossa vontade de saber.Mas não cessou, contudo de deslocar: as grandes mutações científicas podem talvez ser lidas, às vezes,como conseqüências de uma descoberta, mas podem também ser lidas como a aparição de novas formas na vontade da verdade.Há sem dúvida, uma vontade de verdade no século XIX, que não coincide nem pelas formas que põe em jogo,nem pelos domínios de objeto aos quais se apóia, com a vontade de saber que caracteriza a cultura clássica. (grifos do autor)
\end{abstract}

Isso porque entendemos que a Constituição Federal albergou o princípio da diferença pela via da capacidade receptiva ${ }^{154}$ que busca bases solidas no princípio da capacidade contributiva, ainda que os direitos fundamentais à manutenção de uma vida digna, já tratados em outro momento, estão perfeitamente delimitados e sua fruição deve ser imediata.

\footnotetext{
${ }^{152}$ Nota: A melhor defesa desses argumentos consta na obra Richard Wilkinson e Kate Pickett.The spirit level Why More Equal Societies Almost Always do Better (O nível do espírito: porque sociedades menos desiguais quase sempre têm um melhor desempenho. Londres: Allen Lane,2009).

${ }^{153}$ SEN, Amartya. Desenvolvimento como liberdade. Local: Companhia de Bolso, 2010. p. 70.

${ }^{154}$ OLIVEIRA, Regis Fernandes de. Curso de direito financeiro. $3^{\mathrm{a}}$ ed. rev.e atualizada. São Paulo: Editora Revista dos Tribunais, 2010. p. 299.
} 
Isso porque a verdade está contida nos instrumentos normativos vigentes que fixam os direitos substantivos, os aspectos formais (processuais) se encontram de forma exaustiva na legislação procedimental e também nos instrumentos normativos produzidos à exaustão, ainda existe a previsão das punições em relação ao não atendimento às normas substantivas e procedimentais, que sofrem a aferição por tribunais administrativos especializados, sob a espada da Lei de Responsabilidade Fiscal.

O problema da aplicação dos recursos públicos reside nos aspectos intrínsecos à natureza humana, e na busca da satisfação dos desejos pessoais, dentre eles a manutenção de poder e o acúmulo de riquezas, sem se importarem com o destino dos demais.

A justiça na instituição deveria inibir essa prática pela aplicação da sanção adequada, mas padece do mesmo mal, o capital adquiriu a importância e relevância tamanha que o PIB é medido considerando a quantia de dispêndio econômico, ou seja, consumo, o consumidor e a manutenção do consumo é crucial, nesse passo o homem adquire uma posição secundária.

O biopoder, a política para manutenção da vida, é a manifestação primeira de que atualmente estamos no caminho equivocado, pois hoje vivemos sob a égide da política para a manutenção de mercados de consumo não para manutenção das pessoas em condições dignas de vida, sob esse aspecto ideológico entendemos não ser eficiente o marco teórico firmado que em algum momento desviou os objetivos a que serve os recursos financeiros daqueles que estabelecem a valorização da vida, resgatado no biopoder por Michel de Foucault. 


\section{O PRINCÍPIO DA EFICIÊNCIA E A TRANSPARÊNCIA FISCAL NO EXERCÍCIO DA ATIVIDADE FINANCEIRA DO ESTADO}

O acesso à informação é um direito indiscutível que ganhou maior grau de concretude em relação à atividade financeira do Estado depois da aprovação da Emenda Constitucional $\mathrm{n}^{\circ}$ 19 de 1998, que alterou o caput do artigo 37 da Constituição Federal de 1988, isso porque na dimensão da efetividade, que exige atividade de comparação, para aferição de resultados, a informação é pressuposto. Não se compara aquilo que não se conhece.

O acesso à informação configura verdadeiro comando constitucional, é possível identificar o comando normativo da informação em diversos trechos da Constituição da República de 1988, entre outros, no art. 5, incisos XIV (acesso à informação), XXXIII, XXXIV, alínea 'a' (direito de petição), LXXII (habeas data) e LXXIII (ação popular); art. 70 (controle externo e interno e dever de prestar contas); art.165, $\$ 3^{\circ}$ (relatório resumido de execução orçamentária). Cumpre mencionar que o Brasil é signatário de Convenções Internacionais, entre elas a que teve lugar na Assembleia-Geral da ONU, em 31 de outubro de 2003, (Art. 10 da Convenção das Nações Unidas contra a Corrupção) e a Declaração Universal dos Direitos Humanos que estabeleceu em seu art. Art. XIX, verbis: toda pessoa tem "direito à liberdade de opinião e expressão; este direito inclui a liberdade de, sem interferência, ter opiniões e de procurar, receber e transmitir informações e ideias por quaisquer meios e independentemente de fronteiras. (Grifos nossos).

A transparência fiscal, foi veiculada pelos artigos 48, 48-A e 49 da Lei Complementar $\mathrm{n}^{\circ}$. 101, de 4 de maio de 2000 (atualizada pela Lei Complementar $\mathrm{n}^{\circ} .131$, de 27 de maio de 2009). O artigo 48 é regulamentado pelo Decreto nº 7.185 do Presidente da República, de 27 de maio de 2010 e pela Portaria ${ }^{\circ} .548$ do Ministro da Fazenda, de 22 de novembro de 2010.

O advento da Lei Complementar $\mathrm{n}^{\circ} 131 / 09$ acrescentou dispositivos à Lei Complementar $n^{\circ} 101 / 00$, a fim de fomentar a disponibilização, em tempo real, de informações detalhadas acerca da execução orçamentária e financeira da União, dos Estados, do Distrito Federal e dos Municípios.

O parágrafo único do art. 48 da $\mathrm{LC}^{\circ}{ }^{\circ} 101 / 00$ estabelece que a transparência também seja assegurada mediante a adoção de sistema integrado de administração financeira e controle que atenda ao padrão mínimo de qualidade estabelecido pelo Poder Executivo da União. 
O Decreto $N^{o} 7.185$, de 27 de maio de 2010, dispõe sobre o padrão mínimo de qualidade do sistema integrado de administração financeira e controle, no âmbito de cada ente da Federação, especificamente o artigo $2^{\circ}, \S 2^{\circ}$ inciso I, dispõe que tal sistema deverá ser integrado, o que nos permite inferir que o é com os respectivos Portais de Transparência de forma que sejam disponibilizadas para a sociedade, no mínimo, as informações orçamentárias e financeiras exigidas pela lei, verbis:

Art. $2^{\underline{0}}$ O sistema integrado de administração financeira e controle utilizado no
âmbito de cada ente da Federação, doravante denominado SISTEMA, deverá
permitir a liberação em tempo real das informações pormenorizadas sobre a
execução orçamentária e financeira das unidades gestoras, referentes à receita e à
despesa, com a abertura mínima estabelecida neste Decreto, bem como o registro
contábil tempestivo dos atos e fatos que afetam ou possam afetar o patrimônio da
entidade.
$\S 1^{\underline{0}}$ Integrarão o SISTEMA todas as entidades da administração direta, as
autarquias, as fundações, os fundos e as empresas estatais dependentes, sem prejuízo
da autonomia do ordenador de despesa para a gestão dos créditos e recursos
autorizados na forma da legislação vigente e em conformidade com os limites de
empenho e o cronograma de desembolso estabelecido.
$\S 2^{\underline{0}}$ Para fins deste Decreto, entende-se por:
I - sistema integrado: as soluções de tecnologia da informação que, no todo ou em
parte, funcionando em conjunto, suportam a execução orçamentária, financeira e
contábil do ente da Federação, bem como a geração dos relatórios e demonstrativos
previstos na legislação (

Os principais sistemas governamentais são o Sistema Integrado de Administração Financeira do Governo Federal (SIAFI), o Sistema Integrado de Administração Financeira dos Estados e Municípios (SIAFEM), o Sistema PREFEITURA LIVRE e o Sistema ECIDADE. O padrão mínimo de qualidade do sistema integrado de administração financeira e controle é regulamentado da seguinte forma:

[...]Art. 4o [...] consistem requisitos tecnológicos do padrão mínimo de qualidade do sistema: I - disponibilizar ao cidadão informações de todos os Poderes e órgãos do ente da Federação de modo consolidado; II - permitir o armazenamento, a importação e a exportação de dados; e III - possuir mecanismos que possibilitem a integridade, confiabilidade e disponibilidade da informação registrada e exportada. Art. 50 o sistema atenderá, preferencialmente, aos padrões de arquitetura e-PING Padrões de Interoperabilidade de Governo Eletrônico [...].

Entendemos que a integração dos sistemas supra mencionados não seja tarefa das mais simples, e ainda que os padrões mínimos de qualidade exigidos não permite que a administração adote qualquer sistema desprovido de capacidade para viabilizar a transparência da gestão fiscal. O sistema deve possuir elevado desempenho operacional para ser capaz de disponibilizar as informações exigidas nos respectivos Portais de Transparência. 
No entanto reside uma questão de falha com relação confiabilidade do sistema ${ }^{155}$, posto que não resta definido expressamente de quem será a competência para "certificar" se os sistemas utilizados estão "atendendo" ou "não" o padrão mínimo de qualidade exigido, entendemos se tratar medida de rigor que a responsabilidade por essa função.

Outro ponto a se destacar é que quanto às informações mínimas das despesas, que a Lei Complementar 101/2000 (Lei de Responsabilidade Fiscal) estabeleceu critérios de disposição e acessibilidade, verbis:

Art. 48-A [...] os entes da Federação disponibilizarão a qualquer pessoa física ou jurídica o acesso a informações referentes a: I - quanto à despesa: todos os atos praticados pelas unidades gestoras no decorrer da execução da despesa, no momento de sua realização, com a disponibilização mínima dos dados referentes ao número do correspondente processo, ao bem fornecido ou ao serviço prestado, à pessoa física ou jurídica beneficiária do pagamento e, quando for o caso, ao procedimento licitatório realizado.

A medida acima impõe um padrão de qualidade na informação sobre a execução do gasto público, o que possibilita o melhor controle entre as finalidades pretendidas pela politicas públicas e finalidades efetivamente alcançadas em razão da conferência da execução de despesas públicas. Nesse particular, entendemos tratar de um especial avanço para realização do princípio da eficiência, no entanto, em termos de coerção, temos que o não cumprimento do dever de transparência de informações impõe aos entes federativos apenas a impossibilidade de receber transferências voluntárias do Governo Federal.

Resta um dilema aparentemente insolúvel, nesse ponto, posto que embora quem descumpra o dever de transparência seja a administração pública, em verdade a penalidade recai sobre o administrado, posto que o ente federativo, terá a limitação no recebimento de recursos que, em última análise, significa falta de recursos para atender as necessidades públicas.

Cumpre mencionar que o Brasil solidário ao esforço global do Fundo Monetário Internacional - FMI para promover maior transparência no sistema financeiro internacional, de modo que divulga suas estatísticas de Finanças Públicas de acordo com o Padrão Especial para Divulgação de Dados (PEDD ou SDDS em inglês) criado em 1996, que tem como

\footnotetext{
${ }^{155}$ Nota do autor. Portaria ${ }^{\circ} 548 / 10$, estabelece requisitos mínimos de confiabilidade e de segurança do sistema integrado de administração financeira e controle, adicionais aos previstos no Decreto $\mathrm{n}^{\circ} 7.185 / 10$.
} 
objetivo fornecer e disseminar ao público informações econômicas e financeiras possibilitando a comparação entre países, que se configura como um elemento fundamental, contribuindo para a elaboração de políticas macroeconômicas sólidas.

Em relação à transparência, devemos mencionar que também fora adotada a transparência fiscal nas relações entre particulares, em determinadas operações civis (compra e venda - consumidor final), com relação à matéria tributária. Isso em razão da edição da Lei $\mathrm{n}^{\mathrm{o}}$ 12.741, de 08 de dezembro de 2012 que dispõe sobre as medidas de esclarecimento ao consumidor exigindo que todo documento fiscal ou equivalente emitido contenha a informação do valor aproximado correspondente à totalidade dos tributos federais, estaduais e municipais, cuja incidência influi na formação dos respectivos preços de venda.

O descumprimento das normas relativas à divulgação dos tributos sujeitará o infrator às sanções previstas no Capítulo VII do Título I da Lei 8.078/1990 (Código de Defesa do Consumidor).

A apuração do valor dos tributos incidentes deverá ser feita em relação a cada mercadoria ou serviço, separadamente, inclusive nas hipóteses de regimes jurídicos tributários diferenciados dos respectivos fabricantes, varejistas e prestadores de serviços, quando couber).

As medidas adotadas, ainda que carentes de alguns reparos, demonstram o caminho perseguido pela vontade dos cidadãos brasileiros que é identificar a relação tributaçãodispêndio, com clareza de modo a compreender o seu papel na manutenção da coisa pública por meio do dever fundamental de pagar tributos.

Com relação à transparência, as informações devem ser claras e acessíveis. A transparência somente se aperfeiçoa quando ocorre a inteligibilidade dos dados ou das informações disponibilizadas, assim a informação disponibilizada como um fim em si, produzidas sem confiabilidade, qualidade de dados e de fontes, não atende aos princípios da eficiência em si mesma. 


\section{A QUESTÃo dA AFERIÇÃo CONCRETA dO RESPEITO AO PRINCÍPIO DE EFICIÊNCIA NA ATIVIDADE FINANCEIRA DO ESTADO}

O direito como ciência descritiva tem como dado material a lei que é o objeto de sua análise e descrição, no caso da atividade financeira do Estado, o corte gnosiológico realizado, determina a análise do sistema de normas que regem a atividade financeira do Estado. Essa metodologia implica uma questão primordial, se à atividade financeira é atribuído o dever de resultado eficiente, a análise desse resultado é um dado material do direito financeiro?

O direito financeiro deve eleger esse dado como objeto de estudo? A que ciência cabe a análise da correlação entre a atividade normativa do Estado em matéria financeira e os resultados obtidos dessa atividade financeira, julgando esses dados e prescrevendo correções para um agir mais eficiente.

É uma análise de desempenho do agir administrativo com base na correlação de prescrições normativas e números, acreditamos se tratar de uma nova perspectiva de análise baseada na inserção da eficiência como princípio constitucional.

Acreditamos que houve uma ampliação de objeto visto que não basta haver a norma financeira: ela deve ser eficiente em realizar os desígnios constitucionais impostos a essa atividade, de modo que cabe ao direito financeiro, como ciência descritiva, estudar essas correlações desde identificar a relação de pertinência e validade que a norma financeira exerce sobre o ordenamento jurídico financeiro, até a concretude manifesta pelos controles gerenciais da atividade de tributar e efetivar o gasto público, isso com auxílio das demais ciências (matemática, administração, contabilidade, economia, sociologia e quantas mais forem necessárias).

A Constituição Federal estabelece que o Poder Legislativo, o Poder Executivo e o Poder Judiciário, manterão de forma integrada, o controle interno e externo dos os atos da administração financeira e orçamentária, de modo que a prestação de contas de cada esfera de poder esta submetida ao controle do Congresso Nacional auxiliados pelo Tribunal de Contas da União.

As finalidades desse controle estão estabelecidas no artigo 74 da Constituição Federal e a forma de atuação varia, admitindo-se diversas maneiras de proceder, dentre as quais, a analise da prestação de contas, princípio fundamental da ordem constitucional ( artigo 34, VII, 
d da Constituição Federal), pela análise dos o registros contábeis e financeiros das movimentações de recursos, meio de registro hábil a viabilizar o exercício do controle.

O controle externo é função do Poder Legislativo, nos respectivos âmbitos, federais, estaduais e municipais com o auxílio dos respectivos Tribunais de Contas. Referido controle desempenha a função fiscalizadora, por representação democrática, dos atos da administração financeira e orçamentária, e essa característica lhe confere natureza política, o Tribunal de Contas, por sua vez, desempenha a função de órgão eminentemente técnico, o que quer significar que o controle externo há de ser primordialmente de natureza técnica ou numéricolegal, que prioriza a análise sob o ponto de vista da legalidade e regularidade de despesa.

O controle externo exercido pelo Congresso Nacional compreende a fiscalização contábil, financeira, orçamentária, operacional e patrimonial da União e das entidades da administração direta e indireta quanto a legalidade, legitimidade, economicidade, aplicação das subvenções e renúncia de receitas, sinteticamente, o controle externo incide sobre qualquer atividade que possa gerar resultados patrimoniais mensuráveis, positivos ou negativos.

Todos os Poderes da República Federativa do Brasil estão sujeitos à prestação e tomadas de contas pelo sistema interno, em primeiro lugar, e pelo sistema de controle externo. A atividade do julgamento da prestação de contas consiste em formação de juízo a posteri formulando juízo de conformação das contas à legalidade adstrita à realização dos registros contábeis financeiros ,e à legitimidade que implica em juízo de valor da "conexão funcional" da atividade de tributar e despender recursos financeiros e economicidade.

O princípio da eficiência confere nova formação ao juízo de legitimidade no julgamento das contas públicas, dada à positivação do comando que passa não mais ser aceitável a adoção de uma providencia administrativa que resulte em gastos públicos sem privilegiar o cumprimento dos direitos e garantias fundamentais.

Importante mencionar alguns instrumentos atuais, sem pretensão de esgotá-los, que representam importância elevada na aferição da atividade financeira do Estado:

- Lei $\mathrm{n}^{\circ}$ 10.180, de 6 de fevereiro de 2001, visa ao equilíbrio econômico-financeiro do Governo Federal, dentro dos limites da receita e despesa públicas, e compreende a atividade de programação financeira da União. Cabe à Secretaria do Tesouro Nacional o papel de órgão central do referido sistema. Tem por objetivo compatibilizar a realização da receita e a execução da despesa, observando-se as metas de resultado primário estabelecidas, fixando 
limites para a movimentação e empenho e para o pagamento das despesas dos grupos “outras despesas correntes", “investimento" e "inversões financeiras” dos órgãos do Poder Executivo e respectivos restos a pagar de exercícios anteriores. No decorrer do exercício, podem ocorrer revisões bimestrais das projeções de receitas e despesas, incorrendo em alterações no Decreto de Programação Financeira.

- Relatório de Cumprimento de Metas - Em relação à execução orçamentária, Lei de Responsabilidade Fiscal (LRF) (art. $9^{\circ}, \S 4^{\circ}$ ) estabelece que o Poder Executivo estabelecerá a programação financeira e o cronograma de execução mensal de desembolso no prazo de até 30 dias após a publicação da LOA. Objetivando o contínuo monitoramento da compatibilidade entre a execução orçamentária e financeira e a meta de superávit primário prevista na LDO;

- Relatório de avaliação das receitas e despesas primárias. - no âmbito do Governo Federal é publicado bimestralmente. Verificado, ao final de um bimestre, que a realização da receita poderá não comportar o cumprimento da meta (Relatório de Cumprimento de Metas), o Poder Executivo apura a necessidade de limitação de empenho e movimentação financeira da União, comunicando aos Poderes Legislativo e Judiciário e ao Ministério Público, que por ato próprio promovem a limitação segundo os critérios estabelecidos pela LDO. A avaliação do cumprimento das metas fiscais legitima os processos de planejamento e orçamento do governo, uma vez que permite aos agentes econômicos aferirem sobre o desempenho da administração pública face a sua responsabilidade com a sustentabilidade fiscal intertemporal.

Janete Duarte, em conjunto com outros autores, realizou um estudo para avaliar se os critérios técnicos de distribuição de recursos definidos pelo artigo 35 da Lei 8.080/1990 (critérios para estabelecer valores de transferência) são meios eficientes para promoção dos serviços de saúde de qualidade, relevante o estudo posto que os autores reconhecem que há "uma percepção quase generalizada de que o aumento dos recursos públicos para a saúde resolveria todos os problemas. Mas a reclamação por mais recursos só faz sentido se os recursos existentes estão sendo empregados de forma eficiente"156

O resultado do trabalho demonstra que:

(...) o gasto com saúde responde de maneira positiva a um aumento da demanda por consultas e exames. Além disso, observa-se que o aumento da eficiência da prestação

\footnotetext{
${ }^{156}$ DUARTE, Janete et al. Os determinantes da Eficiência dos Estados no Gasto Público de Saúde. Textos Para Discussão do Tesouro Nacional. Local: Editora, n 9, p. 06, 2012.
} 
de serviços de saúde está associada à cobertura dos serviços de saneamento, às características demográficas da população, ao nível de renda e à incidência de epidemias.

(...) As evidências empíricas obtidas nesse estudo indicam que os critérios elencados nos incisos I, II e VI do artigo 35 da Lei 8.800/1990 se confirmam como adequados para avaliar a importância dos fatores de distribuição na explicação da ineficiência.

O trabalho é inovador tendo em vista que, por critérios matemáticos, analisa as prescrições normativas em matéria financeira identificando se os critérios normativos são eficientes ao fim a que se destina, que é estabelecer os valores que a União irá transferir aos Estados, Distrito Federal e Munícipios.

A realização de um estudo dessa monta a cada enunciado prescritivo editado seria uma atividade impossível, e ineficiente, o que reconhecemos. No entanto, acreditamos que com parcimônia seria possível essa atividade de aferição para enunciados que versem sobre destinação de recursos públicos.

Cabe a necessidade de especialização técnica para à eleição do método de análise de desempenho e eleição das variáveis (indicadores), que sejam adequados, visto que devem expressar em seus dados confiabilidade.

O método mencionado é adequado para utilização em duas etapas (i) no planejamento das prescrições normativas a atividade financeira, na medida em que permite avaliar se os critérios estabelecidos para construção do enunciado legal são aptos a possibilitar o atingimento dos fins perseguidos, e em outro momento, (ii) na concreta aferição de desempenho dos critérios normativos para o atendimento de uma finalidade, visto que pode ser utilizado para avaliar se a despesa espelhada na peça orçamentária realiza os desígnios constitucionais.

A utilização do método depende da transformação dos enunciados legais em variáveis e necessita do conhecimento do jurista para que os ditames constitucionais sejam representados na ciência matemática de modo a respeitar os desígnios constitucionais, esse , seria ao nosso ver a máxima expressão do principio da eficiência no direito financeiro. 


\section{CONCLUSÃO}

1. A Jurisprudência dos valores rompe com o positivismo das correntes anteriores, tanto do positivismo normativista quanto do positivismo sociológico, e se inicia uma reaproximação entre o direito e a moral; entre o direito e a ética; o resgate do ideal de justiça e da teoria dos direitos fundamentais.

2. Rawls constrói um núcleo duro do conceito de justiça, que assevera que cada pessoa possui uma inviolabilidade fundada na justiça que nem o bem-estar de toda a sociedade pode desconsiderar. Os direitos e liberdades da cidadania igual são considerados irrevogáveis e devem ser garantidos pela justiça não estão sujeitos a negociações políticas.

3. A justiça de um arranjo social depende, em essência, de como se atribuem os direitos e os deveres fundamentais e também as oportunidades econômicas e das condições sociais dos diversos setores da sociedade.

4. As desigualdades sociais e econômicas, somente serão justas se resultarem em vantagens recompensadoras para todos e, em especial, para os membros menos favorecidos da sociedade. Ambas as afirmações funcionam como neutralizadores aos acidentes da dotação natural e das contingências das circunstâncias sociais.

5. O princípio da diferença está vinculado à ideia de igualdade, estabelece o pressuposto para legitimar as diferenças sociais e econômicas, desdobrando-se em dois subprincípios: (a) igualdade equitativa de e (b) princípio da diferença.

6. As proposições assentadas permitem inferir que se chega à igualdade democrática, por meio da combinação do princípio da igualdade equitativa de oportunidades com o princípio da diferença.

7. A dúvida sobre os elementos indispensáveis que compõem os direitos e garantias fundamentais para alocação de recursos públicos quer nos parecer uma falácia, dado que entendemos estar muito claro que o emprego dos recursos estão adstritos a regras rígidas de formais e substanciais.

8. A temática da $\mathrm{CF} / 88$ visa garantir a participação popular no processo político, estabelecer uma sociedade livre, justa e solidária, em que todo o poder emana do povo, diretamente ou por representantes eleitos, respeitando a pluralidade de ideais, culturas e etnias, isso para garantir os direitos fundamentais da pessoa humana e na mesma medida que prioriza, fornece os vetores para realização do gasto público. 
9. O Poder Executivo, além de ajustar seu plano político aos players políticos, teve que se preocupar em não infringir a Constituição por ação ou omissão. De maneira simplificada, essa é a síntese do cenário que assentou o sistema político (democracia) e seus novos guardiões (a Constituição e os juízes).

10. O Direito Financeiro deve se preocupar com o estudo da eficiência do gasto público, a dimensão humana (finalidade) e a realização da despesa para concretizar a redução de desigualdade (art. $3^{\circ}$, inciso II, CF) e dar esplendor a dignidade da Pessoa Humana (artigo $1^{\mathrm{a}}$ inciso II, CF), mesmo que para análise de desempenho precise se socorrer de outras ciências.

11. O Princípio da Eficiência trazido pela Emenda Constitucional nº19/98 que impõe a análise da adequação da despesa ao atingimento da finalidade a que se destina, mediante o estudo do custo- benefício da despesa e o atingimento do resultado, que necessariamente, deve ser aferível, portanto demonstrável.

12. Determina a impossibilidade da despesa supérflua em detrimento da despesa essencial, na dimensão da equanimidade. O princípio se concretiza pela obediência a efetividade, eficácia e eficiência-economicidade e pela real satisfação dos interesses da Carta Magna e legislação infraconstitucional.

13. O princípio da eficiência pressupõe a escolha racional do gasto e, embora esteja dentro do âmbito da decisão política, jamais poderá estar em descompasso com as prioridades definidas pela Constituição Federal, leis esparsas e as consolidações nas leis orçamentárias, nesse sentido Prof. Celso Bastos, em que afirma que "o agente há que ter a melhor escolha; discricionariedade é a escolha da providência ótima".

14. Prioridades definidas pela Constituição atual: a fixação do gasto com a educação (art.212CF/88) e a inclusão pela Emenda Constitucional nº 29/2000 da saúde como prioridade ( $\$ 2^{\circ}$ do artigo $\left.198 \mathrm{CF} / 88\right)$, direitos sociais, a Constituinte tutelou o direito à alimentação e à moradia.

15. O princípio da capacidade contributiva é critério ético da imposição tributária, porquanto responde aos reclamos da justiça tributária, voltada à minimização das disparidades sociais e econômicas.

16. A Constituição Federal albergou o princípio da diferença pela via da capacidade receptiva que busca bases sólidas nos direitos fundamentais à manutenção de uma 
vida digna, já tratados em outro momento, estejam perfeitamente delimitados e sua fruição deve ser imediata.

17. A verdade está contida nos instrumentos normativos financeiros vigentes que fixam os direitos substantivos. Os aspectos formais (processuais) estão presentes de forma exaustiva na legislação procedimental e nos instrumentos normativos, ainda existe a previsão das punições em relação ao não atendimento às normas substantivas e procedimentais, que sofrem a aferição por tribunais administrativos especializados, sob a espada da Lei de Responsabilidade Fiscal.

18. A aplicação dos recursos públicos também reside nos aspectos intrínsecos à natureza humana, e na busca da satisfação dos desejos pessoais, dentre eles a manutenção de poder e o acúmulo de riquezas, sem se importarem com o destino dos demais, que deveria encontrar o limite na lei, segundo entendemos encontra.

19. A atuação do Poder Judiciário deve ser conforme a Constituição Federal, a previsão de prioridades em atender os direitos fundamentais de primeira e segunda geração deve ser respeitada, essa prescrição normativa é verdadeiro axioma para elaboração dos conteúdos de programas do governo (PPA- LDO - LO), ainda em relação à realização das despesas públicas, é cogente a aplicação do princípio da eficiência.

20. A simples afirmação de inexistência de recursos, destituída de conteúdo probatório (peça orçamentária e julgamento das contas do ente político) não é por si só argumento suficiente a motivar a negativa pelo Poder Judiciário da concessão de direitos prestacionais.

21. A fruição dos direitos fundamentais de primeira e segunda geração, encontram-se limitados pela ponderação que há, necessariamente, que ser feita pelo Poder Judiciário, em cada caso concreto se a concessão daquele direito demandado individualmente ou coletivamente, implicará na impossibilidade da manutenção da fruição dos direitos e garantias fundamentais da coletividade, pois ao Estado cabe zelar pelo atendimento das necessidades de toda a coletividade, sob pena de se ferir o princípio da igualdade, corolário de nosso sistema. 


\section{REFERÊNCIAS}

ALEXY, Robert. Teoria dos direitos fundamentais. São Paulo: Malheiros Editores, 2008.

ALLIX , Edgar. Traité Élementaire de Sciences des Fianances et de Legislação Financiere Francaise. $6^{\mathrm{a}}$ ed. Paris, 1931, p. 450. In Uma introdução à ciência das finanças. $12^{\mathrm{a}}$ ed. Rio de Janeiro, Forense, 1978.

ARAGÃO, Alexandre Santos de. O princípio da eficiência. Boletim de Direito Administrativo. São Paulo, Editora NDJ, nº 03, p. 320, mar.2005.

ÁVILA, Humberto Bergmann. Sistema Constitucional Tributário. $3^{\mathrm{a}}$. ed. São Paulo: Saraiva, 2008. p. 414. v.1.

. Teoria dos Princípios da definição à aplicação dos princípios jurídicos. $4^{\mathrm{a}} \mathrm{ed}$. São Paulo: Malheiros, 2004.

. Teoria dos Princípios - da definição à aplicação dos princípios jurídicos. $5^{\mathrm{a}}$ ed. São Paulo: Malheiros, 2006.

BALEEIRO, Aliomar. Uma introdução à ciência das finanças. $12^{\mathrm{a}}$ ed. Rio de Janeiro, Forense, 1978.

BANDEIRA DE MELLO, Celso Antonio. Curso de direito administrativo. 24a ed. São Paulo: Malheiros, 1993.

Curso de direito administrativo. $6^{\text {a }}$ ed. São Paulo: Malheiros, 1995.

BATISTA JÚNIOR, Onofre Alves. O Estado Democrático de Direito Pós-Providência Brasileira em busca da eficiência pública e de uma administração pública mais Democrática. Revista Brasileira de Estudos Políticos, Faculdade de Direito da UFMG, Belo Horizonte, $\mathrm{n}^{\circ}$ 98, p. 134, jul./dez.2008.

BAUMAN, Zigmunt. Amor líquido. Rio de Janeiro: Zahar,2011.

BECKER, Alfredo Augusto. Teoria Geral do Direito Tributário. São Paulo: Saraiva, 1953. p. 102-103. 
BEREIJO, Alvaro Rodrigues. Introduccion Al Estudio Del Derecho Financiero. Madrid: Instituto de Estudios Fiscales, 1976.

BONAVIDES, Paulo. Curso de direito constitucional. $7^{\mathrm{a}}$ ed. São Paulo. Malheiros, 1997.

BORGES, José Souto Maior. Introdução ao direito financeiro. $2^{a}$. ed. São Paulo: Max Limonad, 1998.

BROCHIER-TRABATONI. Economie Financiere. pp.508-509. In SILVA, José Afonso da. Orçamento Programa no Brasil. São Paulo: Revista dos Tribunais, 1973.

BUCCI, Maria Paula Dallari. As políticas públicas e o Direito Administrativo. Revista Trimestral de Direito Público. São Paulo, Malheiros, n. 13, p. 140, 1996.

BUJANDA, SAINZ F. La elaboracion corporativa de las disciplinas financieras. Revista de Derecho Financiero y Hacienda Pública, no 70, p. 625-626. In BEREIJO, Alvaro Rodrigues. Introduccion Al Estudio Del Derecho Financiero. Madrid: Instituto de Estudios Fiscales, 1976.

CANARIS, Claus-Wilhelm. Fúnción, estructura y falsación de las teorías jurídica. Daniela Brückner, José Luiz de Castro (Trads). Madrid: Civitas, 1995.

CANOTILHO, Jose Joaquim Gomes. Direito Constitucional e Teoria da Constituição. Coimbra: Almedina, 2001.

CARRAZZA, Roque Antônio. Curso de direito constitucional tributário. 25a . ed. São Paulo: Malheiros, 2009.

CARVALHO, Kildare Gonçalves. Técnica Legislativa. 2a ed. Belo Horizonte: Del Rey, 2001.

CARVAlHO, Paulo de Barros. Curso de direito tributário. 21 a . ed. São Paulo: Saraiva, 2009.

CEREIJIDO, Juliano Henrique da Cruz. O Princípio Constitucional da Eficiência, um Enfoque Doutrinário e Multidisciplinar. Revista do Tribunal da União, Brasília, Fórum Administrativo, p. 240, mai/2001. 
CHAYES,Abram. The role of the judge in public law litigation. Harvard Law Review, n 7 , v. 89, 1976.

CHIAVENATO, Idalberto. Introdução à teoria da administração. $4^{\mathrm{a}}$ ed. São Paulo: Makron Books, 1993.

CONTI, José Mauricio. Não falta dinheiro à administração pública, falta gestão. Matéria do Consultor Jurídico, 31/12/2012. Disponível em < http://www.conjur.com.br/2012-jul31/contas-vista-nao-falta-dinheiro-administracao-publica-falta-gestao $>$. Acesso em 28/12/2013.

CORREIA NETO, Celso de Barros. Orçamento público: uma visão analítica. São Paulo, II Prêmio SOF de Monografias, 2008. Disponível em <http://www.esaf.fazenda.gov.br/premios/premios-1/premios/vii-premio-sof-demonografias/2o-premio-sof-2008/tema-2-3o-lugar/at_download/file>. p. 28-29. Acesso em $10 / 10 / 2012$.

COSTA, Regina Helena. Praticabilidade e Justiça Tributária. Sao Paulo: Malheiros, 2007.

DUARTE, Janete et al. Os determinantes da Eficiência dos Estados no Gasto Público de Saúde. Textos Para Discussão do Tesouro Nacional. Local: Editora, nº 9, p. 06, 2012.

DUGUIT, Leon. El pragmatismo jurídico. Agustín de Lázaro Álvarez, Santiago Magariños Torres, Tomás Díaz García e Miguel López-Roberts y de Chávarri (Trads).Madrid: Francisco Beltrán, 1924

FALCÃO, Amílcar de Araújo. Fato gerador da obrigação tributária. Sao Paulo: Saraiva, 2001.

FAURE, Amparo Navarro. Los principios presupuestarios a la luz de la estabilidad presupuestaria. Revista española de Derecho Financiero. Thonson Civitas. Ediciones Sevilla, p. 507, 2003.

FERRAZ JÚNIOR, Tércio Sampaio. Revista dos Mestrandos em Direito da UFBA. Salvador, no 2, pp. 65-74, jul/91-jun/92.

Ética administrativa num país em desenvolvimento. Portal de e-governo, inclusão digital $\mathrm{e}$ sociedade do conhecimento. Disponível em 
<http://www.egov.ufsc.br/portal/sites/default/files/anexos/19169-19170-1-PB.html>. Acesso em $28 / 11 / 2013$

FIGUEIREDO, Lúcia Valle. Curso de direito administrativo. $7^{\text {a }}$. ed. São Paulo: Malheiros Ed., 2004.

FONROUGE, Carlos M. Giuliani. Derecho Financeiro. $2^{\mathrm{a}}$ ed. Buenos Aires: Ediciones Depalma, 1970. p. 125. v. 1. In SILVA, José Afonso da. Orçamento Programa no Brasil. São Paulo: Revista dos Tribunais, 1973.

FOUCAULT, Michel. Nascimento da Biopolítica: curso no Collège de France (1978-1979). São Paulo: Martins Fontes, 2008.

. Em Defesa da Sociedade. São Paulo: Martins Fontes, 1999.

p.15.

A Ordem do Discurso. Aula ministrada em 02/12/1970. São Paulo: Loyola, 1996.

História da Sexualidade 1: A Vontade de Saber. Rio de Janeiro: Graal, 1988.

GALDINO, Flávio. Introdução à Teoria dos Custos dos Direitos: direitos não nascem em árvores. Rio de Janeiro: Lumen Juris, 2005.

GARCIA, Enrique Alonso. La Interpretacion de La Constitucion Madrid: Centro de Estudios Constitucionales, 1984.

GASPARINI, Diógenes.Curso de Direito Administrativo. Sao Paulo: Saraiva, 1999.

GOLDSCHIDT, Fábio Brun; VELLOSO, Andrei Pitten. Principio da Eficiencia em Matéria Tributária. In MARTINS, Ives Gandra (coord.) Principio da Eficiencia em Matéria Tributária. São Paulo: Editora Revista dos Tribunais, 2006. p. 192, (Pesquisas tributárias. Nova Serie;12).

GROISMAN, Enrique. Crisis e actualidad del derecho administrativo econômico. Revista de Derecho industrial, vol.42. p. 89. In ARAGÃO, Alexandre Santos de. O princípio da eficiência. Boletim de Direito Administrativo, São Paulo, NDJ, nº 03, p. 320, mar. 2005. p. 320 . 
HABERMAS, J.; HÄBERLE, P. Sobre a legitimação pelos direitos humanos. In: MERLE, J.; MOREIRA, L.(Org). Direito e legitimidade. São Paulo: Landy, 2003.

HAVERMAN, Robert Henry. The Economics of the Public Sector.página 169.In SILVA, José Afonso da. Orçamento Programa no Brasil. São Paulo: Revista dos Tribunais, 1973.

JÈZE, Gastón. Cours Élémentaire des Science des Finances. Paris: V. Giard \& E. Brière, 1909. p. 372. Livro II.

JHERING, Rudolf von. A finalidade no direito. In:MORRIS, Clarence (Org.). Os grandes filósofos do Direito. Trad. Reinaldo Guarany. São Paulo: Martins Fontes,.., 2002. p. 417.

JUDT,Tony. O mal ronda a Terra. São Paulo: Objetiva, 2011.

KANT , Emmanuel. Crítica da Razão Pura. J. Rodrigues de Merege (Trad.). Disponível em <http://br.egroups.com/group/acropolis/>. Acesso em: 15/07/2011

LARENZ, Karl. Metodologia da Ciência do Direito. $3^{\text {a }}$ ed. Lisboa: Fundação Calouste Gulbekian, 1997.

LUHMANN, Niklas. Conhecimento como construção. In: NEVES, C.B.; SAMIOS, E.M.B. Nova teoria dos sistemas. Porto Alegre: Ed. da Universidade/Goethe Institut, 1997.

MACHADO, Misabel Abreu et al. A elisão tributária e a lei complementar $n^{\circ}$ 104/01. In ROCHA, Valdir Oliveira (coord). O planejamento tributário e a lei complementar 101/01. São Paulo: Dialética, 2001.

MARINS, James . Direito Processual Tributário Brasileiro: Administrativo e Judicial. $4^{\text {a }}$. ed. São Paulo: Dialética, 2005.

MARMELSTEIN, George. Curso de direitos fundamentais. São Paulo: Atlas, 2008.

MARTINS, Ives Gandra da Silva. Princípio da eficiência em matéria tributária. São Paulo: Revista dos Tribunais, 2006. p. 31. (Pesquisas Tributárias. Nova série - n. 12). 
MCMULLIN, Erman. Racionality and paradigm change. In: CURD, Martin, COVER, J.. A. Philosophy of science. NewW. W. Norton,1998,

MEDAUAR, Odete. Direito administrativo moderno. 5ª ed. São Paulo: RT, 2001.

Controle da Administração Pública. São Paulo: RT, 1993.

MEIRELLES, Hely Lopes. Direito administrativo brasileiro. 16ª ed. São Paulo: Malheiros, 1991. p. 78.

MENDES, Gilmar Ferreira. Questões fundamentais de técnica legislativa apud Cláudia F. Rivera Bohn et alii. Elementos de Técnica Legislativa: teoria e prática. Porto Alegre: Sérgio A. Fabris Editor, 1999.

MODESTO, Paulo. Notas para um debate sobre o princípio da eficiência. Revista Eletrônica de Direito Administrativo e Econômico, Salvador, $n^{\circ}$ 10, maio/jun./jul.2007. Disponível em $<$ http://www.direitodoestado.com/revista/REDAE-10-MAIO-2007-

PAULO\%20MODESTO.pdf >. Acesso em 20/10/2012

MONCADA, Cabral de. Direito público e eficácia. Lisboa: Pedro Ferreira, 1997.

MORAND, Charles-Albert. Le droit Neo-Moderne des Politiques Publiques. Paris: LGDJ, 1999.

MORIN, Edgar. O Método 6 - ÉTICA. Juremir Machado da Silva (Trad.). Porto Alegre:Sulina, 2011

NABAIS, José Casalta. O dever fundamental de pagar impostos. Coimbra: Almedina, 1998.

NOBRE, Edilson Pereira Júnior. Administração Pública e o Princípio Constitucional da Eficiência. Revista Trimestral de Direito Público, São Paulo: Malheiros, nº.44, p. 75, 2003.

OLIVEIRA, Regis Fernandes de. Curso de Direito Financeiro. São Paulo: Revista dos Tribunais, 2011.

Curso de direito financeiro. $3^{a}$ ed. rev.e atualizada. São Paulo: Editora Revista dos Tribunais, 2010. 
PERELMAN, C. Ética e Direito. Maria Ermantina Galvão (Trad). São Paulo: Martins Fontes, 1996.

PUGLIESE, M. Istituioni di Diritto finanziario. Diritto tributário Cedam, Padova,1932. p.6-7. In BEREIJO, Alvaro Rodrigues. Introduccion Al Estudio Del Derecho Financiero. Madrid: Instituto de Estudios Fiscales, 1976.

ROSS, Alf. Teoria de las fuentes del derecho: una contribución a la teoría del derecho positivo sobre la base de investigaciones histórico-dogmáticas. José Luis Muñoz de Baena Simón, Aurelio de Prada Garcia, Pablo López Pietsch (Trads).Madrid: Centro de Estudios Políticos y Constitucionales, 1999.

ROTHMANN, Gerd Willi. O princípio da legalidade tributária. In Direito Tributário. São Paulo: Editora, 1973. p.154 e ss. (5 Coletânea)

SANO E FILHO, Hironobu; MONTENEGRO, Mário Jorge França. As técnicas de avaliação da eficiência, eficácia e efetividade na gestão pública e sua relevância para o desenvolvimento social e das ações públicas. Desenvolvimento em Questão: Unijuí , ano 11, n. 22, p. 39, 2013.

SANTI, Eurico Diniz de. Segurança jurídica demanda mudança de atitude de auditores. Matéria no Consultor Jurídico. Disponível em <http://www.conjur.com.br/2013-out10/eurico-santi-seguranca-juridica-demanda-mudanca-atitude-auditores $\rangle$. Acesso em $12 / 12 / 2013$.

SARLET, Ingo Wolfgang. A eficácia dos direitos fundamentais. $6^{\text {a }}$. ed. PortoAlegre: Livraria dos Advogados, 2006.

SCHOUERI, Luis Eduardo. Direito Tributário. São Paulo: Saraiva,2011.

SEN, Amartya. Desenvolvimento como liberdade. Local: Companhia de Bolso, 2010.

SILVA, José Afonso da. Curso de direito constitucional positivo. São Paulo: Malheiros, 2006.

Orçamento Programa no Brasil. São Paulo: Revista dos Tribunais, 1973. 
SILVA, Virgilio Afonso da. O proporcional e o razoável. Revista dos Tribunais, São Paulo, 798, p. 40, 2002.

SMITH, Adam. Riqueza das Nações. Norberto de Paula Lima (Trad.) ed. cond. São Paulo : Folha de São Paulo, 2010. p.347. (Coleção Folha: Livros que mudaram o mundo. v.4).

SOUZA, Celina . Políticas Públicas uma revisão de literatura. Revista Sociologias, Porto Alegre, ano 8, nº 16, p. 36, jul/dez 2006.

TATE, Neal; VALLINDER, Torbjorn. The global expansion of judicial power: the judicialization of politics. New York, New York University Press, 1995. In CASTRO, Marcos Faro de. O Supremo Tribunal Federal e a Judicialização da Política. Revista Brasileira de Ciências Sociais, 12, 34, p. 148, 1997.

TEORIA da norma jurídica. Disponível

em <http://www.terciosampaioferrazjr.com.br/?q=/publicacoes-cientificas/13>. Acesso em $11 / 10 / 2012$.

TIMM, Luciano Benetti. Qual a maneira mais eficiente de prover os direitos fundamentais: uma perspectiva de direito e economia? In: SARLET, Ingo Wolfgang; TIMM, Luciano Benetti Organizadores). Direitos Fundamentais, Orçamento e Reserva do Possível. Porto Alegre: Livraria do Advogado, 2008.

TORRES, Ricardo Lobo. Legalidade tributária e riscos sociais. Revista Dialética de Direito Tributário, São Paulo, n. 59, p. 100-101, ago.2000.

.Normas de Interpretação e Integração do Direito Tributário. Rio de Janeiro, Forense, 1994.

TRINDADE, José Maria Arruda. Legalidade tributária, segurança jurídica, pós-positivismo e a difícil relação entre política e direito. THESIS, São Paulo, ano III, v. 5, p. 58-96, $1^{\circ}$ sem. 2006.

VIDIGAL, Geraldo de Camargo. Fundamentos do direito financeiro .São Paulo: Revista dos Tribunais, 1973.

VIEHWEG, Theodor. Tpoia e Giurisorudenza. Milão: Giuffré, 1962. 